$$
\text { Universidade de São Paulo }
$$

Faculdade de Filosofia, Letras e Ciências Humanas

Departamento de História

Programa de Pós Graduação em História Social

REGINA KÁTIA RICO SANTOS DE MENDONÇA

\author{
ESCRAVIDÃO INDÍGENA \\ NO VALE DO PARAÍBA
}

exploração e conquista dos sertões da capitania de

Nossa Senhora da Conceição de Itanhaém, século XVII 
Universidade de São Paulo

Faculdade de Filosofia, Letras e Ciências Humanas

Departamento de História

Programa de Pós Graduação em História Social

\title{
ESCRAVIDÃO INDÍGENA \\ NO VALE DO PARAÍBA \\ exploração e conquista dos sertões da capitania de \\ Nossa Senhora da Conceição de Itanhaém, século XVII
}

\author{
REGINA KÁTIA RICO SANTOS DE MENDONÇA \\ Dissertação apresentada ao Programa de Pós \\ Graduação em História Social do Departamento de \\ História da Faculdade de Filosofia, Letras e Ciências \\ Humanas da Universidade de São Paulo, para \\ obtenção do Título de Mestre em História
}

Orientador: Prof. Dr. Pedro Puntoni

São Paulo

2009 
Às nações indígenas que viveram e deixaram sua história no Vale do Paraíba. 


\section{AGRADECIMENTOS}

A produção desta dissertação de mestrado depreendeu um esforço e aprendizado que não teriam sido possíveis sem a colaboração do Prof. Dr. Pedro Puntoni, meu querido orientador. Companheiro desde a primeira hora, contribuiu, acreditou, apoiou e cobrou sempre com a dedicação e a seriedade necessárias para o desenvolvimento correto, tanto do trabalho quanto da orientanda. Espero que o resultado da empreitada te honre, tanto quanto me honrou sua orientação.

Nesse processo, devo muito às Professoras Doutoras Íris Kantor e Vera Lúcia Amaral Ferlini que compuseram a minha banca de qualificação. A leitura crítica e as observações que fizeram deram novos rumos ao trabalho. Agradeço também a $\operatorname{Prof}^{a} \operatorname{Dr}^{a}$ Laura de Mello e Souza pela indicação acertada do orientador, pelo carinho dedicado para com sua aluna.

Aos funcionários e amigos da Cátedra Jaime Cortesão pela colaboração e auxílio na elaboração deste trabalho.

Ao ex-governador do estado de São Paulo Dr. Geraldo Alckmin pela bolsa de estudos concedida via CAPES e por todos os profissionais da Secretaria da Educação de São Paulo, em especial os queridos amigos da Diretoria de Ensino de Taubaté que muito me apoiaram para a conclusão deste trabalho.

Ao meu ex Prof ${ }^{\circ}$. Dr. Maurício Martins Alves. Exemplo de amizade e profissionalismo e a quem agradeço o apoio constante.

Pelo exemplo de vida, por me ajudar a compreender o caminho certo na área da pesquisa voltada aos estudos indígenas à antropóloga $\operatorname{Prof}^{\mathrm{a}}$. $\mathrm{Dr}^{\mathrm{a}}$. Rita Amaral.

Ao frei Róger Brunorio, OFM, Convento Santo Antonio, Arquidiocese de São Sebastião do Rio de Janeiro, pelo apoio às pesquisas relacionadas ao Convento Santa Clara de Taubaté.

Aos meus amigos professores e funcionários que apoiaram e ficaram na torcida da E.E Dr.Flair Carlos de Oliveira Armany o meu muito obrigado e também aos amigos e funcionários do Arquivo Histórico de Taubaté agradeço de coração pela dedicação com que me auxiliaram. 
Aos jovens Tonni Fagner Rodrigues da Cruz (aluno de Arquitetura na UNITAU) e Vagner de Oliveira Félix pela amizade e apoio na montagem do trabalho.

À todos amigos que direta ou indiretamente sempre estiveram presente nesta caminhada o meu muito obrigado pela força e aprendizado durante a amizade construída.

Ao querido esposo Joaquim e filhos amados Lucas e Nicolas que sempre foram meus pilares. 


\title{
RESUMO
}

O objetivo desta dissertação é refletir, analisar e apreender o sistema que envolveu o trabalho compulsório indígena na região do Vale do Paraíba Paulista, enfocando os sertões de Taubaté, no século XVII (período em que os espaços fronteiriços se alargam com o movimento das "bandeiras paulistas de apresamento e mineração"). Neste contexto surgem novas vilas e povoados (locais de abastecimento) ligando a região de São Paulo - Vale do Paraíba - Minas Gerais - Rio de Janeiro (via Parati) e o extermínio e escravidão de várias nações indígenas. Existem lacunas sobre o cotidiano dos colonos, religiosos e indígenas destas vilas. Os processos históricos e seus agentes serão estudados através de inventários, testamentos,cartas de alforrias, documentos diversos do Convento de Santa Clara referente ao período seiscentistas da vila de Taubaté, também serão pesquisados Atas da Câmara de Taubaté, Mapas e fontes secundárias que enriqueçam a pesquisa em questão.

Palavras-chave: Escravidão, Índios, Vale do Paraíba, Bandeiras paulistas de apresamento, Brasil Colonial

\begin{abstract}
The aim of this essay is to reflect, analise and understand the sistem which involved the mandatory indian work in the region of the Vale do Paraíba Paulista, focusing the backwoods of Taubate, on the XVII century(period in which the boundaries expand with the moving of the "paulistas flags of arrest and mining"). In this context, many towns and villages (stock places) appeared, connecting the region of "São Paulo - Vale do Paraíba - Minas Gerais - Rio de Janeiro (via Parati)" and the extermination and slavery of many indian tribes. There are many gaps about the daily life of the settlers, religious people, and indians of these places. Most of the historic process and their principal agents will be studied by inventories, wills, letters of manumission, several documents from the "Santa Clara" Monastery concerning the six hundredth period in the village of Taubaté, will also be discussed, as well as the "Minutes of the Board of Taubaté, maps and secondary sources that enrich the research in question.
\end{abstract}

Keywords: Slavery, Indians, Vale do Paraíba, Paulistas flags of arrest, Colonial Brazil 


\section{ABREVIATURAS}

\section{ARQUIVOS}

AHU Arquivo Histórico Ultramarino. Lisboa

DMPAH Divisão de Museus, Patrimônio e Arquivo Histórico Taubaté

\section{COLEÇÕES DE DOCUMENTOS IMPRESSOS E PERIÓDICOS}

ACSP Atas da Câmara da Vila de São Paulo.São Paulo

ACT Atas da Câmara da Vila de Taubaté. Taubaté

AESP-INP Arquivo do Estado de São Paulo - Inventários não publicados

RAM Revista do Arquivo Municipal de São Paulo. São Paulo

RIEB Revista do Instituto de Estudos Brasileiros

RIHGSP Revista do Instituto Histórico e Geográfico de São Paulo. São Paulo

RIHGB Revista do Instituto Histórico e Geográfico Brasileiro 
CAPÍtTULO 1.

SÃO PAULO DE PIRATININGA: O COTIDIANO NO SÉCULO XVII

1.1 São Paulo de Piratininga: a vila 14

1.2. conflitos e tensões sociais entre brancos e indígenas 18

1.3. Jesuítas: uma visão oposta dos colonos vicentinos 30

\section{CAPÍTULO 2.}

O SERTÃO: SOLUÇÃO PARA A "POBREZA DOS PAULISTAS"

2.1. Criar e recriar caminhos para o sertão

2.2. A criação de uma força de trabalho no sertão: "a cura para sua pobreza"

\section{CAPÍTULO 3.}

A TRANSFORMAÇÃO DOS SERTÕES DO VALE DO PARAÍBA

3.1. Os primeiros habitantes do Vale do Paraíba $\quad 56$

3.2. A Vila de São Francisco das Chagas de Taubaté 61

3.3. O Convento de Santa Clara : converter os "gentios da terra" e fortalecer a fé dos colonos taubateanos

3.4. Os cativos indígenas dos colonos de Taubaté no período de 1640 a 1699

3.5. Cultura de subsistência? 


\section{INTRODUÇÃ O}

Quando questionamos sobre a origem, costumes, conflitos, trabalho, comércio, relações sociais que existiram na região dos sertões do Vale do Paraíba deparamos com confusas "deduções". Uma delas que insiste em misturar o mito bandeirante paulista com o sertanista contratado ou autônomo que busca no sertão prestígio e poder aprisionando cativos de várias nações e sonhando com o ouro e a prata que poderia enriquecê-lo rapidamente; outra a visão de que somente os religiosos jesuítas influenciaram na formação religiosa dos nativos ocultando outras ordens como carmelitas e franciscanos que se envolveram nas incursões paulistas a procura de cativos para seus conventos; outra a denominação das nações indígenas generalizando como "Carijós" ,"Guaianás", "Tupis", "Tapuias", seguindo relatos de viajantes que assim o denominaram. Existem lacunas sobre o cotidiano desses colonos, religiosos, indígenas. Sabe-se pouco da história indígena : nem a origem, nem as cifras de população são seguras. ${ }^{1}$ Apesar de possuir vários documentos deixados em inventários e testamentos , muito pouco foi escrito sobre os indígenas do Vale do Paraíba e seu relacionamento com os colonos e religiosos que conviveram. Preencher estas lacunas é o nosso interesse principal.

Assim a pesquisa visa refletir, analisar e apreender o sistema que envolveu o trabalho compulsório indígena na região do Vale do Paraíba Paulista, enfocando os sertões de Taubaté, no século XVII (período em que os espaços fronteiriços se alargam com o movimento das "bandeiras paulistas de apresamento e mineração"). Neste contexto surgem novas vilas e povoados como locais de abastecimento ligando São Paulo - Vale do Paraíba - Região Mineradora, bem como o comércio entre o Vale e o litoral do Rio de Janeiro (via Parati). São estes caminhos da "trilha dos índios" que as incursões de apresamento indígena se desenvolvem escravizando "peças do gentio da terra" e exterminando várias nações indígenas. Diferentemente do século XVI, quando em contato com os grupos tupis da costa e no contexto de afirmação do domínio, estas guerras (justas) objetivavam o extermínio total e não a integração ou submissão. Os tapuias eram tomados por ampla e duradoura muralha que se erguia no sertão, obstando a expansão do Império e a propagação da "verdadeira fé", como empecilho ao

\footnotetext{
${ }^{1}$ Manuela Carneiro da Cunha. História dos índios no Brasil, p.11
} 
desenvolvimento da economia pastoril e à exploração dos minérios. ${ }^{2} \mathrm{~A}$ visão de Pedro Puntoni sobre a região nordeste pode ser também comparada a região sudeste do Brasil em especial o Vale do Paraíba Paulista, onde o relevo destaca as serras do Mar e da Mantiqueira (Sabarabuçu para os indígenas) favorecendo a "segurança" natural das nações indígenas que procuraram nos sertões o abrigo longe do conquistador europeu. Vale ressaltar que durante a análise da pesquisa procuramos não construir uma história-revanche mas reescrever a história do Vale do Paraíba num contexto de inter-relações entre a cultura indígena e outras culturas ligadas a exploração dos sertões pelos religiosos e sertanistas paulistas.

Alguns dos principais documentos analisados foram os inventários e testamentos seiscentistas, Registro de Batismos de 1686, Cartas de Alforria de 1698 envolvendo negros da terra do Arquivo Histórico de Taubaté. Além disso, vimos também As Atas da Câmara da vila de Taubaté do período de 1780 a 1798 (Não há registros anteriores a este período), a documentação do Arquivo da Arquidiocese de São Sebastião do Rio de Janeiro da Fraternidade Franciscana de Santo Antonio - Província da Imaculada Conceição. Também foram analisados a documentação localizada no Arquivo Histórico Ultramarino, a partir dos catálogos do Projeto Resgate "Barão do Rio Branco" no que se refere a Capitania de São Vicente e Capitania de São Paulo.

A pesquisa se divide em três capítulos. No primeiro refletiremos sobre o cotidiano no final do século XVI e início do XVII entre indígenas, religiosos e colonos do Planalto de Piratininga. Estes relacionamentos serão importantes na formação das entradas e bandeiras de apresamento em direção aos sertões do Vale do Paraíba. ${ }^{3} \mathrm{O}$ segundo, estudará os caminhos para o sertão como "remédio para a pobreza do paulista", a reorganização do apresamento originando a formação dos povoados e vilas na região do Vale do Paraíba. ${ }^{4} \mathrm{O}$ terceiro, a transformação dos sertões do Vale do Paraíba Paulista, a origem da Capitania de Nossa Senhora da Conceição de Itanhaém, o nascimento da vila de Taubaté, a influência dos religiosos franciscanos, as atividades econômicas e sua relação com o trabalho

2 Pedro Puntoni A Guerra dos Bárbaros: povos indígenas e a colonização do sertão nordeste do Brasil,1650-1720, p.17

${ }^{3}$ Fernando A. Novais .Colonização e sistema colonial: discussão de conceitos e perspectiva histórica, em Anais do IV Simpósio Nacional dos Professores Universitários de História, p.253. Caio Prado Jr. O Sentido da Colonização, em Formação do Brasil Contemporâneo.2004.

4 John M. Monteiro. Negros da Terra.Índios e bandeirantes nas origens de São Paulo, 1994 e Sérgio Buarque de Holanda. Caminhos e Fronteiras,1994. 
compulsório indígena voltada para a ligação com o planalto paulista, a região mineradora dos Cataguás e o "caminho velho" via Rio de Janeiro (Parati). Neste contexto, além de Caio Prado ter falado da dinâmica de um mercado interno,Ilana Blaj analisa vários autores que apontam para uma produção local que ultrapassa o mero nível do autoconsumo e de uma economia de subsistência. ${ }^{5}$.

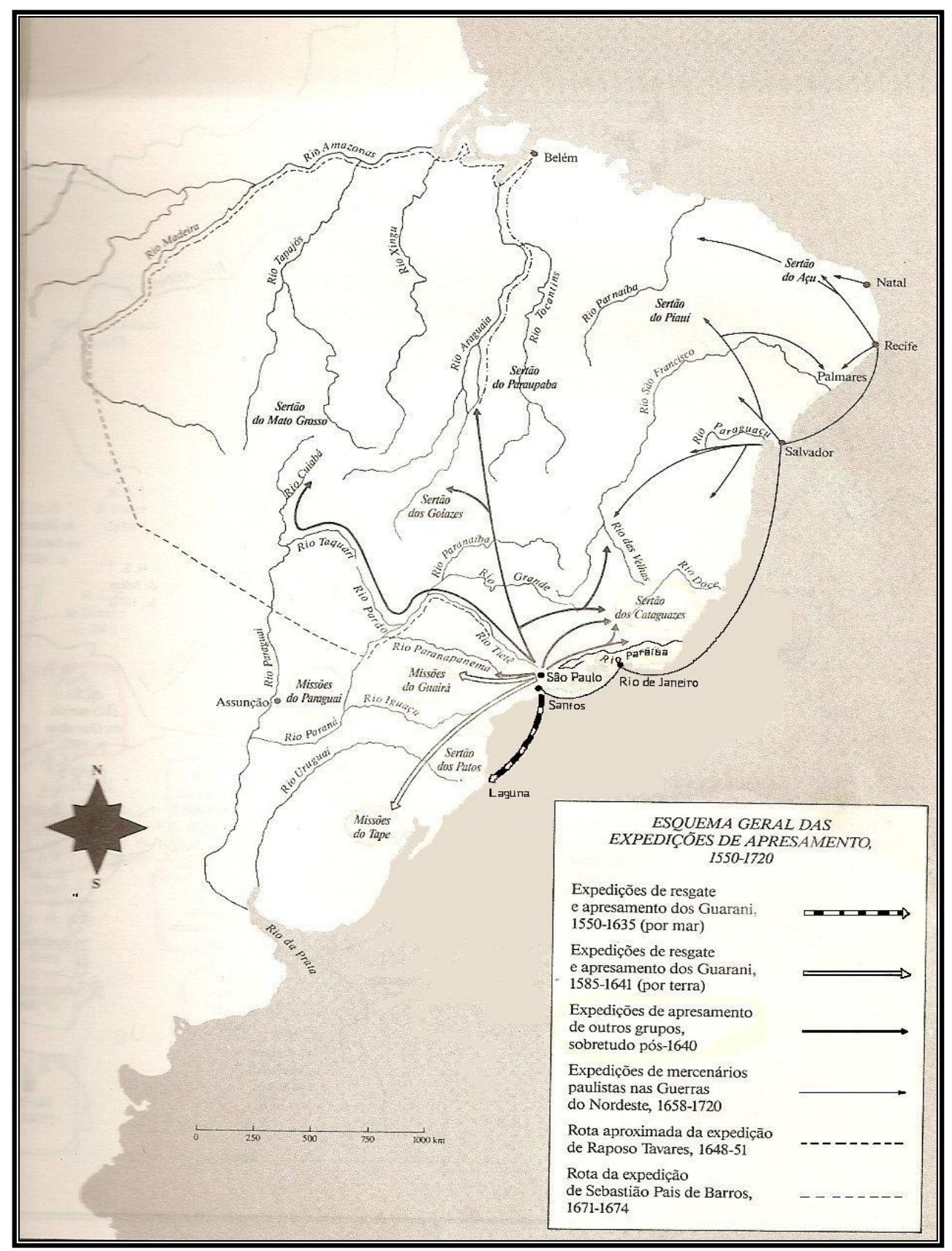

Esquema geral das expedições de apresamento (1550-1720)

FONTE: John M. Monteiro, Negros da terra, p.13

5 Caio Prado Jr. Agricultura de subsistência, op.cit. Atividades acessórias, História Econômica do Brasil, 1983 e Ilana Blaj. A trama das tensões: o processo de mercantilização de São Paulo Colonial (1681-1721), São Paulo , Humanitas, 2002, p.96. 


\section{CAPÍTULO 1 \\ SÃO PAULO DE PIRATININGA: O \\ COTIDIANO NO SÉCULO XVII}

Fins do século XVI e com ele terminavam as vacilações, o medo das rebeliões indígenas, ao longo da costa, quase toda ocupada, mas muito pouco povoada. Tinha-se passado todo um século de lutas entre a resistência do gentio, a surpresa dos corsários e a dificuldade em adaptar-se ao clima tropical da nova terra. Formaram-se nesse período laços entre o conquistador europeu e o nativo indígena através do escambo e dos matrimônios que reforçavam a estrutura portuguesa na Colônia.

O sertão, depois de várias entradas realizadas pelos paulistas [muitas delas sem sucesso] era tomado de encantamento e mistérios onde as lendas contadas pelos nativos, "gentio da terra", transformavam o conquistador europeu pelo fascínio de descobrir riquezas minerais e apresar índios para suas lavouras [pois a mão-de-obra africana possuía um valor muito alto]. É no sertão que o paulista encontrará "o remédio para sua pobreza", a solução para ganhar prestígio e poder. As muralhas para o colono da beira-mar e do Planalto de Piratininga deixam de ser obstáculo e passa a ser desafio, o paulista se prepara, articula milícias, estuda caminhos e penetra os sertões.

A Coroa portuguesa por sua vez apóia e incentiva os colonos, pois tinha seus próprios interesses, fiscais e estratégicos acima de tudo: queria ver prosperar a Colônia, mas queria também garantí-la politicamente. Para tanto, interessavam-lhe aliados índios nas suas lutas com franceses, holandeses e espanhóis, seus competidores internos, enquanto para garantir seus limites externos desejava "fronteiras vivas", formadas por grupos indígenas aliados. ${ }^{1}$

Reforçando os interesses da Coroa, o governador do Brasil entre 1591 e 1601, D. Francisco de Sousa intensificou as incursões portuguesas ao sertão, dedicando-se totalmente à busca de metais e pedras preciosas, acreditando nas lendas indígenas de uma serra resplandecente que se localizava nas cabeceiras do rio São Francisco. Seu projeto acima de tudo era articular os setores de mineração, agricultura e indústria, todos sustentados por uma sólida base de trabalhadores indígenas, talvez inspirado

1 Nádia Farage, As muralhas dos sertões : os povos indígenas no rio Branco e a colonização, 1991. 
no modelo da conquista da América Espanhola, porém nas terras da América Portuguesa não deu certo. Embora seu projeto fracassado na tentativa de transformar o sertão em um dinâmico e movimentado núcleo europeu, surtiu efeito na organização da economia local de São Paulo, favorecendo o crescimento da lavoura comercial e estimulando o apresamento indígena na própria capitania de São Vicente. Conforme Alvará do rei D.João IV, de 10 de Junho de 1644, para o superintendente geral das Minas do Brasil, Salvador Correia de Sá e Benevides, "é ordenado que minas de ouro e prata, já descobertas ou as por descobrir, passem a ser propriedade dos vassalos que as achem, desde que paguem os devidos quintos e se submetam ao Regimento passado [ao responsável citado,o superintendente geral das Minas do Brasil], para administrar às Minas de São Paulo e São Vicente.E, por este Regimento, as pessoas que descubram minas devem se apresentar ao provedor delas para registrar sua descoberta, procedendo à exploração às suas custas no prazo de 30 dias, devem demonstrar o metal achado". ${ }^{2}$ E seguindo o Regimento dado pelo rei D.João IV, o monarca manda:

(...) que para o trabalho das mesmas minas se possa servir dos índios de qualquer aldeia, pagando-lhes os seus salários. Diz ainda que, tendo sido informado de não só em São Paulo, mas também em outras partes do Brasil, haver minas de ouro, prata, ferro, cobre, calaim, pérolas e esmeraldas, o encarrega de tomar informações delas e procurar descobri-las. Mande que agracie com honras, mercês todas as pessoas que descobrirem minas, para assim as estimular. Recomenda particular cuidado com o descaminho do que pertencer aquela Fazenda. (...) Diz que só em São Paulo se construa uma Casa da Moeda, com os oficiais necessários. ${ }^{3}$

Mesmo a Coroa proibindo o cativeiro indígena, os colonos ignoravam alegando "guerra justa". Se a liberdade é sempre garantida aos aliados e aldeados, a escravidão é, por outro lado, o destino dos índios inimigos. Os direitos de guerra são objeto de grande elaboração, reconhecidos mesmo nos momentos em que se declara a liberdade de homens que, segundo princípios assentes de direito, seriam justamente escravizados. Nesses momentos (Leis de 1609,1680 e 1755), consideram o direito de guerra secundário diante da importância da salvação das almas, civilização ou defesa da liberdade natural dos índios, constantemente ameaçadas pelos colonos que não respeitavam às leis. As suas "justas razões de direito" para a escravização

2 Conforme Arquivo Histórico Ultramarino, a partir dos catálogos do Projeto Resgate "Barão do Rio Branco" no que se refere à Capitania de São Paulo. AHU_ACL_CU_023, Cx.1, D.3.

3 Ibidem, AHU_ACL_CU_023-01,Cx.1,D.11. Com relação as honras e mercês, ver interessante dissertação de mestrado de Jackson Fergson Costa de Farias . Honra e escravidão: um estudo de suas relações na América Portuguesa, séculos XVI-XVIII, FFLCH/USP,2008. 
dos indígenas, de que fala à Lei de 1680, são basicamente duas : a guerra justa e o resgate. ${ }^{4}$ Em seus inventários [burlando à lei] os colonos paulistas denominavam os escravos indígenas no rol de peças como: gentio da terra, peças, peças do gentio, peças do gentio da terra, peças de serviço, gente de serviço, gente fôrra, peças fôrras, negros da terra, negros do gentio da terra, fôrros, serviços fôrros, gente fôrra do gentio da terra, serviços do gentio da terra, gente de obrigação, peças de serviço fôrra, gentio fôrro, gente da terra fôrra, gentio de serviço, gentio, pessoas fôrras, peças fôrras serviçais, gente da terra, almas do gentio da terra fôrras, gente do Brasil, peças da terra, peças de administração, almas, peças de administrar. ${ }^{5} \mathrm{O}$ valor de seus serviços constam como alvidrados para que à Lei contra o cativeiro indígena não os culpasse e condenasse perante às Ordens da Coroa.

Com certeza todo este confronto gerará conflitos de interesses particulares entre os colonos e a Coroa, pois o trabalho indígena era naquele momento primordial para o desenvolvimento da Colônia. Mas um terceiro elemento complicará mais ainda a situação, a Igreja, ou mais precisamente a ordem religiosa jesuítica. É neste contexto que desenvolveremos este capítulo.

\subsection{São Paulo de Piratininga: a vila}

De acordo com Alcântara Machado a vila de São Paulo do Campo, capitania de São Vicente, partes do Brasil, não passava de um lugarejo humilde no final do século XVI. Cem anos depois, continua a ser tão pequena a povoação, já então elevada à categoria de cidade.

Às míseras choupanas de que compõe inicialmente o povoado, segundo testamentos e inventários da época vão sucedendo as construções de taipa, com exuberantes beirais e rótulas nas portas e janelas, a moda mourisca. As cobertas primitivas de palha aguarirana ou sapé cedem lugar aos telhados. Dianteiras e terreiras são quase todas as casas. Tem a casa às vezes um lanço de sobrado e meio lanço terreiro.(...) Raras são decerto, as assoalhadas de tabuado e as que tem alguma sala forrada. Pouco valem os terrenos. Vai subindo o valor com o correr dos anos. ${ }^{6}$

4 Beatriz Perrone-Moisés. Índios livres e índios escravos: os princípios da legislação indigenista do período colonial (séc.XVI a XVIII) In: Manuela Carneiro da Cunha, Historia dos Î́ndios no Brasil, p.123

5 Ernani Silva Bruno. O que revelam os inventários sobre escravos e gente de serviço. Revista do Arquivo Municipal de São Paulo, v.188,p.65

6 Alcântara Machado. Vida e morte do bandeirante,p.37-45. 
Mas são nos sítios e fazendas paulistas, ou seja na zona rural que tudo movimenta, tudo gira, a vila não se desenvolveria sem o trabalho do campo. Os mercados interno e externo dependem desta agricultura que tudo faz mover e a partir daí nasce o incentivo em buscar nos sertões braços indígenas para sua lavoura.

Do latifúndio é que parte a determinação de valores sociais; nele é que se traçam as esferas de influência; é ele que se classifica e desclassifica os homens; sem ele não há poder efetivo, autoridade real, prestígio estável. O lucro não é o único incentivo às explorações agrícolas. $\mathrm{O}$ que se procura antes de tudo é a situação social que decorre da posse de um latifúndio, as regalias que dele provém, a força, o prestígio, a respeitabilidade. ${ }^{7}$

As análises feitas por Alcântara Machado e Oliveira Vianna, mostram um quadro de São Paulo seiscentista voltada para a primazia e autosuficiência das propriedades rurais em detrimento das regiões urbanas da vila onde ela aparece como um apêndice deste dinamismo, restrito as cerimônias religiosas e algumas sessões na Câmara Municipal. Sérgio Buarque discorda alegando que a famosa auto-suficiência das propriedades rurais no Brasil colônia não passa de pobre figura de retórica. ${ }^{8}$ Ilana Blaj em seus estudos também reforça esta visão de que não havia auto-suficiência nas propriedades rurais da São Paulo colonial, mesmo quando em Atas os colonos reclamam falta de mantimentos na vila, pressionando a fixação de preços dos gêneros vendidos na região. Para ela essas reivindicações não se restringem às camadas mais desfavorecidas da população, ao contrário, nas Atas da Câmara Municipal, vê-se assinaturas de requerentes de vários "homens bons" da localidade, proprietários de lavouras e currais, que já haviam ocupado ou ocupavam cargos na administração. ${ }^{9}$

Muriel Nazzari, analisa que em meados do XVIII e comparando ao século XVII [e finais do XVI], não havia ainda a figura do proprietário estritamente urbano. Metade dos proprietários urbanos, tinham uma ou mais

7 Ibidem, p.33 Ver também p.50 onde o autor destaca que "na cidade o fazendeiro tem apenas a sua casa para descansar alguns dias, liquidar um ou outro negócio, assistir às festas civis e religiosas. Só nos dias santos é que há gente na vila e por isso mesmo são eles os escolhidos para o praceamento dos bens de órfãos." Oliveira Vianna nos fala de um processo de ruralização da população colonial, na intenção de fundamentar a hegemonia deste grupo até o período imperial, garantindo sua continuidade no período republicano.Populações meridionais do Brasil, p.26-27

8 Sergio Buarque de Holanda, Movimentos da população em São Paulo no século XVII, RIEB, n.1,p.59.

9 Ilana Blaj, A trama das tensões: o processo de mercantilização de São Paulo Colonial (1681-1721), São Paulo, Humanitas, 2002, p.120 
fazendas ou sítios, mesmo os mercadores mais prósperos. ${ }^{10}$ Diante destas reflexões entendemos que não existia uma separação entre rural e urbano, não havia dependência do urbano com relação ao rural, mas o campo e a cidade formavam um todo único, seja a nível econômico, social e político.

Não houve uma ruptura entre o rural e urbano, mesmo após encontrar as minas de ouro no final do XVII, como mostra a historiografia tradicional, nem houve um comércio específico voltado para a região mineradora. ${ }^{11} \mathrm{O}$ que verificamos é a expansão do comércio por suas lavouras, currais e crescente circulação de mercadorias, ligando a região de São Paulo ao Vale do Paraíba e a região que se explorava os minérios [os sertões dos Cataguás]. Em busca do "equilíbrio vital", São Paulo tornou-se, "mãe de outras cidades do planalto". ${ }^{12}$ Alfredo Ellis Jr. analisa a expansão da vila de São Paulo pelos vales do Paraíba e Tietê e a fundação de outras vilas, como Mogi das Cruzes (1611), Taubaté (1640), Guaratinguetá (1651), Jacareí (1653), apontando como causa determinante desse movimento o declínio do bandeirismo de apresamento que teria liberado o paulista para outras atividades. ${ }^{13}$ Porém, John Monteiro , articula a expansão da vila paulistana ao desenvolvimento da escravização indígena, onde os paulistas seriam menos dependentes dos aldeamentos próximos à vila.Para ele, na São Paulo do final do século XVI e início do XVII houve o aumento da escravidão indígena e exemplifica que entre 1600 e 1644 , segundo alguns registros, pelo menos 250 sesmarias foram concedidas, devido à triticultura, povoando-se áreas de Mogi das Cruzes, Santana de Parnaíba (1580) e territórios das futuras vilas de Jundiaí (1655), Itu (1658) e Sorocaba (1661). A direção e extensão territorial aconteceu pela necessidade do trabalho indígena e foi através da transição do trabalho dos aldeados para o trabalho escravo que definiram o papel do indígena na São Paulo Colonial do século XVII.

Além das técnicas agrícolas e da questão da mão-de-obra, o crescimento demográfico também deve ser considerado fator de peso,pois este influenciará nos padrões de assentamento dos conquistadores europeus. É certo que a população da capitania cresceu rapidamente durante a primeira metade do século XVII devido ao grande fluxo de cativos guarani

10 Muriel Nazzari, O desaparecimento do dote: mulheres, famílias e mudança social em São Paulo, Brasil, 1600-1900; tradução Lólio Lourenço de Oliveira. 2001

11 Florestan Fernandes, Caracteres rurais e urbanos na formação e desenvolvimento da cidade de São Paulo.In: Mudanças sociais no Brasil, p.206-9.

12 Richard M. Morse. Formação histórica de São Paulo de comunidade à metrópole, p.37

13 Alfredo Ellis Jr., Capítulos da história psicológica de São Paulo, Boletim FFLCH/USP, n.53,1945. 
aprisionados antes de 1640. A imigração de elementos da Metrópole como hispano-paraguaios favoreceu este crescimento onde entre 1620 e 1640 integraram-se as famílias Bueno, Camargo e Fernandes. ${ }^{14}$

Diante deste quadro,observamos que não houve uma nova configuração da vila de São Paulo no século XVII, o rural e o urbano se interligavam e se interdependiam em todas as esferas: sociais, econômicas e políticas. Não aconteceu uma ruptura brusca com o modo de vida do século passado, pelo contrário, houve a consolidação de todo um processo de expansão econômica, de mercantilização e de concentração de poder nas mãos de uma elite local. A articulação com o núcleo mineratório dinamizará este quadro mas não será responsável por sua existência. ${ }^{15}$ Os indígenas cativos ou não no que diz respeito às relações de trabalho também participaram desse processo, a disputa pela mão-de-obra indígena entre colonos e religiosos aumentará, transformando a vila paulista no centro das incursões de apresamento rumo aos sertões, devastando e despovoando aldeias em busca de novos cativos para seus plantéis, seja para abastecer suas fazendas, conventos ou suas incursões para às minas. A negligencia da Coroa Portuguesa no que diz respeito ao "não ver" o cumprimento da lei pelos paulistas [acreditando manter suas fronteiras protegidas dos ataques de inimigos interessados nas terras brasileiras], favorecerá às entradas aos sertões. A igreja não se omitirá mas estará presente na figura de seus religiosos com objetivo de levar a "fé" e "converter" os nativos pagãos. A preocupação em preservar os caminhos e criar novos, também favorecerá as articulações mercantis ligando São Paulo - Vale do Paraíba - Região Mineradora - Rio de Janeiro (via Parati), consequentemente aumentará o comércio de apresamento indígena e a fixação do conquistador europeu nos sertões ainda não conhecidos.

14 John M. Monteiro, Negros da Terra. Índios e bandeirantes nas origens de São Paulo, pág.104-107. Essas famílias disputavam o controle administrativo e político da vila de São Paulo, e se revezavam no poder, gerando conflitos entre os colonos paulistas que não aceitavam tal procedimento. Ver Carta do Provedor e Contador da Fazenda Real e Juiz da Alfândega nas Capitanias de São Vicente, Sebastião Fernandes Correia, para D. Afonso VI, avisando-o das desordens na vila de São Paulo ocasionada pelas famílias Camargo e Pires, que livram todo o criminoso que a eles se juntam. In: Arquivo Histórico Ultramarino, a partir dos catálogos do Projeto Resgate "Barão do Rio Branco" no que se refere à Capitania de São Paulo. AHU_ACL_CU_023-01, Cx.1, D.1, 4 de junho de 1657.

15Ludmila Gomide Freitas, discute bem a questão da formação desta elite local da vila de São Paulo em sua dissertação de mestrado: A Câmara Municipal da vila de São Paulo e a escravidão indígena no século XVII(1628-1696), UNICAMP,2006 


\section{2. conflitos e tensões sociais entre brancos e indígenas}

Como analisa Caio Prado Jr, qual seria o verdadeiro sentido da colonização nas terras da América Portuguesa? Como explorá-la? A idéia de povoar não ocorre de início. É o comércio que os interessa, sua expansão, o favorecimento para a balança comercial do reino luso. Assim tratam no início do conhecimento territorial com relativo desprezo. Mas mesmo assim se interrogam, que tipo de gênero se adapta aquele território, que tipo de madeira possuem, existem minérios, o clima e solo são propícios para a agricultura, os nativos podem ser utilizados, de que forma? Há um ajustamento entre os tradicionais objetivos mercantis e os que são conservados para as novas condições em que se realizará a empresa lusitana. No seu conjunto, e vista no plano mundial e internacional, a colonização dos trópicos toma o aspecto de uma vasta empresa comercial, mais complexa que a antiga feitoria, mas sempre com o mesmo caráter que ela, destinada a explorar os recursos naturais de um território virgem em proveito do comércio europeu. É este o verdadeiro sentido da colonização tropical, e ele explicará os elementos fundamentais, tanto no econômico como no social, da formação e evolução históricas dos trópicos americanos. ${ }^{16}$

E com esse olhar que o conquistador europeu substituirá o escambo pela agricultura alterando completamente o convívio com o indígena. Os nativos passam a ser encarados como um obstáculo à posse da terra e uma fonte desejável e insubstituível de trabalho. Surge então os conflitos e as tensões sociais com os indígenas. O objetivo dos conquistadores só poderiam ser alcançado pela expropriação territorial, pela escravidão e pela destribalização [desarticulação da estrutura tribal, liderada pelos pajés através do xamanismo e pelos caciques ou principais da aldeia de forma a subjugá-los]. ${ }^{17}$

16 Caio Prado Junior, Formação do Brasil Contemporâneo, p.25.

17Segundo Fernando A. Novais, o modo de produção escravista-mercantil seria uma forma-limite do modo de produção colonial e este, por sua vez, teria o estatuto teórico de peça do sistema colonial. Uma vez que os mecanismos do "sistema colonial mercantilista" constituem o determinante estrutural do conjunto, seu elemento básico e definidor, resulta que somente o próprio sistema colonial se apresenta com identidade substantiva. Estrutura e Dinâmica do Antigo Sistema Colonial. São Paulo,Cadernos CEBRAP,1974,n.17,p.1213,27,31-34. Gorender diante desta análise reflete que as relações de produção da economia colonial precisam ser estudadas de dentro para fora, ao contrário do que tem sido feito, de fora para dentro, tanto a partir da família patriarcal ou do regime jurídico da terra, quanto a partir do mercado ou do sistema colonial. O escravismo colonial, p.6-7.

Manuela Carneiro da Cunha argumenta que de meados do século XVII a meados do século XVIII, quando Portugal estava interessado em ocupar a Amazônia, os jesuítas talharam para si um enorme território missionário [facilitando a destribalização e a escravidão em favor da conquista do Império Português]. Foi o seu século de ouro, junto a influência a D.João IV e ao Papa, que Pe.Vieira logrou obter. Após a expulsão dos jesuítas por Pombal, 
Em contato com os nativos, os portugueses de São Vicente, perceberam as rivalidades tribais entre Tupiniquim [aliados dos portugueses] e Tupinambás [aliados dos franceses] aproveitando desta situação, suas alianças tinham o objetivo de trazer trabalhadores [cativos de guerra] para abastecer suas lavouras, extrair recursos naturais como o paubrasil, [sempre na finalidade de comércio] e formar "fronteiras vivas" para proteger contra ataques de corsários e concorrentes comerciais do Império Português[franceses, holandeses e espanhóis].Mas os cativos não se transformavam em escravos tão facilmente e também não conseguiam vendê-los, todo este processo envolvia a questão do ritual do sacrifício humano. Com o passar do tempo adquirindo confiança dos líderes das aldeias tupiniquins, como Tibiriçá e o apoio de João Ramalho, genro deste cacique, as alianças fortaleceram-se; já o indígena aproveitou esta aliança para mostrar superioridade aos seus adversários sem se preocupar com as consequiências agravadas pelos surtos de doenças contagiosas, dizimando tribos inteiras.

O indígena não aceitou pacificamente esta transformação de aliado para escravo, manipulado pelas guerras. A partir da instituição das donatárias, o sistema tribal teve que ser alterado internamente de modo que várias tribos se submetessem às comunidades européias, assim desestruturando seu antigo sistema, provocando várias revoltas. Em estudos realizados por Florestan Fernandes, a reação indígena teoricamente aconteceu em três situações :

1. de preservação da autonomia tribal por meios violentos, a qual teria de tender, nas novas condições, para a expulsão do lavrador branco;

2. a submissão, das duas condições indicadas, de "aliados" e de "escravos";

em 1759 e com a chegada de D.João VI ao Brasil, em 1808, a política indigenista viu sua arena reduzida e sua natureza modificada: não havia mais vozes dissonantes quando se tratava de escravizar o indígena e de ocupar suas terras. A partir do século XIX, a cobiça se desloca do trabalho para as terras indígenas [grifo nosso]. Um século mais tarde, deslocarse-á novamente: do solo, para o subsolo indígena [grifo nosso]. Política Indigenista. In: Manuela Carneiro da Cunha, op.cit., p.16

[Toda essa política nos faz refletir na situação atual dos povos indígenas no Brasil, que passaram de milhões de habitantes no início da exploração das terras da América Portuguesa para hoje existirem aproximadamente 300.000 mil habitantes [considerando as pessoas que vivem nas terras indígenas], confinados em parques sob a administração da FUNAI, órgão federal responsável em cuidar dos indígenas no Brasil. Fonte:Anuário estatístico do Brasil,1998.Rio de Janeiro: IBGE, v.58,p.1-143-1152,1999/www,ibge.gov.br/Brasil:500 ]. 
3. de preservação da autonomia tribal por meios passivos, a qual teria de assumir a feição de migrações para as áreas em que o branco conquistador não pudesse exercer dominação efetiva ${ }^{18}$

A primeira forma de reação pode ser exemplificada pela Guerra dos Tamoios (1540-1560, tomando todo o litoral e muitas partes de serra acima), bem conhecida pelos relatos de Nóbrega e Anchieta, cujo objetivo era demonstrar discordância quanto às atitudes dos colonos vicentinos e jesuítas, porém o sucesso desta luta foi parcial, as alianças facilitaram a desfragmentação tribal, colocando índio contra índio, beneficiando o conquistador europeu. A segunda reação foi posta em prática pelos Tupis em toda a região do Brasil Colonial, ora pela influência dos jesuítas nos aldeamentos via "resgate", ora em "guerra justa". Em muitos casos o suicídio seria a alternativa, mas as doenças contraídas nos contatos com o branco, a escassez de víveres, trabalhos forçados de toda espécie, faziam com que o regime imposto dizimasse nações diversas. A terceira forma de reação teve pouca eficiência, devido às "entradas" e "bandeiras", como atestam os relatos de Knivet, Frei Vicente do Salvador, Gabriel Soares, jesuítas, etc. A migração de várias nações indígenas para o sertão, em especial a região do Vale do Paraíba, tinha o isolamento como defesa da autonomia tribal, mas os sertanistas paulistas conseguem dizimá-los, aldeálos ou escravizá-los fornecendo mão-de-obra para os conventos, fazendas paulistas e armações para a região mineradora, aproveitando esta situação para apresar mais indígenas. ${ }^{19}$

18 Florestan Fernandes. Antecedentes indígenas: organização social das tribos tupis. Reação dos índios. In : Sérgio Buarque de Hollanda. História Geral da Civilização Brasileira, tomo I, p.84-85.

19 Na região do Vale do Paraíba, nos finais do século XVI, através de cartas do Pe. Anchieta temos a migração dos índios guaianazes, fugitivos da vila de São Paulo, devido as guerras de irmãos contra irmãos e escravização impiedosa dos gentios ( Carta de 16 de abril de 1563 do Pe.Anchieta para Padre-Mestre Diogo Saynez, Preposto Geral, traduzida do espanhol pelo Cônego J. da C. Barbosa, publicada no n.8 da RIHG em 1841) buscam o sertão como abrigo e se alojam à margem esquerda do Rio Paraíba, entre a Serra do Mar e da Serra da Mantiqueira, a $10 \mathrm{Km}$ da atual cidade de São José dos Campos, dando origem a Aldeia do Rio Comprido, mais tarde Aldeia de São José do Paraíba, futura cidade de São José dos Campos. Este grupo será aldeado pelos jesuítas que obtiveram em 1643 sesmaria para os indígenas, composta de quatro léguas em quadra, conforme o livro 11 das Sesmarias Antigas, concedidas por João Mafra, fidalgo da Casa de Sua Majestade, Ata lavrada pelo escrivão Antônio Velho de Mello. (Ver Ernani Silva Bruno, Viagem ao País dos Paulistas,1966). Foi para os tropeiros um posto de remonta e pouso ligando Sorocaba São Paulo - Vale do Paraíba - Rio de Janeiro.

As migrações dos indíos guaianazes continuaram nos finais do século XVI, originando o povoado de São Francisco das Chagas de Taubaté, índios que foram inimigos dos Piratininganos no tempo em que a Vila de Santo André foi arrasada a mando dos paulistas, tendo como pioneiro deste sertão o Capitão Jacques Félix, que levara de São Paulo sua família e grande número de bugres administrados, além de cavalos e bois, levantando a sua custa igreja e cadeia, montou ali o primeiro engenho para açúcar e aguardente do Vale do 
E qual política indigenista existia? Como resolver os conflitos nos aldeamentos e as fugas? Tanto nas colônias da América Espanhola como na colônia da América Portuguesa é notável o descaso pelas leis metropolitanas, uma legislação que não atendia às condições do meio. Contraditória, oscilante, hipócrita são os adjetivos empregados pela historiografia tradicional para qualificar a legislação e a política da Coroa portuguesa em relação aos povos indígenas do Brasil Colonial. Leis que não trouxeram nenhuma eficácia em defesa dos índios perante a ganância do conquistador europeu. Na verdade, o que havia era uma distinção no tratamento dos índios considerados aliados [os aldeados e subordinados pela conversão] e dos índios hostis e dispersos pelo sertão. Aos primeiros a liberdade fora sempre garantida juridicamente, já os índios inimigos, capturados em guerra justa, podiam ser escravizados pelos moradores. E o que era para ser uma exceção, segundo a legislação, transformou-se na ação indiscriminada de expedições apresadoras e guerras violentas contra os naturais da terra, que foram realizadas principalmente pelos moradores de São Paulo. ${ }^{20}$

Paraíba, [dizimando e escravizando todo o gentio que encontrasse. Mais adiante falaremos desta "entrada"]. In: Agê Junior. São José dos Campos e sua história. São Paulo, editora Oficinas da Offset Cópia Ltda.Indústria Gráfica.s/d.

[Há pouquíssimas fontes secundárias sobre a origem das vilas do Vale do Paraíba, existem muitos documentos para serem estudados, falta interesse por parte dos historiadores em desenvolver as lacunas deste período, espero que os futuros pesquisadores olhem com carinho para os estudos desta região que está por ser analisada].

Outro aldeamento que existiu na região do Vale do Paraíba, foi dos Puris de São João Batista de Queluz, criado pelo Governador da Capitania de São Paulo o General Antonio Manuel de Mello Castro e Mendonça, em 1800, em terras de Antonio José de Carvalho, destinado a reunir os últimos Puris do sertão.dando origem a futura cidade de Queluz. Para administrar o aldeamento foi nomeado Diretor Januário Nunes da Silva e para a parte religiosa como Pároco o Padre Francisco das Chagas Lima. In: Paulo Pereira dos Reis. Os Puri de Guapacaré e algumas achegas à História de Queluz. Revista de História n.61, São Paulo,1965, p.130-139. Ver também, pesquisas de José Luz Pasin. Algumas notas para a História do Vale do Paraíba: desbravamento e povoamento. São Paulo.Conselho Estadual de Cultura.Secretaria da Cultura,Ciência e Tecnologia,1977.

20 A legislação indigenista portuguesa não foi objeto de grande interesse para a historiografia brasileira. Existem trabalhos que discutem as disposições jurídicas em relação aos índios durante o período colonial, mas, de um modo geral, essas análises não foram muito além da descrição das leis. Embora o debate jurídico e teológico fora menos intenso em Portugal do que na Espanha, a questão esteve refletida na sua política colonial, como comprovam a quantidade de documentos que tratam de tais questões: leis,alvarás,cartas,provisões,decretos, regimentos, uma extensa documentação oficial produzida ao longo dos séculos XVI ao XVIII. A política indigenista deve ser entendida como parte do sistema de dominação colonial.[grifo nosso] Ludmila Gomide Freitas, Dissertação de Mestrado A Câmara Municipal da vila de São Paulo e a escravidão indígena no século XVII(1628-1696), UNICAMP,2006.p. 33.

Beatriz Perrone-Moisés refletindo sobre esta questão observa que a falta da compilação e da publicação integrais dessa extensa quantidade documental, dificulta o trabalho historiográfico mas não é motivo principal do reduzido numero de estudos mais aprofundados, a lacuna provém da idéia de que Portugal teria dado pouco interesse à 
Ora favorecia os jesuítas que vindicavam a liberdade aos índios, ora a pressão dos colonos que reclamavam escravos para o desbravamento da terra, a Coroa não sabia decidir-se. O concelho da vila, oficial representante do Estado português tinha a função de executar a política metropolitana e mediar os interesses locais conflitantes, em nome do bem comum e do desenvolvimento da empresa colonial. Mas na medida do possível os oficiais do concelho tinham a intenção de ocultar seus procedimentos discordantes com a lei. A documentação não deixa clara as nuances de sua atuação em apoio às ambições escravistas dos colonos. Caso contrário, estariam eles próprios a admitir o descumprimento da legislação indigenista. ${ }^{21}$ Daí as incertezas e instabilidade que provocaram fórmulas cautelosas nos testamentos e inventários, onde os senhores descarregavam suas consciências sobre a liberdade dos índios nas Justiças de Sua Majestade, havendo por bem feito o que elas neste particular determinassem, pelas leis desta república.

Desde os primórdios do século XVII, ao lado dos negros do gentio da terra, nomeados e avaliados como escravos, começa aparecer nos inventários paulistanos os serviços forros. Com o passar do tempo estes serviços começam a aumentar, diminuindo os escravos, a não ser os negros da guiné. Somem os termos utilizados como cativos do gentio brasílico e aparece gente forra, serviços obrigatórios, peças forras serviçais, todo um rebanho humano que encontramos no rol de peças dos testamentos e inventários paulistas. ${ }^{22}$ Depois os indígenas passam a chamar-se administrados do inventariado ou servos de sua administração. Muda-se os rótulos, não medem as conseqüências. Mais tarde as Cartas Régias de 26 de janeiro e 19 de fevereiro de 1696, vieram legalizar esse fato, concedendo aos colonos de São Paulo e seus descendentes a administração dos índios. A escravidão passa à tutela, favorecendo os abusos e a exploração sem limites dos índios administrados. Em geral, a justiça e as partes não se atrevem a ferir de frente a lei e empregam uma estratégia para burlá-la ou sofismá-la. Não mandam avaliar os índios, o que se avalia é a atividade que representam, o serviço que são capazes de prestar, o rendimento que produzem. O alvidramento ou serviços alvidrados se converte em regra. No

questão jurídica colonial, privilegiando o aspecto político-econômico da questão em detrimento de seu aspecto propriamente jurídico.Índios livres e índios escravos. In: Manuela Carneiro da Cunha,op.cit. p.115

21 Ludmila Freitas,op.cit.,p.7-8

22 Conforme já comentamos sobre o trabalho de Ernani Silva Bruno. O que revelam os inventários sobre escravos e gente de serviço no início deste capitulo.Ver também Alcântara Machado,op.cit.,p.160 
caso da vila de Taubaté, os serviços alvidrados eram em alguns casos por grupo ou avaliava-se a ferramenta junto com o escravo, se houvesse um filho bastardo mameluco também era avaliado, onde o filho seguia a condição social da mãe.

\section{Peças alvidradas do gentio da terra por grupo :}

Foi alvidrado Sebastião com sua mulher Luzia e uma cria por nome Felipe com sua alvidração $40 \$ 000$ [quarenta mil réis] ${ }^{23}$

Foi alvidrado os serviços de Sebastião e sua molher Generoza ambos em $70 \$ 000\left[\right.$ setenta mil réis] ${ }^{24}$

Foi alvidrado pelos alvidradores o serviço de Agostinho do gentio Toabaiara [Tabajara] e sua mulher Asença Goarulha em sua alvidração 35\$000 [trinta e cinco mil réis]

Timoteo e sua mulher Felisiana do gentio Tobaiara em sua alvidração $38 \$ 000$ [trinta e oito mil réis]

Romão Tobaiara e sua mulher Maria em sua alvidração 38\$000[trinta e oito mil réis]

Ynosensio e sua mulher Rufina com uma cria de peito por nome Bastiana em sua alvidração $28 \$ 000$

Clemente e sua mulher Ypolita com uma cria de peito por nome Joana em sua alvidração $28 \$ 000$

Salvador e sua mulher Maria com uma cria de peito por nome Antonio em sua alvidração $28 \$ 000$

Baltezar e sua mulher Luzia com uma cria de peito por nome Brizida em sua alvidração $28 \$ 000$

Gregório e sua mulher Ylaria em sua alvidração $28 \$ 000^{25}$

Mariana e seu marido Francisco, Marselino e seu filho Salvador, Brás velho e sua mulher Sara na idade de um e outro de oitenta anos pouco mais ou menos e doente os quais foram alvidrados o seu serviço de um e outro pelos avaliadores em seis patacas ambos [uma pataca valia $\$ 320$, trezentos e vinte réis] no total de $1 \$ 920$ [um mil novecentos e vinte réis] ${ }^{26}$

Foram alvidrados os serviços de Fernando, com sua mulher e sua filha Tereza;Agostinha;Silveria; Abrozio, todos em sua alvidração de $70 \$ 000^{27}$

23 Inventário Antonio da Costa Gil,caixa 3, doc.7, 1692.

24 Testamento/Inventário Francisco Coelho de Abreu, caixa 3, doc.20, 1697

25 Inventário Bertholomeu da Cunha Gago, caixa 2, doc. 2, 1685

26 Inventário de Maria de Oliveira, caixa 2, doc.44, 1688.

27 Inventário de Manoel Nunes Pereira, caixa 3,doc.15,1696 Ver também inventário de Ignes Gonçalves Gil, caixa 3 , doc.29, 1698; 


\section{Peças do gentio da terra alvidradas junto com a ferramenta utilizada:}

Foi avaliado uma tenda de ferreiro e o negro ferreiro do gentio da terra por nome Ignosencio em sua avaliação $32 \$ 000$ [trinta e dois mil réis]

Foi avaliado uma tenda de seleiro com o negro seleiro do gentio da terra por nome Dimas em sua avaliação de $32 \$ 000$ [trinta e dois mil réis]

Foi avaliado um tear de panno com o teselao negro do gentio da terra por nome Luis com sua avaliação 28\$000[vinte e oito mil réis]

Foi avaliado outro tear de panno com o teselao negro do gentio da terra por nome Visente em sua avaliação $28 \$ 000$ [vinte e oito mil réis] ${ }^{28}$

\section{Peças alvidradas de filhos bastardos seguindo a condição social da mãe gentio da terra:}

Um filho por nome Paulo mamaluco em sua alvidração 25\$000[vinte e cinco mil réis] $]^{29}$

Catherina mulata escrava e seu filho Salomão alvidrados em 80\$000[oitenta mil réis] $]^{30}$

Tereza mulatinha filha do gentio da terra alvidrada em 20\$000[ vinte mil réis $]^{31}$

Havia no começo, bem como nos finais dos seiscentos diferença entre o serviço obrigatório e o cativeiro. Eram inalienáveis as peças serviçais e a justiça não permitia que fossem avaliadas, seqüestradas, vendidas ou arrematadas em praça pública. Porém, a inalienabilidade restringe, mas não exclui, o direito que tem o senhor de tratar o negro da terra como coisa sua, eram animais de trabalho e assim eram tratados, quando no rol de peças os casais possuem "crias" é comum nos testamentos e inventários paulistas , encontrarmos escravos indígenas arrolados entre os bens e leiloados para o pagamento de dívidas, são doados para dotes e partilhados entre os herdeiros, sem que haja qualquer manifestação jurídica. O mesmo ocorreu na vila de Taubaté neste mesmo período:

Um negro como dote. : ${ }^{32}$

\section{Parte do testamento}

(...) Declaro que tenho em casa de Sebastião Barros dois negros quiricaios que me vendeu a conta do que me deve e me resta a dever o que na verdade se achar.

28 Inventário de Martha de Miranda, caixa 2, doc. 45, 1689

29 Testamento e inventario de Diogo Teixeira da Cunha, caixa 3, doc.33 ano 1699

30 Inventario de Manoel Nunes Pereira, caixa 3, doc.15, 1696

31 Testamento e inventário de Ignes Gonçalves Gil, caixa 3, doc.29,1698

32 Inventário de Alberto Lobo Louzada,caixa 2, doc.4,1680 


\section{Parte do inventário}

\section{Termo de avaliação e alvidração das pessas do gentio da terra}

(...) Um casal, um negro e uma negra com sua cria de dois anos mais ou menos e um rapaz em sua alvidração $25 \$ 000$ [vinte e cinco mil réis] (...) Declaro ser o casal acima a cria de dois annos e o rapaz que estão alvidrados acima, achou-se em dinheiro $10 \$ 140$ [dez mil cento e quarenta réis]. Os quais $10 \$ 140$ tirou o juiz para às custas deste inventário, que importarão as ditas custas do juiz, escrivão, avaliado em $15 \$ 720$ [quinze mil setecentos e vinte réis] e pera esta conta dos ditos $15 \$ 720$ se tirou $5 \$ 580$ [cinco mil quinhentos e oitenta réis] de um cazal de pessas que se vendeu por $25 \$ 000$ [vinte e cinco mil reis] de que tudo fiz este termo.$^{33}$

As obrigações do senhor nos testamentos para com seu administrado são de orientar seus herdeiros que tratem as peças com termos de Deus e brandura, fazendo-lhes freqüentar com cuidado os sacramentos da igreja e assistir ao sacrifício da missa e toda a caridade, olhando por elas e benfeitoriando-as, assim no espiritual como no temporal, ensinando à doutrina e caminho de Deus e a todos os bons costumes, mandam os testadores que se pague seu espêndio, conforme a lei de El-Rei. Mas o pagamento era feito segundo se costuma na terra, dando-lhes a plantar uma roça para seu comer; acudindo-os com o vestuário e sustento; cobrindo-os em paga de seu trabalho; dando-lhes cada ano um fato de vestir. ${ }^{34}$

É evidente que embora a transformação de escravo para índio administrado não levou os nativos aceitarem pacificamente a forma de como eram tratados, as fugas eram constantes. Diversos motivos podiam estimular a fuga de um escravo. Maus tratos, o labor sobre-humano nas minas e engenhos, o desejo de se reunir a parentes que viviam numa outra fazenda ou mesmo o anseio de ser livre, toda a situação convergia para o abandono do senhor. Como na vila de São Paulo, ocorreu na vila de São Francisco das Chagas de Taubaté a mesma reação com relação às fugas, como segue :

\section{Pessoas fogidas}

Baupp.[Batista] e Matheus soltos

Visente e Alberto soltos

Bertholameu casado e Gregório solto ${ }^{35}$

Hum negro por nome Damião que anda fugido. ${ }^{36}$

33 Testamento e inventário de Bernardo Bonfillio, caixa 2,doc.8, 1681.

34 Alcântara Machado, op.cit., p.161. Devo também duas varas de pano de algodão a uma negra de casa por nome Fillipa. Testamento de Francisca Cardoza, caixa 1, doc.5,1655,Taubaté.

35 Inventario Martha de Miranda, caixa 2,doc.45,1689

36 Inventario de Bertholomeu da Cunha Gago, caixa 2,doc.02,1685. 
Huma negra que anda fugida por nome Ribana; hum negro da nassão pory que fogio pêra casa de João Velloso, um rapaz por nome Tobias, uma rapariga de cinco ou Seis anos pouco mais ou menos. ${ }^{37}$

(...) declarou o dito viúvo o Coronel Sebastião de Freitas que Antam e Romana soa Fogidos que paressendo se faça partilhas deles e declarou mais que podem parecer Que há annos são fogidos. ${ }^{38}$

Assim como em outros sistemas escravistas, acontecia entre os colonos da vila de São Paulo, dos bairros e futuras vilas paulistas o mesmo tratamento de coação e violência para com seus subordinados, impondo disciplina autoritária sem escrúpulos. "Ao escravo, pão, correção e trabalho". ${ }^{39} \mathrm{O}$ que não difere do ensinamento do grande pensador grego : "Três coisas são a considerar no escravo: o trabalho, o castigo e o alimento"40, correção e castigo no sentido de disciplina. As Ordenações Filipinas autorizavam o castigo dos escravos e de outras pessoas dependentes, mas puniam os excessos como o do ferimento com arma. ${ }^{41} \mathrm{~A}$ Coroa portuguesa várias vezes se preocupou, em cartas régias e provisões, com a observância da moderação nos castigos aplicados aos escravos no Brasil. ${ }^{42}$ Preocupação que a Coroa espanhola também teve. A moderação do castigo podia ser efetiva ou não, menos do temperamento do senhor do que das exigências objetivas da economia escravista. Não devemos supor que o senhor tinha interesse em inutilizar seus escravos, afinal era seu dinheiro, o objetivo dos castigos eram para correção e exemplos para os demais escravos de sua fazenda.

Um fato incomum de subjugação, aconteceu na vila de São Paulo em fevereiro de 1624, com o assassinato do Principal Timacauna por pombeiros negros dos brancos [índios do povoado especializados no apresamento de índios do sertão], quando este se dirigia àquela vila com toda sua gente para se converter à religião católica. Após sua morte escravizaram e repartiram sua gente entre seus amos e senhores. ${ }^{43}$

37 Testamento e inventario de Francisco Pedrozo, caixa 2, doc.41,1687.

38 Testamento e inventário de Maria Fragosa, caixa 2,doc.38,1687

39 Conforme o livro bíblico Eclesiástico, 33,25, o que nos interessa aqui é mostrar a visão dos hebreus com relação aos seus escravos.

40 Aristóteles,Livro Primeiro,1344ª 35, p.25. In: Jacob Gorender, O escravo e o trabalho O escravismo colonial, p.55-56

41 Ordenações Filipinas.Livro Quinto,Tit.36,Parágrafo $1^{\circ}$.

42 Cartas Régias de 20 de março de 1688, de 23 de fevereiro de 1689 e de $1^{\circ}$ março de 1700.Textos. In:Goulart, José Alípio. Da Palmatória ao Patíbulo.p.186-187

43 Ver Devassa que o superintendente nas matérias de guerra da Costa Sul e da Vila de São Paulo da Capitania de São Vicente e Administração Geral das Minas, Martim de Sá, mandou fazer sobre a morte do índio principal Timacauna por pombeiros dos brancos.In: Arquivo Histórico Ultramarino, a partir dos catálogos do Projeto Resgate "Barão do Rio 
Os jesuítas, por várias vezes, denunciaram as formas inadequadas de tratamento utilizadas pelos colonos paulistas, [com relação aos indígenas] alegando que sua administração nos aldeamentos era a mais correta, tratando os negros da terra como vassalos do rei. O convívio com a cultura do "colonizador" europeu deveria ocorrer através de sua conversão pacífica ao cristianismo, por meio dos enviados religiosos. Neste projeto, atribuía-se ao rei, não o usufruto do direito de conquista, mas o cumprimento de uma missão sagrada, em que ele aparecia como Imperador que reinava sobre numerosos reis e indígenas, respeitando-lhes a autoridade segundo os preceitos do direito natural. ${ }^{44}$

Outra prática que mostra com nitidez o caráter escravista do regime da administração dos índios, está fortemente ligado à alforria. De forma a livrar-se das obrigações do serviço particular e de suas responsabilidades, era através de uma carta de liberdade devidamente registrada em cartório ou mediante uma parte específica no testamento do senhor. A condição incerta dos cativos apresentava um problema ao mesmo tempo teórico e prático na jurisprudência colonial, sobretudo a partir do momento em que alguns índios passaram a reivindicar a própria liberdade, apoiando-se na legislação colonial. ${ }^{45}$

\section{Exemplos de alforrias em testamentos e inventários da vila de Taubaté:}

Parte do testamento Maria Delgada

Declaro que tenho ua menina de hua negra minha por nome Inês e a menina por nome Domingas, filha de Simão Bauptista meu neto acoal deixo por livre e forra e dezobrigada por minha morte. ${ }^{46}$ [grifo nosso]

Partes do testamento Manoel Borges Conseiro

Declaro que sou filho legítimo de Francisco Borges e Elena Rodrigues moradores que foram na Villa de São Paulo. Declaro que nunca fui casado e declaro mais que tenho três filhos e uma filha naturais: Manoel, Antonio, Francisco e Maria todos filhos meus e de hua negra minha do gentio da terra por nome Adriana aqual deixo forra e liberta por bons serviços que della tive e os ditos filhos declarados são meus legítimos herdeiros. ${ }^{47}$

Branco" no que se refere à Capitania de São Paulo. AHU_ACL_CU_023-01, Cx.1, D.3, 9 de fevereiro de 1624.

44 Carlos Henrique Davidoff. Bandeirismo: verso e reverso,p.32-33.

45 Interessante análise de John Monteiro, onde discute bem este tema em Caminhos da Liberdade: alforrias. In: Negros da terra,p.210-220.

46 Inês era índia e Simão era branco, pais de Domingas mameluca, cuja avó à liberta.Testamento e inventário de Maria Delgada, caixa 1,doc.7,1657.

47 Testamento e inventário de Manoel Borges Conseiro, caixa 2,doc.5,1680. Em seu inventário seus filhos são declarados herdeiros de suas propriedades, livres como sua mãe, de acordo com o testamento lavrado em cartório.O juiz assim determina, conforme vontade do inventariado. 


\section{Partes do inventário João do Prado Martins}

Titolo dos filhos que ficaram por morte do dito defunto (...) Mais hua filha natural feita sendo o dito defunto solteiro por nome Visemcia Martins (...) Titolo e termo de partilhas das pessas (...)

Termo de juramento que deve o dito juiz ao Capitão Bras Esteves Lemme para aver.... Curador da órfã filha natural que ficou do defunto por nome Visemcia Martins. E logo aos 5 dia s domes de Julho do mesmo atrás declarado deu o dito juiz ordinário e dos órfãos pella ordenasam...(...) (...) juramento dos santos evangelhos sobre hum livro delles ao capitam Bras Esteves Lemme para que servisse de curador e tutor da órfã filha natural que ficou do dito defunto Joam do Prado Martins, para que como seu tutor...pellos bens da dita órfã Vicência Martins da maneira que sua Majestade, encomenda em sua ordenação aos curadores e tutores de órfãos, a qual órfã lhe couberão por partilhas que the couberam como legitimamente lhe cabia tanto como aos demais por constar, digo aver o dito defunto a dita sua filha Vicência Martins em solteiro e antes de matrimônio consumado lhe couberam dar pessas forras [grifo nosso] quatro a saber a mãe da dita órfã por nome Elena e seu marido Thomas [ grifo nosso, a própria mãe e padastro foram entregues como escravos para a órfã Vicência, no sentido de cuidar da menina] e hua negra por nome Illaria e outra por nome Phelipa as coais pessas logo foram entregues ao Capitam Bras Esteves Lemme como curadorda dita órfã e o dito Capitam Bras Esteves Lemme aseitou a dita curadoria e se deu por entregue das ditas quatro pessas e assinou aqui com o dito juiz e escrivão que o escrevy. Bras Esteves Leme, Bernardo Sanches Pimenta. ${ }^{48}$

\section{Exemplo de Cartas de Alforria que foram solicitadas pelos próprios indígenas administrados, da vila de Taubaté:}

CARTA DE ALFORRIA feita a requerimento de Marcela, negra do gentio da terra, serviço de Francisco Rodrigues Moreira. Em 22 de novembro de 1698, na vila de São Francisco das Chagas De Taubaté. (...) Diz Marcela serva de Francisco Rodrigues Moreira que por sua sorte teve do dito seu amo uma filha como é fama pública e constante e, como por Lei da Ordenação, no Livro Quinto dela, que toda a escrava que tiver cópula com seu senhor fique forra e ela suplicante o deve ser ainda com maiores titulos por preferir ao gentio de guiné, por ser índia e crioula, não procurando a alforria para algum dano mas antes o que lhe pode causar o mau trato que pode ter e risco de sua vida e atendendo V.Mercê como Justiça amparar e favorecer a liberdade para oque pede a V.Mercê mande tomar depoimento ao dito seu amo com juramento para que conferindo com o referido em sua petição e por descargo de sua consciência mandará. (...)Certifico eu José Marques de Andrada, Escrivão da Ouvidoria desta dita Capitania que por virtude do despacho acima do Ouvidor o Capitão Domingos Luis Cabral dei vista a Antonio Rodrigues Moreira do conteúdo na petição acima escrita em favor da dita requerente Marcela, do gentio da terra, serviço de Francisco Rodrigues Moreira e me deu por resposta não fugia do que era de direito e desencargo de sua consciência que concedia a liberdade da dita negra Marcela mas que havia acompanhar sua filha e não andar de casa em casa e só assistiria em cada de quem se tivesse confiança poder criar a dita cria com

48 Inventário de João do Prado Martins, caixa 01,doc.04,1653. O pai reconhece e liberta a filha, amparando-a conforme o próprio documento relata. 
todo ensino que se deve dar a toda pessoa cristã. (...)O que visto eu a resposta do dito Francisco Rodrigues Moreira e atendendo o grande dano que poderia resultar e atendendo e respeitando o direito que El Rei meu senhor ordena em suas Ordenações sobre este caso conforme o capítulo do Livro Quinto o dispõe e ser de cabelo corredio hei por bem mandar lhe passar a presente minha Carta de Alforria a qual faço saber a todos os senhores Corregedores, Ouvidores,Juízes,Justiças e mais Oficiais de Justiça e pessoas de qualquer qualidade, grau, condição por tal a conheçam a dita negra Marcela por livre, forra e isenta de toda servidão e cativeiro somente será obrigada a criar sua filha e acompanhá-la dando-lhe ela o trato conforme sua mãe que é; e se em algum tempo sua filha a não respeite como mãe sua que é poderá ir por onde lhe parecer e assistir na casa que melhor trato se lhe der e não será obrigada a sujeito algum conforme o direito e Lei o dispõe de que se dará cumprimento inteiro a esta minha Carta de Alforria $e$ Liberdade e por tal a conheçam e hajam por tal a dita negra Marcela de que mandei passar a presente minha Carta em que se assinou o dito Francisco Moreira e eu de meu sinal e selo que perante mim serve em vinte e dois dias do mês de novembro da dita era declarada eu Tabelião e Escrivão dos Órfãos e Ouvidoria a escrevi e lancem em este Livro de Notas para dela dar os traslados que pedidos me forem eu dito digo em o mesmo dia, mês e era declarada nesta vila de Taubaté eu dito Tabelião e Escrivão dos Órfãos e Ouvidoria o escrevi. Cabral/Francisco Rodrigues Moreira/Domingos Luis Cabral. $^{49}$

CARTA, digo DECLARAÇÃO que faz Manoel Fernandes Urtunho e sua mulher Domingas Do Prado. Em 01 de dezembro de 1698, na vila de São Francisco das Chagas de Taubaté. Seu negro Domingos Dultra paga uma dívida do casal e em troca compra a liberdade de sua filha Sebastiana.Saibam quantos este público instrumento de Carta de Alforria virem que no ano do nascimento de Nosso Senhor Jesus Cristo de mil e seiscentos e noventa e oito anos, nesta vila de São Francisco das Chagas de Taubaté, Capitania de Nossa Senhora da Conçeição de Itanhaém, de que é governador e donatário perpétuo dela por Sua Majestade, que Deus guarde, o Conde da Ilha do Príncipe, partes do Brasil, (...). Ao primeiro dia do mês de Dezembro da dita era nesta dita Vila em pousadas de mim Tabelião adiante nomeado apareceu Manoel Fernandes Urtunho e bem assim sua mulher Domingas do Prado e por eles ambos, marido e mulher, me foi dito perante as testemunhas adiante nomeadas e assinadas que eles haviam feito contrato com sua mãe Maria da Cunha sobre um casal de peças como largamente consta da Escritura de Venda que a dita sua mãe lhe havia passado e como eles na ocasião não tem dinheiro pagou seu mulato Domingos Dultra a sua mãe e a seu irmão Amaro da Cunha trinta e dois mil réis a conta do que ele dito devia pagar por sua mãe para o que concederam, tanto marido e mulher, visto seu negro dar o seu dinheiro por sua agência havia granjeado [com trabalho ou esforço própriol e deram em pagamento a sua filha Sebastiana e a haviam por forra sem obrigação alguma e por assim outorgarem e ser verdade me apresentaram uma quitação de Recibo de Venda da dita quantia da dita rapariga e só fica devendo o dito Manoel Fernandes a sua mãe o que por direito for a qual letra e sinal eu tabelião conheço ser de Manoel da Costa Camargo e sina de Amaro da Cunha com que me mandaram passar

49 Carta de Alforria feita e requerida por Marcela, negra do gentio da terra, serviço de Francisco Rodrigues Moreira, em 22 de novembro de 1698. Livro de Registros e Escrituras, período 1692-1700, bloco V (1698-1700). 
esta Carta de Alforria nestas Notas e que em nenhum tempo seus herdeiros não poderão entender com a dita rapariga e mandaram passar a presente e dar os traslados que pedidos me forem estando por testemunhas Inofre de Chaves, Gaspar Soares, Pedro Dias Fernandes pessoas de mim Tabelião conhecidas e moradores nesta dita Vila que assinaram com os ditos outorgantes. E pela dita outorgante não saber assinar rogou a mim tabelião por ela assinasse o que fiz a seu rogo, eu José Marques de Andrada tabelião público do Judicial e Notas que o escrevi.Assino a rogo da dita outorgante Domingas do Prado - José Marques de Andrada. Cruz de Manoel Fernandes Urtunha, Pedro Dias Fernandes, Gaspar Soares Calheros. ${ }^{50}$

A partir do conjunto de ações litigiosas movidas por " descendentes de carijós", delineava-se o processo de desagregação da escravidão indígena com importantes implicações para a questão da identidade étnica da população local. De fato, a maior parte dos litigantes que alcançava sentenças favoráveis passava a integrar a camada mais numerosa da sociedade paulista, composta de lavradores pobres e agregados livres, os precursores da "sociedade caipira" tão fartamente estudada no presente século. Apenas uma minoria de índios alforriados "reintegrava-se" aos aldeamentos da região, seguindo uma estipulação da política indigenista do início do século XVIII. Assim, nesse processo, a tendência principal era o afastamento do passado e da identidade indígena. ${ }^{51}$

\subsection{Jesuítas: uma visão oposta dos colonos vicentinos}

A organização da Igreja no Brasil entre 1550-1800 era grande parte controlada pelo Padroado, uma prerrogativa da Coroa Portuguesa baseada no fato de o rei ser grão-mestre de três tradicionais ordens militares e religiosas de Portugal : a de Cristo (a mais importante), a de São Tiago da Espada e a de São Bento, a partir de 1551. A Ordem de Cristo era herdeira da dos Templários e gozava de grande influência. $\mathrm{O}$ direito de padroado foi cedido pelo papa ao rei português com a incumbência de promover a organização da Igreja nas terras "descobertas", de sorte que foi por intermédio deste Padroado que a expansão do catolicismo no Brasil foi financiada.

No caso da Capitania de São Vicente conforme Eduardo Hoornaert o "ciclo paulista religioso" foi implantado primeiro na região litorânea com a fundação da vila de São Vicente, baseada na cultura do açúcar por Martim Afonso de Sousa e depois no Planalto de Piratininga com a fundação do

50 Neste caso o negro Domingos pagou uma dívida de seu senhor Manoel Fernandes Urtunho e comprou a liberdade de sua filha Sebastiana. Livro de Registros e Escrituras, período 1692-1700, bloco V (1698-1700).

51 John Monteiro, Negros da terra, p.218. 
Colégio de São Paulo, neste processo participaram os franciscanos e jesuítas (1553). Em torno da vila de São Paulo de Piratininga surgiram vários aldeamentos indígenas semelhantes às "encomiendas" do Paraguai. ${ }^{52}$ No entanto o início das tensões começa na região da vila de Santo André da Borda do Campo, onde residia João Ramalho, casado com uma filha do cacique Tibiriçá, cujos filhos já caçavam índios. Daí nasceu a divisão religiosa no planalto paulista : os beneditinos colocavam-se ao lado dos colonos e os jesuítas ao lado dos índios. Depois chegaram os franciscanos e carmelitas, que também se comprometeram com os colonos. ${ }^{53}$

Não residiam portugueses no Campo de Piratininga, exceto João Ramalho e sua família. Viviam no lugar onde agora existe a Fazenda de S. Bernardo, pertencente ao Mosteiro de S. Bento da cidade de São Paulo, meia légua mais ou menos distante da Borda do Campo. O governador Geral Tomé de Sousa, em 1553, mandou criar nela uma vila. Deu João Ramalho cumprimento a estas condições, fazendo a sua custa a trincheira, baluartes, igreja, cadeia e mais obras públicas necessárias. Muito depois de fundada a povoação de Santo André, deram inicio à de São Paulo os padres da Companhia de Jesus, sobre a liderança do Pe. Manoel da Nóbrega ordenando que o Colégio se mudasse da vila para o campo, conservando-se porém em S.Vicente a Casa Antiga, onde os religiosos que lá ficassem dessem o alimento espiritual aos cristãos da marinha. ${ }^{54}$

Desde então, o Colégio de São Paulo (1554) passou a concentrar europeus e cabildas dos Guaianás chefiados por Tibiriçá e Caiubi, cujas moradias foram transferidas, respectivamente das aldeias de Piratininga e Jeribatiba (ou Jaraibatiba) para os arredores do arraial da Companhia de Jesus, em detrimento da vila de Santo André. Isso provocou conflitos entre João Ramalho e o Pe. Manoel de Nóbrega que não aceitava seu modo de viver pois já possuía família em Portugal e mantinha outra aqui, também seu comportamento não era aceito pelos jesuítas por ser semelhante aos dos gentios da terra. Escreve o Pe. Manoel da Nóbrega:

Em este Campo está un Joan Ramallo el más antiguo hombre que hay em esta tierra. Tiene muchos hyjos y muy aparentados en todo este setán (...) es mui conocido y venerado entre los gentiles, y tiene hijas casadas com los

52 A encomienda concedia ao encomiendero, ao colonizador, um grupo de índios, em quantidade variável conforme as regiões e circunstâncias, que eram obrigados a um tributo em dinheiro, espécie, ou trabalho. O beneficiário deveria amparar e tutelar os índios sob sua jurisdição, introduzindo-os na religião católica, quer através de sua própria pregação ou de um clérigo por ele mantido. Conforme Marcel Battaillon, a encomienda se degradou e o lote de índios entregue ao colonizador se transformou numa espécie de arrendamento de gado. (Marcel Battaillon, Études sur Bartolomé de Las Casas). In: Carlos Henrique Davidoff.op.cit., p.38

53 Eduardo Hoornaert. A igreja no Brasil-Colônia (1550-1800),p.62-64

54 Fr. Gaspar da Madre de Deus. Memórias para a Historia da Capitania de S.Vicente, hoje chamada de S. Paulo,p.119-142 
principales hombres desta Capitania, y todos estos hyjos y hyjas son de una índia de los mairores y más principales desta tierra. ${ }^{55}$

Os religiosos conseguiram extinguir à vila de Santo André, fechando e obstruindo à trilha dos Tupiniquins e São Paulo passou a comunicar-se com o litoral pelo caminho do Pe. José (Anchieta) ou do Cubatão.

João Ramalho foi residir longe de São Paulo, entre os índios do Valle do Parahyba. ${ }^{56}$

Além do primeiro aldeamento na região de Piratininga, mais três aldeamentos foram instituídos : São Miguel, Nossa Senhora dos Pinheiros e Itaquaquecetuba todos próximos à vila de São Paulo, abrigando os Tupiniquim e Guaianá. Outro aldeamento jesuítico foi Nossa Senhora da Conceição (1580) , abrigando um grupo de Guarulhos. No litoral vicentino temos o de São João, surgido junto à vila de Itanhaém (1560), sendo habitado por índios Carijó. ${ }^{57}$

O aldeamento originava-se num "descimento" ou "redução" de indígenas do interior da terra para zona litorânea, ou para a confluência dos rios, no caso da região de [São Paulo de Piratininga]. Este descimento sempre era praticado manu militari, sendo um missionário acompanhado pela tropa [ou vice-versa]. Os indígenas "bravos" eram deslocados para às aldeias de "índios mansos", ou "índios da cruz": a cruz no meio de uma praça aberta marcou a existência de um aldeamento e continua até hoje marcando o centro de numerosas cidades e lugarejos. ${ }^{58}$

As reduções jesuíticas se estruturavam em forma de vilas; no centro do aldeamento, erigia-se a igreja e a moradia dos padres. A escola, o

55 Padre Serafim Leite, Cartas, I, p.524. Quanto a acusação de bigamia, permaneceu uma sombra de dúvida, pois Ramalho não sabia se sua mulher em Portugal ainda vivia.

56 Ver Frei Gaspar da Madre de Deus , São Paulo no século XVI, E. Arrault \& Cie., Tours, 1921.

57 J.J. Machado de Oliveira, Notícia raciocinada sobre as aldeias de índios da província de São Paulo , RIHGB,8,1846,p.204-254. Sobre a organização dos aldeamentos em São Paulo Colonial ver também o importante trabalho de Pasquale Petrone, Os aldeamentos paulistas, São Paulo, Edusp, 1995

58 Conforme Beatriz Perrone-Moisés, os "descimentos" tratam-se de convencer os índios do "sertão" de que é de seu interesse aldear-se junto aos portugueses, para sua própria proteção e bem-estar. A obrigatoriedade da presença de missionários junto às tropas de descimento é expressamente estabelecida desde a Lei de 24/02/1587 e reafirmada mesmo quando lhes é tirada a exclusividade na condução dos descimentos (Lei de 1611). O respeito de que gozam junto aos gentios, o conhecimento da língua e o fato de o principal intento do descimento ser a conversão, explicam a importância atribuída à presença de missionários, exclusivamente jesuítas, ou outros como na Lei de 10/09/1611. Conforme o Alvará de 26/07/1596, a Lei de 10/09/1611 e o Regimento das Missões de 21/12/1686 o gentio não poderá dizer que desceu a serra por engano, nem contra sua vontade, os que não forem convencidos não devem em hipótese alguma ser forçados a descer. Mas a ilegalidade da coação ao descimento continuará sendo afirmada até o século XVIII. Beatriz PerroneMoisés.Índios livres e índios escravos.In: Manuela Carneiro da Cunha, op.cit.,p.118. 
armazém geral, a casa de hóspedes e a casa das moças eram mais pobres e os alojamentos indígenas consistiam de longos edifícios de pau-a-pique ou adobe, abertos para uma varanda coberta [conhecido por tijupares, futuras senzalas].

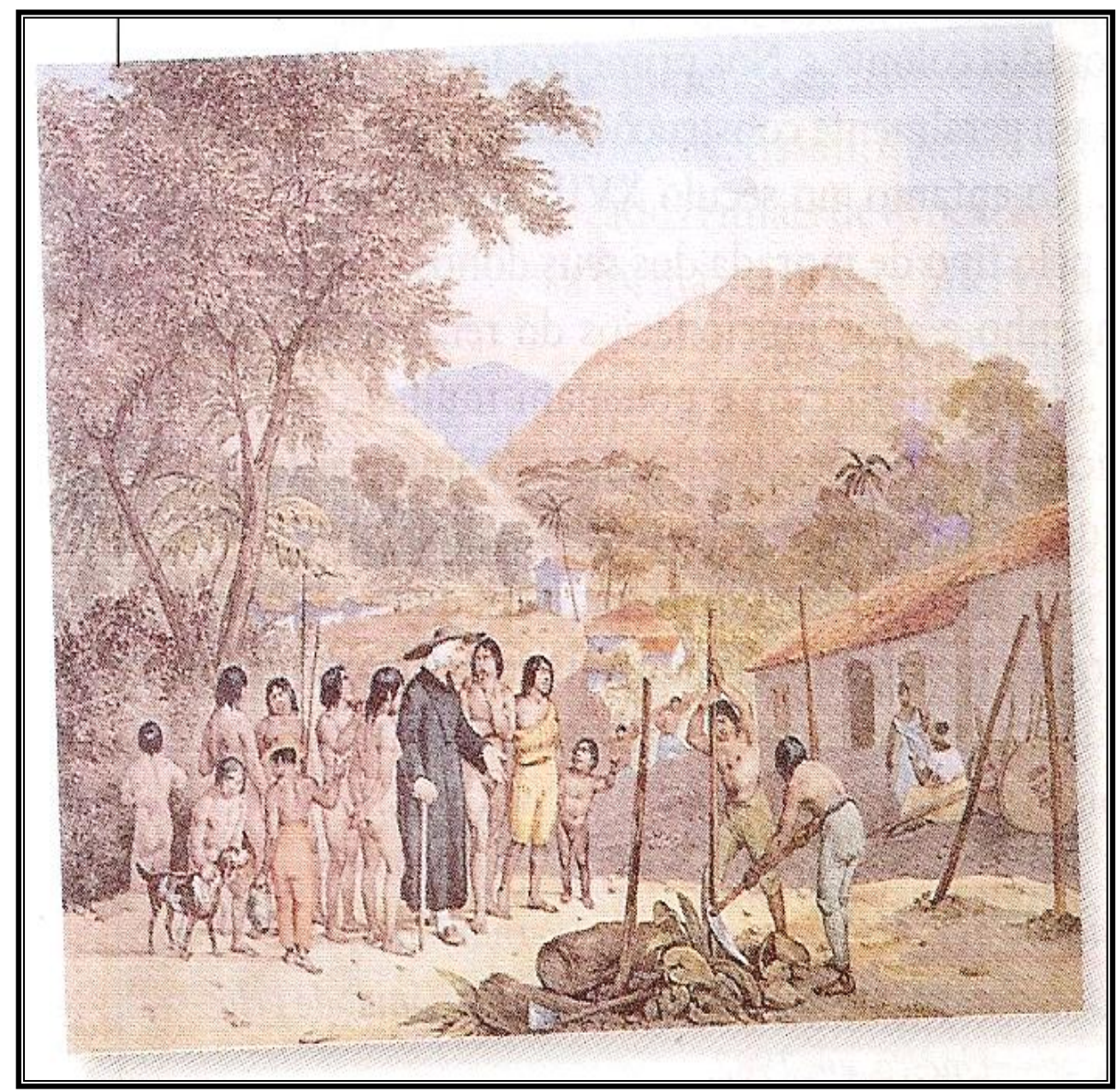

Catequese jesuítica - Aldeia de Tapuias, retratada por Joham Moritz Rugendas (1801-1859)

Quanto à utilização da terra, fazia-se a divisão em lotes, onde as famílias indígenas retiravam seu sustento, depositando a produção no armazém comum. O trabalho era coletivo e a produção visava abastecer toda à comunidade. Os lotes de melhor qualidade eram considerados como tupambae ,"coisas de Deus", neles criava-se gado, fabricavam-se tecidos e plantava-se a erva-mate, produtos negociados pelos padres para a obtenção dos artigos de que necessitavam às missões, como ferramentas, sal e ornamentos religiosos. Nestas missões comportavam as escolas para as crianças indígenas e dos colonos, falava-se o nheengatu (língua geral) uma 
mistura do português e da língua tupi criada pelos jesuítas. Havia oficinas onde praticavam a carpintaria, olaria, cerâmica, tecelagem, pinturas, esculturas, etc. ${ }^{59}$ Com uma mão-de-obra considerada fácil, os "índios mansos" passaram a ser o alvo mais cobiçado pelos paulistas, ocasionando assim vários ataques nas missões jesuíticas. Os padres reclamavam de diversos modos. Padre Vieira argumentava que a arregimentação dos índios pelos jesuítas servia à Fé e à República, ao Cristo e ao Rei, pois aumentava o número dos súditos de Cristo e de vassalos da Coroa. Quanto ao trabalho indígena, Vieira afirma que estes servem à Deus e a si e os jesuítas à Deus e aos índios, e que os colonos interpretavam esta situação "às avessas" dizendo que os missionários exploravam os nativos obrigando-os à servi-los como bem desejarem. ${ }^{60}$

Neste contexto o projeto jesuítico empolgava não apenas os religiosos como também a Coroa e até os colonos, desde que este garantisse mão-deobra abundante e barata. No que diz respeito a região nordeste estes aldeamentos seriam para defesa das ameaças externas - invasões de corsários ingleses e holandeses - e internas abastecendo às lavouras com mão-de-obra de "índios mansos" e defendendo à região dos Tapuias ${ }^{61}$ [

59 Carlos Henrique Davidoff, Bandeirantismo:Verso e Reverso, p.42-43.

60 Ibidem,p.44. Ver conflitos entre paulistas e jesuítas sobre a mão-de-obra indígena nas cartas enviadas à D.João IV, via Conselho Ultramarino, onde os colonos solicitam ser retirada da administração dos religiosos os negros da terra e dada aos moradores da vila de São Paulo, porém, o Conselho não concorda.In: Arquivo Histórico Ultramarino, a partir dos catálogos do Projeto Resgate "Barão do Rio Branco" no que se refere à Capitania de São Paulo. AHU_ACL_CU_023-01, Cx.1, D.14,21 de fevereiro de 1647

61 De acordo com Puntoni, o termo Tapuia foi utilizado primeiramente pelo cronista Gândavo, que assim denominou uma tribo específica de índios que habitavam perto do "rio Maranhão da banda do oriente", e que seriam da mesma nação dos Aymoré, "ou pelo menos irmãos em armas" (Gandavo,História da Província de Santa Cruz,1980:122). Entretanto, mais tarde, "tapuia" passou a designar um conjunto de tribos que, apesar de heterogêneo, era percebido, pelo esquema classificatório, como portador de traços de identidade. A grande distinção originava-se da observação que os povos que habitavam ao longo da costa "tem uma mesma língua (tupi) que é de grandíssimo bem para a sua conversão", nas palavras de Anchieta e acrescenta "pelos matos há diversas nações de outros bárbaros de diversíssimas línguas [Jê, Aruak,etc] a que estes índios [Carijós, Guaianá, Puris, Guarulhos] chamam Tapuia" (José de Anchieta, Cartas, 1988:310) O fato de alguns destes Tapuia não comerem carne humana, a distinção lingüística foi a mais importante. Tratava-se de entender para transformar, compreender as culturas indígenas para substituí-las pelo evangelho. Tupi ou não tupi? Uma contribuição ao estudo da etnohistória dos povos indígenas no Brasil Colônia. In: Antônio Risério (org.) Invenção do Brasil.p.49-55

Para John Monteiro a polaridade Tupi/Tapuia sustentou todo o debate historiográfico em São Paulo, do fim do século XIX início do XX, sobre a identidade dos Guaianá. A imagem idealizada dos antigos povoadores de São Paulo, e portanto os ascendentes dos paulistas, era confrontada com as dos modernos Kaigang. Assim, os Guaianá eram tidos por Tapuia, "uma raça indígena desprezada pela ciência moderna e pelos defensores do progresso", o que causava escândalo e protesto dos defensores de um Tibiriçá tupi. Tupis, Tapuias e a história de São Paulo, Novos Estudos CEBRAP, São Paulo,34;125-135, novembro de 1992. 
índios de nações inimigas dos povos tupis e dos portugueses]. No caso de São Paulo de Piratininga ligando o Vale do Paraíba em direção ao Rio de Janeiro a ameaça externa seria dos corsários franceses e internas dos Tapuias do sertão ( "índios bravos" e aliados dos franceses) contrários ao sistema que a Coroa Portuguesa queria implantar. ${ }^{62}$

Porém, o projeto jesuítico não deu certo. Primeiro, os colonos desejavam negociar os serviços diretamente com os índios, sem haver o padre como intermediário. Reclamavam de várias formas alegando que os religiosos atrapalhavam suas negociações.

Os principais colonos protestaram junto à Câmara Municipal de São Paulo contra a "grande opressão" que sofriam nas mãos dos jesuítas e das autoridades, que impediam a negociação com os índios aldeados (seus "amigos e vizinhos"), solicitando a autorização do capitãomor,freqüentemente ausente da vila. Propunham uma solução, pedindo a Câmara permissão de trazerem "índios mansos para o seu serviço por pouco tempo para poucas coisas", mediante anuência de qualquer vereador, driblando a autoridade do capitão-mor. Esta tentativa não resultou satisfatoriamente, pois os colonos teriam que enfrentar a interferência dos padres nos próprios aldeamentos.

Outro fator, a maioria dos índios recusarem em trabalhar para os colonos [talvez pelos maus tratos], e alguns mesmo aceitando o serviço não concordavam com a forma de pagamento, voltando para os aldeamentos assim que recebiam seus vencimentos, sem cumprir os serviços satisfatoriamente. Essa reação, os colonos atribuíam as influências jesuíticas. ${ }^{63}$

Outro fator muito importante foram as epidemias de varíola que se alastraram pelos aldeamentos, matando vários indígenas. Com altas taxas de mortalidade, foi necessário recompor o plantel com outros grupos indígenas. Estas missões foram caracterizadas pela mistura de povos e culturas, por um lado contribuindo para manter a hegemonia jesuítica e por outro lado, desarticulando a sociedade indígena. ${ }^{64}$

62 Luiz Felipe de Alencastro chamou de "dupla frente militar portuguesa", onde as autoridades coloniais procuram fixar alianças com certas tribos do litoral para barrar a ofensiva dos índios hostis, por um lado, e defender os portos dos corsários europeus, por outro lado". O tratado dos viventes : formação do Brasil no Atlântico Sul, séc.XVI e XVII, São Paulo, Companhia das Letras, 2000.

63 Para melhor análise dos conflitos entre jesuítas e colonos, ver interessante Tese de Doutorado de Joely Aparecida Ungaretti Pinheiro, CONFLITOS ENTRE JESUÍTAS E COLONOS NA AMÉRICA PORTUGUESA(1640-1700), UNICAMP,2007

64 John Monteiro, Negros da Terra,p.47 . Para Manuela Carneiro da Cunha, esse morticínio foi fruto de um processo complexo cujos agentes foram homens e microorganismos mas 
Várias rebeliões entre grupos de nações indígenas diferentes também favoreceu a decadência do projeto jesuítico.

Embora se esforçassem em manter as missões sobre seu controle os jesuítas não conseguiram estruturar este processo. As tradições indígenas falaram mais forte, houve resistência por parte dos Tupiniquim [termo usado para identificar os aliados dos portugueses],Carijó, Guaianá, Guarulhos, entre outros. Os aldeamentos de São Paulo conseguiram criar apenas comunidades marginais de índios debilitados pela doença. Os colonos aproveitam a situação e resolvem intervir no trabalho indígena a seu modo. ${ }^{65}$

O conflito com os jesuítas tornou-se aberto e estes foram expulsos da vila em 1640, só voltando em 1653, com a condição que não se metessem em "negócios de índios e cuidarem apenas do espiritual". Nesta disputa entre jesuítas e colonos a liberdade do indígena e seus direitos não interessavam, o que valia era saber quem teria o direito sobre o trabalho indígena.

cujos motores poderiam ser reduzidos a dois: ganância e ambição, formas culturais da expansão do que se convencionou chamar o capitalismo mercantil.Motivos mesquinhos e não uma deliberada política de extermínio conseguiram reduzir uma população de milhões para pouco mais ou menos 200 mil índios que hoje habitam o Brasil. Nefasta foi a política de concentração da população praticada por missionários e pelos órgãos oficiais, a falta de imunidade, a altitude, o clima, o relativo isolamento, favoreceu as epidemias.[Acrescentamos que uma falta de planejamento mais elaborada por parte das missões e do estado português também favoreceu a dizimação de nações indígenas inteiras.Porém fica claro que o confinamento não foi a solução para "civilizar" os nativos e nem prepará-los para o convívio na Colônia] In:Manuela Carneiro da Cunha.Introdução a uma história indígena: mortandade e cristandade.op.cit.,p.12-13.

65 John Monteiro, op.cit., p.51 


\section{CAPÍTULO 2}

\section{O SERTÃ O: SOLUÇÃO PARA A "POBREZA DOS PAULISTAS"}

O sertão é o "Norte" dos paulistas. Na Ata do dia 7 de janeiro de 1640 o Procurador do Conselho junto aos vereadores decidem requerer ao Ouvidor Geral dizendo que "devasa nesta villa sobre os moradores dela [vila de São Paulo] que forão ao sertão a deser gentio e porquanto ate o presente estava em huzo e costume irse ao sertão por os moradores não poderem viver sem o sertão [grifo nosso]. ${ }^{1}$ Porém nas incursões e entradas para o sertão , o braço indígena era o elemento primordial, ele representava o número, a habilidade, a agudeza, a orientação , o segredo, o sucesso dessas empreitadas. Era ágil, sadio quando em liberdade, descobria recursos para a sobrevivência e conhecia os caminhos e esconderijos dos outros índios considerados seus contrários. Caçava-se assim o índio com o próprio índio. ${ }^{2}$

Sergio Buarque de Holanda destaca que os adventícios habituaram-se às soluções e muitas vezes aos recursos materiais dos primitivos moradores da terra. Para o sertanista branco ou mamaluco ${ }^{3}$, o incipiente sistema de viação que aqui encontrou foi um auxiliar tão prestimoso e necessário quanto fora para o indígena. Revelam suas afinidades com o gentio da terra, mestre colaborador inigualável das entradas, sabiam os paulistas como transpor pelas passagens mais convenientes as matas espessas ou as montanhas aprumadas, e como escolher sítio para fazer pouso e plantar mantimentos. ${ }^{4}$

1 ACSP, 1640 , p. 8 e 9.

2 Theodoro Sampaio, São Paulo de Piratininga no fim do séc.XVI, RIHGSP,v.4,p.268,1899. Vera Lúcia Amaral Ferlini, chama a atenção quanto a figura do capitão-do-mato, na caça aos escravos negros [africanos e indígenas] fugidos.Os escravos negros africanos viam no índio [aliado] um inimigo. Os índios, europeizados nos aldeamentos, de conquistados, passam a ser um agente dos conquistadores. A civilização do açúcar.Séculos XVI a XVIII,p.57

3 Capistrano de Abreu comenta que os jesuítas chamam à gente de São Paulo mamalucos, isto é , filhos de cunhas índias, denominação evidentemente exata, pois mulheres brancas não chegavam para aquelas brenhas.Capítulos de História Colonial, p.100

4 Sergio Buarque de Holanda, Caminhos e fronteiras, p.19. 


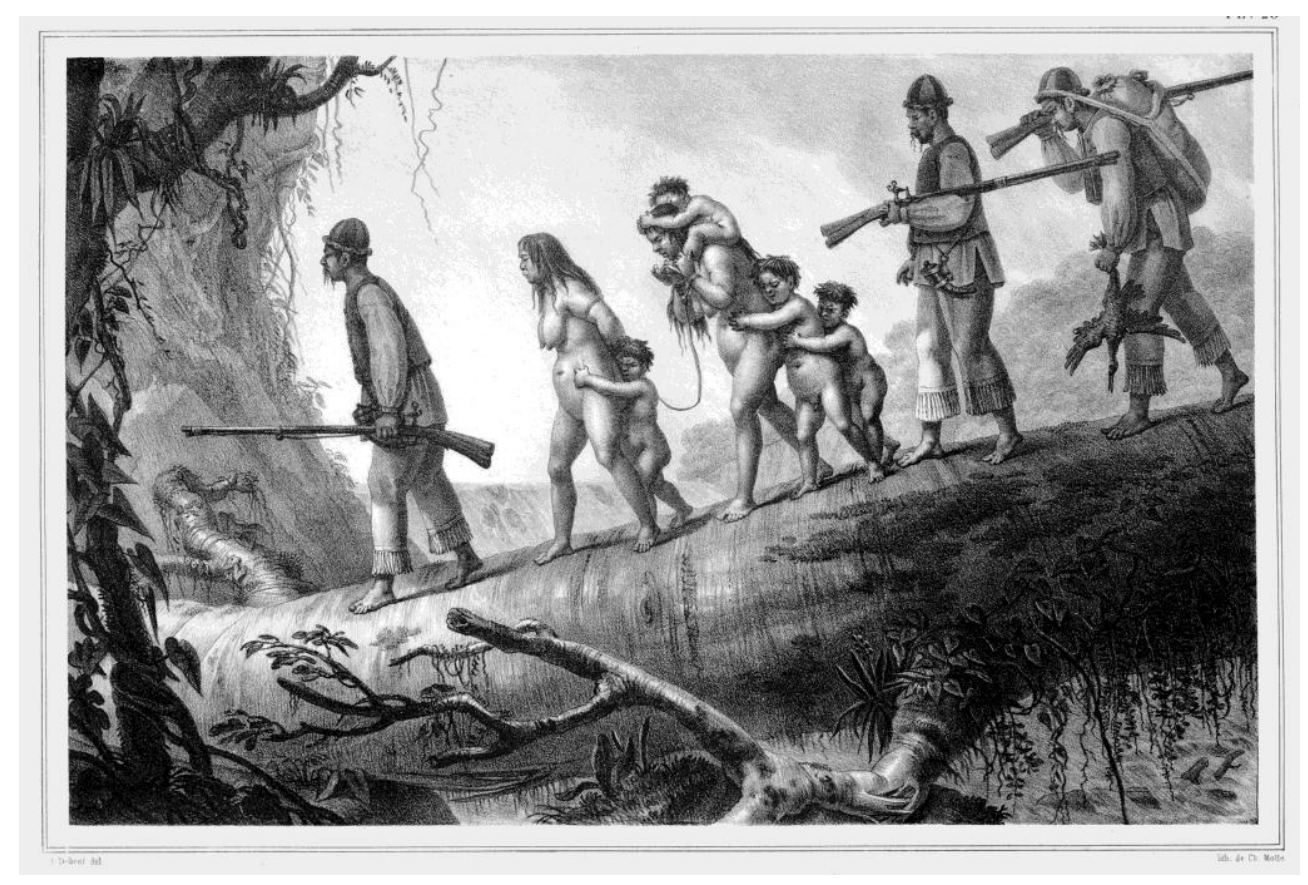

"Sauvages civilisés soldats indiens de la province de la Coritiba, ramenant des sauvages prisonnières", litografia em J. B. Debret, Voyage pittoresque au Brésil, 1834

Tal como no século XVI, as relações de troca e as alianças com nações indígenas [chamados de intermediários] favorecem a idéia central dos conquistadores europeus em buscar cativos no sertão dando preferência aos cativos Guarani [que falavam tupi], por falta de experiência era necessário que o auxílio do índio fosse primordial para que as incursões de apresamento fossem satisfatórias.

Razões econômicas, sociais e mentais, fizeram do indígena presença mais que necessária no Planalto de Piratininga, tornando-se, [na expressão de Antonil], "as mãos e os pés" [do paulista]. Os descimentos, resgates e as expedições sertanistas, principalmente, forneceram à região Planaltina um número elevado de silvícolas para as necessidades da região. ${ }^{5}$ Mas com as dificuldades encontradas com os aldeamentos jesuíticos, os custos elevados no montar uma "grande armação" houve a necessidade de se repensar o projeto das incursões sertanejas. Com o passar do tempo, os Guaranis localizavam-se em áreas cada vez mais distante. As tribos Guaianás e Guarulhos, que se concentravam próximas à São Paulo, apesar de fornecerem mão-de-obra para a região, não eram suficientemente numerosas, resistiam bravamente à escravidão, além de não conhecerem a 
língua geral. ${ }^{6}$ Assim, a expansão econômica paulista requeria um número cada vez maior de indígenas. Sem capital e sem maior acesso a créditos, os paulistas reconheciam a impossibilidade de importar escravos africanos em número considerável para suas lavouras, favorecendo o aumento de cativos indígenas. A serra do Mar, foi outro obstáculo encontrado, o transporte das mercadorias para o litoral era difícil e caro, principalmente para produtos que não possuíam valor elevado.

Como mostra o mapa (figura 1), a partir da década de 1640, as expedições de grande porte cederam lugar a novas formas de organização do apresamento. Com a falta de cativos Guarani, às expedições paulistas passaram a introduzir outros grupos indígenas como Guaianás, Guarulhos, Puris, Coroados, Carijós, Tabajaras, Cataguás [que falavam Tupi e Jê] e os que encontrassem como solução para a crise de mão-de-obra. Esta busca terá como conseqüência o extermínio e a escravidão de nações indígenas consideradas inimigas conhecidas como Tapuias. Ao mesmo tempo, estas armações passaram a se fixar nas terras do sertão valeparaibano no intuito de conquistar a região, formando pequenos núcleos de abastecimento para as expedições e armações que buscavam à exploração dos minérios na serra de Sabarabuçu. Assim diversas expedições penetraram nos sertões do Vale do Paraíba, favorecendo a fundação na região de novas vilas por pioneiros paulistas, sendo que nos anos 1640-50 foram instalados pelourinhos em Taubaté(1640), Guaratinguetá(1651) e Jacareí (1653). Ao mesmo tempo, exploradores da vila de Parnaíba trilharam os sertões para o Oeste e Sul. A Noroeste, colonos de São Paulo fundaram a vila de Jundiaí (1655). ${ }^{7}$

Necessário se faz ressaltar que os paulistas não vendiam para o Nordeste açucareiro a maior parte do gentio apresado, como a historiografia tradicional retrata, mas se preocupavam em aprofundar o dinamismo interno da vila paulistana e seus arredores. A historiografia mais recente discute o processo de expansão econômica e de mercantilização da região. John Monteiro pondera que os altos custos do transporte para região nordestina, às poucas possibilidades de sobrevivência e as restrições legais à escravização indígena tornavam o tráfico uma proposição econômica pouco interessante, limitando-o à transferência de pequenos grupos ou de indivíduos cujo valor justificasse o custo da viagem e que a maioria dos índios capturados era integrada à economia florescente do planalto. Os portugueses da Bahia organizaram expedições de apresamento semelhantes

6 John Monteiro, São Paulo in the seventeenth century: economy and society, p.107-11.

7 ibidem, p.81-82. 
àquelas que saíam de São Paulo, ainda que sem produzir os mesmos resultados. Ao que parece, durante o século XVII uma parte significativa da mão-de-obra indígena recrutada para a lavoura canavieira provinha do Maranhão. ${ }^{8}$

As expedições que buscaram cativos Guaianá e Guarulhos tiveram como resultado profunda alteração da composição étnica da população cativa. Os Guarani continuavam a compor a maioria absoluta da população paulista, apesar de compartilharem os tijupares com as outras nações indígenas. A nova situação terá conseqüências graves no que diz respeito ao controle social nas fazendas paulistas, rebeliões e fugas aumentaram a partir de 1650, fato ligado a questão étnica; revoltas de Guaianás e Guarulhos não aceitando a submissão fogem para o sertão. A solução reorganizar e aumentar as expedições de apresamento em busca do "remédio para suas lavouras".

Mas o apresamento de indígenas não era somente a preocupação dos colonos da vila de São Paulo, as rotas de comércio deveriam ser melhoradas para facilitar não só a organização das armações para o sertão como para ampliar o comércio com as demais vilas e áreas litorâneas. Este desenvolvimento mercantil fez com que São Paulo assumisse uma posição hegemônica sobre os demais núcleos, fortalecendo-se em relação às outras vilas e povoados locais.

\subsection{Criar e recriar caminhos para o sertão}

Os estudos sobre os caminhos ligando à vila de São Paulo ao sertão no período seiscentista fora por muito tempo desconhecidos, porque a Coroa Portuguesa proibia a divulgação desses caminhos, local onde existiam minas de ouro e prata. Na medida em que surgiram as primeiras minas de ouro na região dos sertões dos Cataguás em fins do século XVII e início do XVIII, o governo português intensificou a fiscalização para se evitar o desvio de ouro e de pedras preciosas pelos "descaminhos", mesmo assim o contrabando continuou, lesando o pagamento do "quinto" de imposto.

Miriam Ellis comenta que São Paulo de Piratininga é um centro de entroncamento de passagens naturais.[Observadas pelos jesuítas e pelos colonos vicentinos com relação as vantagens da posição geográfica do local incluindo os rios Tietê, Paraná e região do Prata]. Para ela três grandes

8 Idem, Negros da terra, p.78 
passagens partem de São Paulo, seguindo as linhas do relevo que condicionam as diretrizes da expansão paulista :

1. a passagem rumo nordeste, pelo Vale do Paraíba, rota das expedições para Minas Gerais, para o rio São Francisco, para o norte e nordeste do Brasil;

2. a passagem para o norte, por Campinas e Moji Mirim, em direção a Minas Gerais e Goiás.

3. a passagem em direção ao sul e sudoeste, via Sorocaba e Itapetininga visando as regiões meridionais. ${ }^{9}$

E acrescentamos com grande importância o Caminho do Mar (São Paulo - Santos), que favorecia o comércio de gêneros alimentícios, de gado e de artigos importados. A preocupação de manter esses caminhos encontramos em várias Atas da Câmara da Vila de São Paulo, como segue:

Proveo mais o dito ouvidor geral que logo e com efeito se fixassem quartéis pêra que os moradores facão o caminho do mar com pena de quatro mil réis aplicados pêra o conselho e cativos aos quaes se executarão logo por seus bens tanto que constar que foram rebeldes e não obedeserão e que daqui em diante com muito cuidado se faça todos os anos o dito caminho pontes e terrados com vigas e paus fortes e se façam outrosi as mais pontes fortes e caminhos e serventias desta villa sob a mesma pena que se executara e os officiaes da câmera assim madaram dar a execuzam sob pena de as pagarem de sua caza. ${ }^{10}$

Com o passar do tempo, e a crescente mercantilização da vila, houve a necessidade de melhorar os caminhos para outras regiões da Capitania.

(...) e logo por elles [vereadores e juiz] foi dito ao procurador do conselho simão róis coelho que se tivese que requerer o fizesse e logo pelo dito procurador foi requerido aos ditos ofisiais que se mandase pasar quartel pêra que fizesem os caminhos dos bairros de comum e pontes. ${ }^{11}$

O escoamento da produção, o apresamento indígena e sua comercialização entre os colonos vicentinos, o comércio e as articulações com outras vilas e a área litorânea, favorecerá à busca pelos metais preciosos e ao mesmo tempo manterá suas fazendas em produção.Assim criam e recriam caminhos.

Era importante a conservação das rotas de comércio que nas décadas do século XVII passa a desempenhar forte ligação com o sertão. Eram essas pontes, caminhos e aterrados que facilitavam tanto o acesso quanto as saídas

9 Miriam Ellis. As bandeiras na expansão geográfica do Brasil. In: Sergio Buarque de Holanda, História Geral da Civilização Brasileira, op.cit.,p276 e seg. Também a respeito destes caminhos ver Caio Prado Jr. O fator geográfico na formação e no desenvolvimento da cidade de São Paulo. In: Evolução Política do Brasil e outros estudos, 1975.

10 ACSP, 21/11/1646,p.278

11 ACSP, 09/02/1647, p.293 
da vila, permitindo uma melhor articulação com os bairros e demais núcleos de povoamento, elemento vital para o desenvolvimento do comércio paulistano. A vila de São Paulo deixa de ser isolada e passa ser um entroncamento de várias vias ligando em especial os sertões do Vale do Paraíba com a região mineradora e o Rio de Janeiro ( via Parati).

Como já mencionamos a Coroa Portuguesa na figura de D. Francisco de Sousa incentivava os colonos nas entradas para o sertão com objetivo de encontrar minas de ouro, mas ao retornar muitas destas expedições voltavam com cativos indígenas sem nenhuma riqueza mineral. Como nos relata um fato da Câmara Municipal de São Paulo de 16 de fevereiro de 1647.

“ (...) foi requerido aos ditos oficiais que mandassem passar precatórios para as câmeras das capitanias debaixo para que não deixem sair para nenhuma pessoa o sertão nem lhe dessem mantimentos nem favor nem ajuda porquanto vão a buscar o gentio e não ao descobrimento da prata" ${ }^{12}$

Vários colonos que participaram das expedições para o sertão acreditavam em enriquecer rapidamente, mas muitos aproveitaram a oportunidade para expandir suas posses de escravos.

Muitos destes caminhos e trilhas provavelmente foram criados pelos indígenas e essas rotas foram aos poucos sendo passadas para os armadores e sertanistas de São Paulo. Orville Derby analisa um caminho percorrido pela entrada de André de Leão em 1601 (que durou nove meses). O itinerário desta expedição foi revelado na História Naturalis Brasiliae, de Piso e Marcgraf, publicada em 1648, que inseriu um relato do holandês Willem Jost Ten Glimmer que dela participou como mineiro prático. Provalvemente este caminho também foi utilizado por Fernão Dias Paes em 1674 e outros sertanistas. ${ }^{13}$ Esta expedição para o sertão conhecida como "Caminho Velho", foi organizada em São Paulo no tempo da administração de D.Francisco de Sousa. Acreditamos ser importante reproduzir esta rota de Glimmer para o sertão, pois foi o caminho mais utilizado pelas entradas paulistas rumo à região mineradora:

Partindo da cidade de São Paulo, na Capitania de São Vicente, chegamos, primeiroa povoação de São Miguel, a margem do rio Anhembi [Tietê] enesse logar achamos preparadas as provisões que os selvagens

\section{ACSP, 1640-1652, p.294}

13 Orville A. Derby. O Roteiro de uma das Primeiras Bandeiras Paulistas.RIHGSP, v.4, p. 329-350,1899. Ver também João Antonio (Antonil) Andreoni. Roteiro do caminho da vila de São Paulo para as minas gerais e para o rio das Velhas em Cultura e Opulência do Brasil por suas drogas e minas (1711) 2 ed. São Paulo, Ed.Nacional,1966.p.181-186 e Capistrano de Abreu, Caminhos antigos e povoamento do Brasil, Civilização Brasileira, 1975. Ver texto em holandês em Willem Piso, História naturalis brasilliae...Lugdun Batavorum apud F. Hackium et amateledami apud L. Elzeviviriam,1648, v.2, p.263-264. 
tinham de carregar nos hombros. Atravesssámos, depois, aquelle rio e, com uma marcha de quatro ou cinco dias a pé, através de densas mattas, seguimos rumo de Norte, até um riacho que nasce nos montes Guarimumis ou Marumiminis, região de Itapety próxima a Mogi das Cruzes) onde há minas de ouro. Aqui apparelhadas algumas canoas de cascas de arvores, continuamos rio abaixo, durante cinco ou seis dias, e fomos ter a um rio maior [região da foz do rio Jaguary, em frente a atual cidade de São José dos Campos] que corria da região occidental. Aquelle primeiro riacho deslisa por sobre campos baixos e humidos, notáveis por sua amenidade. Tendo descido este rio maior, em dois dias, encontramos outro ainda muito maior, que nasce no lado septentrional da serra de Paranapiacaba (o Anhembi nasce no lado autral da mesma serra), e correndo, a principio, para o Occidente, na mesma direcção dos montes, depois formando um cotovello, se encaminha por algum tempo para o Norte, e, afinal, como geralmente se crê, se lança no Oceano, entre o Cabo Frio e a Capitania do Espírito Santo; chamam-n'o de Sorobis [Rio Paraíba do Sul] e é abundantíssimo em peixes, tanto grandes como pequenos. Descendo também este rio, durante quinze ou dezeseis dias, chegamos a uma cataracta, onde o rio, apertado entre montanhas alcantiladas, se despenha para o Nascente[ região da atual cidade de Cachoeira Paulista]. 


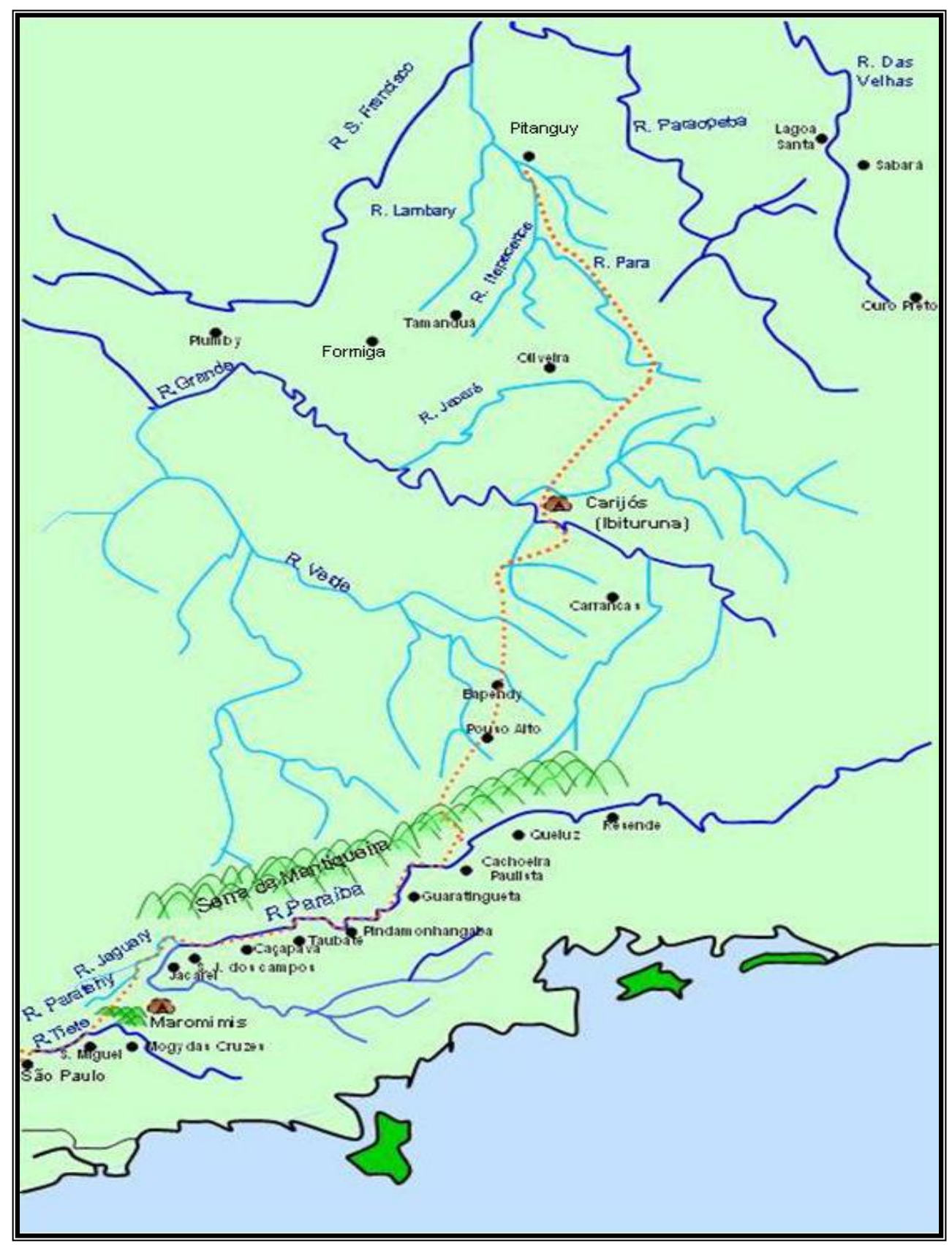

Reconstituição do itinerário de Glimmer / Bandeira de André de Leão 1601 
Por isso, abicamos neste ponto as nossas canoas e marchamos outra vez a pé, ao longo de outro rio que desce do lado occidental e não presta a navegação [provavelmente era o rio Passa Vinte, que desce a garganta que depois serviu de passagem da estrada dos mineiros e hoje para a estrada de ferro Minas e Rio de Janeiro]. Com cinco ou seis dias de marcha, chegamos a raiz de um monte altíssimo, e, transpondo-o descemos a uns campos mui descortinados e aqui e acolá sombreados de bosques, nos quaes se vêem lindíssimos pinheiros, que dão fructos do tamanho de uma cabeça humana; as nozes desses frutos tem a grossura de um dedo médio e são protegidas por uma casca, como as castanhas, e são mui agradáveis ao paladar e nutritivas.[Provavelmente eram árvores da Araucária, cuja fruta é o pinhão consumida até hoje \}Por muitas milhas no interior se encontram árvores desta espécie.

Três dias depois, chegamos a um rio, que deriva do Nascente, e, atravessando-o, durante quatorze dias [provavelmente região do rio Angahy] , tornamos a direcção do Noroeste, através de campos abertos e outeiros despidos de arvores, até outro rio, que era navegável e corria da banda do Norte [Provavelmente região do rio Grande]. Atravessámol-o numas embarcações chamadas jangadas, e, quatro ou cinco léguas mais adeante, topamos outro rio que corria quase de Norte e era navegável [possivelmente rio das Mortes]. Creio, porém, que estes rios, afinal, confluem num só leito e vão desaguar no Paraguay, em razão de que o curso delles é para o Sul, ou para o Occidente. Em toda a viagem até aqui descripta nada vimos que denotasse cultura, não encontramos homem algum, apenas aqui e alli aldeias em ruínas [tribos nômades], nada que servisse para alimentação, além de hervas e algumas fructas sylvestres; todavia, observávamos as vezes fumaça, que se erguia no ar, pois por aquellas solidões vagueavam com suas mulheres e filhos alguns selvagens, que não tinham domicilio certo e não curavam de semear a terra [caçadores-coletores]. Junto a este ultimo rio, encontramos, finalmente, numa aldeia de indígenas [trecho junto a estação de Aureliano Mourão, na estrada de ferro Oeste de Minas e poucos quilômetros abaixo da povoação de Ibituruna, onde Fernão Dias estabeleceu um dos seus postos], víveres em abundancia, que vinham muito a proposito, visto que já estavam consumidos os que comnosco tínhamos trazido, e já a fome nos obrigava a comer fructas sylvestres e hervas do campo.

Tendo-nos demorado aqui quase um mez, abastecidos de vitualhas [víveres], proseguimos a nossa viagem em rumo de Noroeste e, decorrido um mez, sem encontrar rio algum, chegamos a uma estrada larga e trilhada e a dous rios de grandeza diversa [possivelmente os rios Jacaré e Pará], que, correndo do Sul, entre as serras Sabaraasu, rompem para o Norte [esta região pertence ao espigão entre o Rio Grande e as cabeceiras dos rios Pará e São Francisco]; e é minha opinião que esses dous rios são as fontes ou cabeceiras do Rio São Francisco. Da aldeia sobredita até estes rios não vimos pessoa alguma, mas soubemos que além das montanhas vivia uma tribu de selvagens assas numerosa. Estes, informados (não sei como) da presença de europeus naquelles sítios, despacharam um dos seus para nos espreitar. Cahindo este em nosso poder, demo-nos pressa em arripiar carreira, de medo desses bárbaros e por nos escassearem os víveres, ficando por explorar o metal por cuja causa havíamos sido mandados; e, quase mortos de fome, voltamos aquella aldeia de selvagens [povoado de Ibituruna].

Dahi, recuperadas as forças e apparelhados os víveres, pelo mesmo caminho por onde viéramos regressamos aquelle rio, onde havíamos deixado as canoas [região de Cachoeira Paulista], e, revigorados, saltamos nellas e 
subimos o rio até as suas fontes; e assim gastos nove mezes nesta expedição, voltamos primeiro a Mogomimin, depois, a cidade de São Paulo. ${ }^{14}$

Era importante o "caminho do Norte", ou "para o Norte". Este "caminho velho", "trilha dos índios", servirá para outras expedições ligando a região de São Paulo - Vale do Paraíba - Sertão dos Cataguás (região mineradora) . Dentro da questão da reorganização do apresamento indígena, surgiram povoados ou pontos de passagem forçada, como postos de abastecimentos para as armações em direção da região mineradora, estes povoados transformaram os sertões de Taubaté e os sertões dos Cataguás em futuras vilas, unidades produtivas que fortaleceram a mercantilização com a cidade de São Paulo . Desde os primeiros anos do século XVII foi este caminho o mais freqüentado pelos paulistas, até o aparecimento do "caminho novo de Garcia Rodrigues" via Rio de Janeiro.

Considerando que o Vale do Paraíba desde 1624, estava integrado na Capitania de Itanhaém, encontra-se também quanto à sua localização a justificativa adequada para designá-lo de Norte. Com relação ao "Caminho Novo" de Garcia Rodrigues, podemos relacionar como um reflexo da mercantilização, através da concessão de monopólio da venda de produtos necessários para abastecer uma armação, em troca da abertura de caminhos mais rápidos e seguros para as regiões mineratórias. Assim, Garcia Rodrigues Pais, filho de Fernão Dias Pais, comprometeu-se a construir o "Caminho Novo" para às minas e obteve do governador Artur de Sá e Menezes, a monopolização mercantil do dito caminho por dois anos, a contar de junho de 1700, em 1702, obteve o cargo de guarda-mor das minas. ${ }^{15} \mathrm{O}$ interesse da Coroa Portuguesa neste novo caminho era grande, o principal motivo era evitar os "descaminhos" do ouro e do quinto real, Garcia Rodrigues sai favorecido quando recebe sesmarias nas rotas do dito caminho. Ali estabeleceu roçados de mantimentos e vendas. Antonil descreve em seus roteiros para às minas tanto saindo de São Paulo como do Rio de Janeiro, todos os caminhos davam nas roças de Garcia Rodrigues e suas vendas. ${ }^{16}$

O "Caminho Novo" será concluído em 1725, por Bernardo Soares de Proença, onde D.João V recusa a concessão de novas sesmarias naquela rota

14 Orville A. Derby. O Roteiro de uma das Primeiras Bandeiras Paulistas.RIHGSP, v.4, p. 329-350,1899.

15 Ver Pedro Taques de Almeida Paes Leme, Informação sobre as minas de São Paulo, p.150-151.

16 Ver João Antonio Andreoni (Antonil). Cultura e opulência do Brasil por suas drogas e minas,p.184-186. 
à Garcia Rodrigues, alegando, justamente, que ele não cumprira o prometido. $^{17}$

Novos e velhos caminhos entrecruzavam-se na região paulista, articulando gêneros alimentícios, gado, mercadorias importadas, abastecendo tanto a região do Planalto como os territórios auríferos das Minas Gerais e de Cuiabá. Com a expansão da teia mercantil paulistana, os arrendamentos dos contratos e dos direitos de passagem tornaram-se cada vez mais rentáveis, sendo monopolizados nas mãos da elite local. ${ }^{18}$

\subsection{A criação de uma força de trabalho no sertão: "a cura para sua pobreza"}

O bandeirismo foi o maior movimento de penetração no interior, que só em sua fase final, motivada pela procura de minerais, se estabilizou, criando vilas, povoando o interior, cultivando gado. Toda a expansão geográfica no Brasil fez-se em torno das bandeiras. As entradas são consequiências da fase das expedições geográficas e têm, assim, objetivos de reconhecimento do território e de seus recursos minerais. As bandeiras não tinham, inicialmente, nenhum fim político de alargamento do território. Iam os bandeirantes buscar homens, aonde os achavam e não para ocupar a terra e povoá-la. Ligam-se umas às outras, numa cadeia una e indissolúvel, porque reconheciam a terra, e caçavam o índio, indispensável como mão-deobra, onde o negro [africano] ainda não fora importado suficientemente, ou procuravam o ouro e os diamantes, sedução que sempre os impulsionou, desde as primeiras horas. Partidas de homens empregados em prender e escravizar o gentio indígena, as bandeiras até 1640 [ e após esta data] mais devastam, depredam e despovoam que fixam, povoam e incorporam. ${ }^{19}$

Até 1640, os sertanistas paulistas satisfizeram suas necessidades com grandes cargas de cativos Guarani, acompanhando de perto a expansão da agricultura comercial no Planalto de Piratininga. Com a interrupção do abastecimento de cativos Guarani a partir desta data com a epidemia de varíola que se abateu sobre o planalto piratiningano na década de 1660, surgiu uma crise local, obrigando praticamente os colonos a modificarem suas estratégias de apresamento, desenvolvendo novas formas de organização para as expedições sertanejas.

17 Provisão-régia ordenando ao governador do Rio de Janeiro que agradecesse ao sargentomor Bernardo Soares de Proença o ter aberto o caminho novo das minas à própria custa, em Basílio de Magalhães, Expansão geográfica do Brasil colonial,p.326-7.

18 Ilana Blaj, A trama das tensões,p.276

19 José Honório Rodrigues. História da História do Brasil, p.113 
Em direção ao sertão, os paulistas começam a organizar pequenas expedições [armações na linguagem da época], cujo objetivo era atender à demanda específicas por mão-de-obra. Ao contrário das grandes bandeiras, estas novas expedições serviam sobretudo para a reprodução das próprias unidades de produção. Embarcando em viagens para o interior, muitos jovens redigiram ou ditaram seus testamentos, manifestando a necessidade de penetrar no sertão para "buscar remédio para minha pobreza". Durante o século XVII, "a cura", "o remédio" que era tão procurado foi o cativo indígena. O jovem colono dependia dessas "peças" para iniciar suas atividades produtivas, bem como ter uma fonte de renda. No contexto econômico de São Paulo seiscentista, um jovem colono para se sobressair dependia de um dote vantajoso, ou do recebimento de uma boa herança, ou até participar de uma rentável expedição de apresamento. Para a maioria dos colonos que buscavam estabelecer-se na sociedade local, a opção do apresamento representava a maneira mais oportuna de constituir uma base produtiva de alguma envergadura. ${ }^{20}$

Geralmente, os jovens que partiam em busca de cativos recebiam ajuda de custo de seus pais ou sogros, que investiam pequenas somas de capital e alguns índios nas expedições, com o interesse em expandir suas próprias posses. Os armadores, que forneciam dinheiro, equipamentos e índios, assumiam todo o risco da viagem em troca da perspectiva de ganhar metade dos cativos presos. A armação era um empreendimento familiar. Esses acordos entre pais e filhos geralmente eram fechados verbalmente. Nessas expedições participavam um ou mais sertanistas experientes, que conduziam vários jovens colonos em sua primeira viagem ao sertão.

Declaro que tenho uma armação com Antonio da Costa no sertão que lhe dei dois negros e uma corrente de quatro braças e meia como dez colares e uma canoa e uma arroba de chumbo com sua pólvora e tudo mais necessário para partirmos entre ambos pelo meio o que Deus der de que tenho papel em meu poder. $^{21}$

Com relação a vila de Taubaté temos o testamento de Domingos Gomes da Costa que patrocinou a armação de seus filhos para o sertão acreditando ser este o "remédio" para a cura de seus problemas.

Declaro q' tenho dous filhos no serttam Manoel de Goys e Gabriel de Góis por minha conta, easim trazendo os.... salvamento com remédio entrarã tudo no montemor para se fazer partilhas entre todos os meus erderos, e conforme as pessas que trouxerem de cada duzia lhe darã três de seu trabalho. ${ }^{22}$

20 John Monteiro, Negros da Terra, p.86

21 Testamento de Antonio de Oliveira Cordeiro,Jundiaí,1711,AESP-INP,cx.24.

22 Testamento de Domingos Gomes da Costa, 1671, DMPAH,cx.1,doc.39 
Na segunda metade do século XVII vários contratos entre as partes aconteceram, pois as expedições também recebiam apoio material de outras fontes. Os melhores exemplos de tais acordos provêm dos documentos da Ordem dos Carmelitas, pois, em diversas ocasiões, os religiosos do convento forneceram índios,provisões e até dinheiro a sertanistas que cativassem escravos indígenas.

Aos 28 dias do mez de dezembro de 1648, n'este convento de Nossa Senhora do Carmo da villa de São Paulo, juntos todos os religiosos em capítulo, propôz o reverendo padre-prior d'elle, frei Ângelo dos Martyres, que, vista a limitação dos bens deste convento, e que o remédio d'elle depende do serviço dos índios, dos quaes o convento vai tendo grande falta, o que, visto lhe parecia que convinha mandar alguns moços ao sertão arrimados a um homem branco, pagando-se-lhes tosos os gastos e aviamentos necessários. E logo todos os religiosos una voce responderam que era da melhor conveniência para bens do convento. Em fé do que se fez este termo, que todos assignaram --- Fr.Angelo dos Martyres,prior, Fr.Balthazar do Rosário, Fr.Joao das Chagas, Fr.Manoel de Santa Catharina, Fr.Domingos da Luz, Fr.Manoel de Sant'Anna, Fr.Christovão de Jesus, Fr.Antonio da Cruz. ${ }^{23}$

No ano de 1650 houve outras incursões patrocinadas pelos religiosos da Ordem Carmelita, outro contrato interessante data do ano de 1662 , onde os carmelitas determinaram que "por falta de gente que tinham as fazendas, nos importava mandar ao sertão 8 moços em companhia do capitão José Ortiz de Camargo [este foi o promotor da guerra entre as famílias Pires e Camargo], para que com o favor de Nossa Senhora pudessem trazer alguma gente, pois sem ella se acabariam totalmente, não só as fazendas, mas o convento, escolhemos 4 moços da fazenda de São Pedro e 4 da fazenda de Embiacica, e os enviamos para com o dito capitão José Ortiz de Camargo" ${ }^{24}$

A religiosidade dos sertanistas, a preocupação com a doutrinação e batismo dos novos cativos indígenas, a dificuldade em entender o idioma de outras nações indígenas levou a solicitar a presença de um religioso nas incursões:

Querendo nós Jeronymo de Camargo, Antonio Bueno e Salvador de Oliveira e os mais companheiros que n'esta jornada, que intentamos fazer viagem para o sertão como foi costume, e é dos moradores da villa de São Paulo, e os mais a ella aggregados, como filhos da igreja, querendo nos fazer jornada para melhor conseguirmos nosso intento como tementes à Deus, concordamos todos que para effeito de nosso intento nos pareceu que a não faríamos como desejamos senão levando em nossa companhia um sacerdote para nos administrar os sacramentos necessários para salvação de nossas almas [grifo nosso], e pedimos por isso ao padre frei Francisco da Conceição, prior do convento de Nossa Senhora do Carmo, se tinha alguns

23 Arquivo do convento do Carmo de São Paulo, maço que tem por título - Decisões do convento. In: Manuel Eufrásio de Azevedo Marques. Apontamentos, p.341

24 Ibidem,p.342 
religiosos sacerdotes para mandar em nossa companhia, o qual nos respondeu que, além dos que desejavam se sacrificar no serviço da reducção das almas, tinha o padre frei João de Christo, religioso professo, sacerdote approvado, que com boa vontade se offerecia para fazer este serviço a Deus e à religião, e que faria disto por commissão que tinha de seu muito reverendo padre frei Alberto do Espírito-Santo, provincial de sua ordem.

$\mathrm{O}$ que visto por nós adiante nomeados e assignados promettemos e nos obrigamos que das primeiras cem peças que Nosso Senhor for servido darnos, daremos ao dito padre frei João de Christo a metade, e das outras que mais se adquirirem faremos com elle partilha como aos mais soldados da bandeira. [grifo nosso]. E para darmos satisfação a isto assignamos hoje três de maio de 1685. - Fr. Francisco da Conceição, prior.-Jeronymo de Camargo - Antonio Bueno - Salvador de Oliveira. ${ }^{25}$

Além dos colonos e padres, a participação de índios nessas expedições foram importantes, naturalmente conheciam "os caminhos" do sertão e suas dificuldades. Nas armações mais curtas, os sertanistas alimentavam-se da caça e da coleta de frutas e mel. Quanto mais longas estas viagens, eram estabelecidos pequenos arraiais ou roças, situados em pontos estratégicos, de forma que pudessem abastecer toda a expedição. Provavelmente, alguns desses arraiais foram o embrião das futuras vilas e povoados direcionados para a região das Minas Gerais, Goiás e Mato Grosso.

O abastecimento de roças no caminho do sertão representava uma inovação na organização do apresamento e também na prospecção de minérios e diamantes, por isso não compensava investir em grandes e longas incursões pois o custo e o tempo envolvidos nas armações passaram a ser melhor calculados, ficando as grandes incursões para os sertanistas mais abastados.

25 Ibidem,p.342 Interessante notar que no início da formação da vila de São Francisco das Chagas de Taubaté, participou das armações junto ao capitão Jacques Félix o frei Antonio da Cruz pertencente a Ordem de Nossa Senhora do Carmo. O "Convento Velho" assim chamado depois da construção do Convento Franciscano em 1674 "tinha sido erigido sob a invocação de Santo Antonio, estava localizado "numa elevação do caminho existente onde hoje está a Rua Rebouças de Carvalho, entre as ruas posteriormente denominadas de São José (conhecida por beco do Pelourinho) e de São João (hoje Coronel Marcondes de Matos), próximo à atual capela de Santana." Foi responsável pelo Convento Velho o frei Antonio da Cruz e frei Jorge de Jesus Moreira. Segundo Gentil de Moura, ainda existiam ruínas deste convento na segunda metade do século XIX. Entendemos que muitos dos indígenas preados pelas armações de Taubaté foram divididos entre os religiosos que não ficaram por muito tempo na região.Gentil de Assis Moura, O capitão Jacques Félix Separata da Revista do Instituto Histórico e Geográfico do Estado de São Paulo, n.20, 1915. Ver também Félix Guisard Filho, Jacques Félix,1938,p.23. Ver também José Bernardo Ortiz, São Francisco das Chagas de Taubaté - Taubaté Colonial, livro 2º 1996,p33. 


\section{ICONOGRAFIA}

Nas duas versões da Carta 9a da Costa do Brasil (AHU 1141 e 1142)
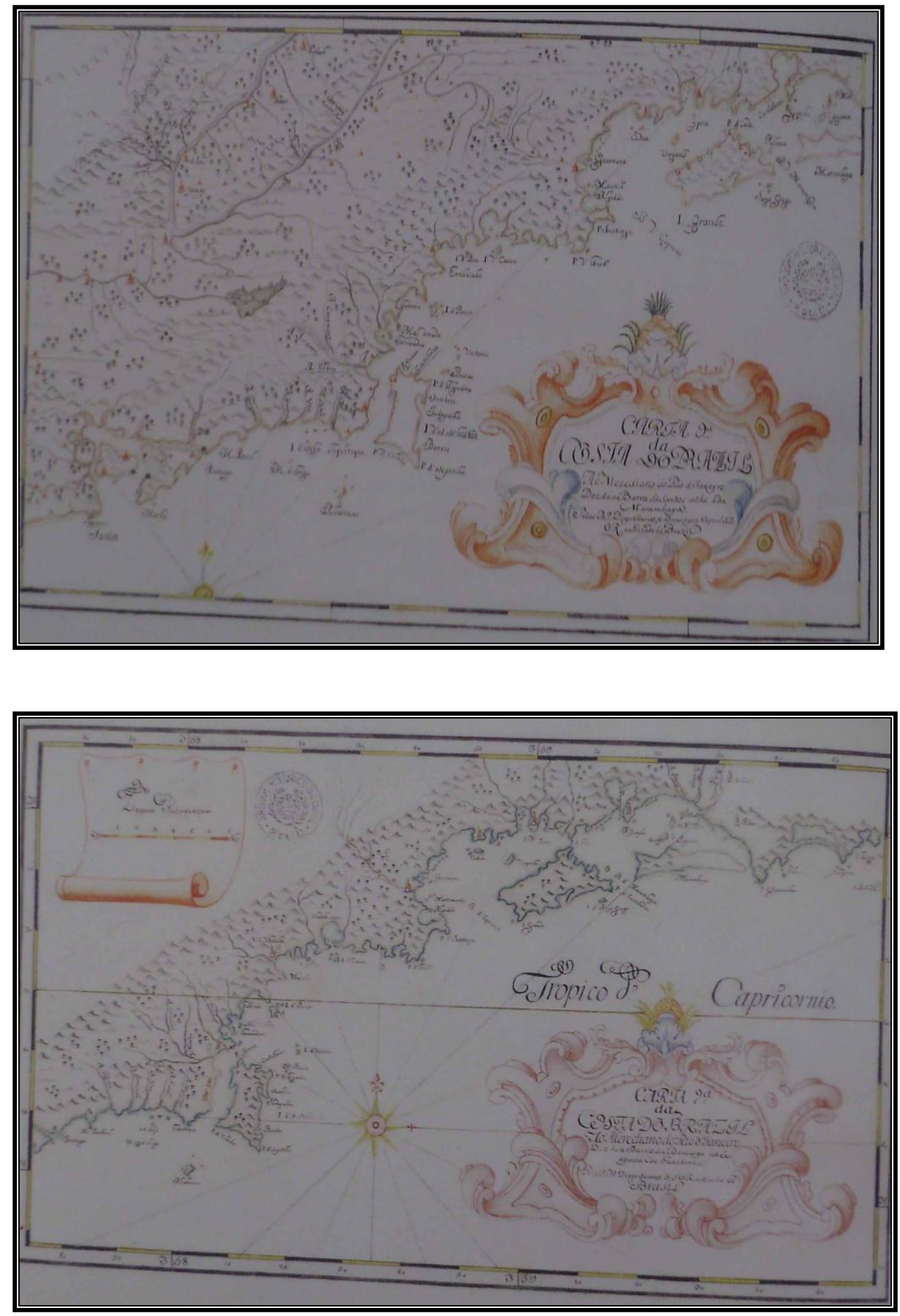
Fotografia Laura Castro Caldas e Paulo Cintra (Projeto Resgate) de autoria dos padres Diogo Soares e Domingos Capasci, encontram-se representados, no todo ou em parte, os trajetos dos caminhos: Caminho do Mar para São Paulo, Caminho Velho de São Paulo para as minas ou do Sertão e o Caminho Velho do Rio de Janeiro para as minas, de Paraty até Cunha, na subida da serra do Mar. A partir daí, o viajante passava pelas vilas paulistas, no Vale do Paraíba e entrava em Minas Gerais, atravessando a Garganta do Embaú, na serra da Mantiqueira.

FONTE: Os caminhos do ouro e a estrada real/Antonio Gilberto Costa (org.) Belo Horizonte: Editora UFMG; Lisboa: Kapa Editorial,2005, p.64

Caminho novo ou do Couto, aberto por Garcia Rodrigues, entre o Rio de Janeiro e Vila Rica.

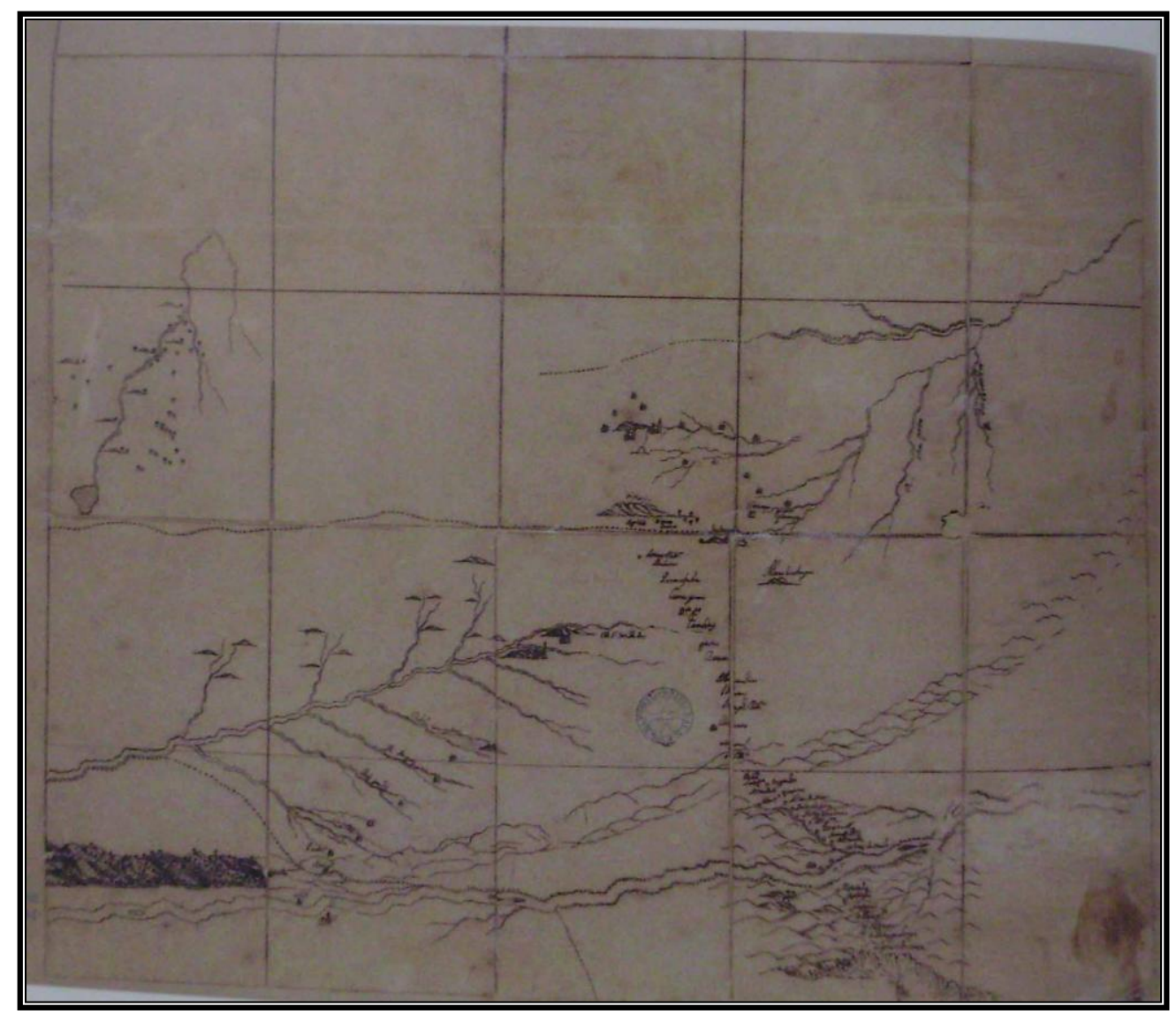

O documento com 52,5 x $64 \mathrm{~cm}$ e esboçado por bandeirante anônimo, traz o itinerário do Caminho Novo ou do Couto, aberto por Garcia Rodrigues, entre o Rio de Janeiro e Vila Rica. Encontram-se representados trechos das serras do Mar e Mantiqueira e as vilas de São João Del Rei e Vila Rica. Transposto o trecho representado da serra do Mar, aparecem os povoados de 
Inácio da Costa, Manga Larga, Alferes, Pão Grande e Rosinha. Atravessando o rio Paraíba do Sul, seguem os povoados de Simão Pereira,(...), José de Souza, Juiz de Fora, Alcaide-Mor, Moreira Queiroz,(...), Risioto, Gema,Caranday, Camapuan, Paraopeba, Mulatos,(...), Macabelo, Ouro Branco e a serra de Titiaya. Vila Rica e outros povoados vem representados mais a NORTE, assim como os rios que fazem parte da Bacia do Doce. O morro de Chagas, os povoados de Noruega, Piranga e Itaberaba, aparecem a OESTE.Lagoa Dourada [ traço a lápis] e São João Del Rei encontram-se representados a LESTE, assim como os rios das Mortes e Grande. A OESTE encontra-se parte da região das nascentes do rio São Francisco.

FONTE: Os caminhos do ouro e a estrada real/Antonio Gilberto Costa (org.) Belo Horizonte: Editora UFMG; Lisboa: Kapa Editorial,2005, p.58

Mapa das Minas Gerais com uma parte dos caminhos de São Paulo e do Rio de Janeiro para as minas e dos afluentes terminais do rio São Francisco.

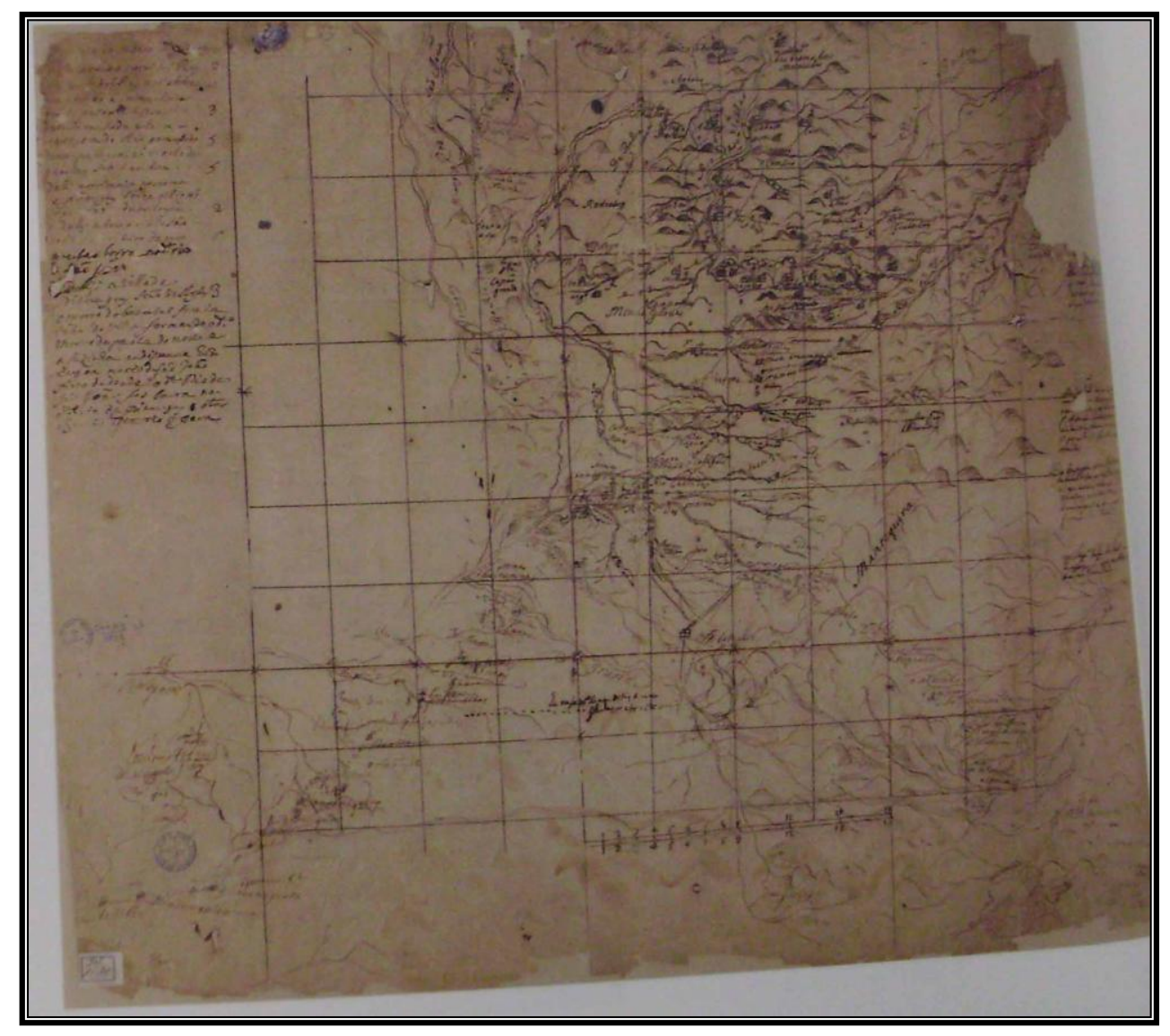

O documento cartográfico com 56 x $65,5 \mathrm{~cm}$ traz informações detalhadas sobre a região central de Minas Gerais e os traçados de vários caminhos, 
com destaque para Caminho dos Currais, Caminho pelo Sertão, Caminho de São Paulo para as minas e Caminho Novo, estes dois últimos respectivamente a partir de $\mathrm{SP}$ e RJ.

O Caminho de São Paulo está bem marcado entre Pindamonhangaba e Ouro Preto, passando por São João Del Rei e o traçado do Caminho Novo está bem definido entre o rio Paraíba e Ouro Preto. No mapa aparece a ligação entre os dois caminhos que passa por Barroso. As povoações de São João Del Rei, Ouro Preto, Sabará, Vila do Carmo, São Sebastião, São Caetano e outras encontram-se assinaladas no mapa. Esta carta não está incluída no conjunto das sertanistas por Cortesão (História do Brasil nos Velhos Mapas, t.II, p.227).

FONTE: Os caminhos do ouro e a estrada real/Antonio Gilberto Costa (org.) Belo Horizonte: Editora UFMG; Lisboa: Kapa Editorial,2005, p.58 


\section{CAPÍtULO 3}

\section{A TRANSFORMAÇÃO DOS SERTÕES DO VALE DO PARAÍBA}

É preciso, na história do Vale do Paraíba, considerar duas fases: exploração e conquista. Só assim se terá idéia de como se orientou e distribuiu o elemento humano nessa região, seu trânsito e instalação.

Provavelmente a primeira fase teria ocorrido entre 1580 a 1620 e a segunda fase entre 1620 a 1680, marcando a primeira às penetrações piratininganas dos séculos XVI e XVII, que mencionam a região do Vale e caracterizando à segunda pela concessão de terras para ocupação do território.

As expedições para o Brasil central seguiram dois itinerários: o rio Tietê e o rio Paraíba ou rio de Sorobis abundante em peixes ${ }^{1}$. Segundo Benedito Calixto, a exploração desta região deve ter sido antiga, uma vez que Martim Afonso de Sousa mandou uma "bandeira" para explorar a bacia do Vale do Paraíba, até as encostas da Mantiqueira (Sabarabuçu, na linguagem dos índios) $)^{2}$. Outros afirmam que a bandeira de Luís Grou,1587, foi uma das primeiras a percorrer a região dirigindo-se ao rio São Francisco. Também André de Leão e Nicolau Barreto devassaram a região , transpuseram a serra da Mantiqueira e demarcaram as nascentes do rio São Francisco. $^{3}$

As incursões e entradas paulistas fizeram com que se encontrassem definitivamente e com ciência perfeita do terreno, duas grandes diretrizes para a expansão paulista dos seiscentos : o centro mineiro via Vale do Paraíba e a região Paraná-Paraguaia. São essas regiões que serão os cenários onde os vicentinos abastecerão suas fazendas com mão-de-obra indígena, fixando vilas de abastecimento e favorecendo os caminhos para a região

\footnotetext{
1 Segundo Glimmer o rio Paraíba era conhecido em São Paulo de Piratininga como rio do Sorobis.RIHGSP, São Paulo, v.4,p.334 e Capistrano de Abreu, Capítulos de Historia Colonial, p.101

2 Benedito Calixto. Capitanias Paulistas, in: RIHGSP,1924,v.21, p.256. Segundo Orville Derby, a vinda de D.Francisco de Sousa à São Paulo favorecerá as expedições de exploração de minas em direção a Sabarabossú, "região mui rica em prata e da qual ele recebera noticia estando no governo da Bahia" e o incentivo do cativo indígena para a realização do projeto de colonização nas terras americanas. RIHGSP,v.5,p.93

3 Gilberto Martins. Taubaté nos seus primeiros tempos, 1973.
} 
mineira, ao mesmo tempo formando uma barreira militar de proteção assegurando as fronteiras internas das invasões de prováveis corsários europeus. O trânsito de exploradores, após a descoberta das minas de Sabarabuçu, tornará tão intenso que concorreu para o "despovoamento"da vila de São Paulo.

Ao estudarmos os caminhos das incursões paulistas nota-se que a região do Vale do Paraíba não será apenas uma passagem mas um objetivo. As "guerras justas" que ocorreram nessa região constituirão um elemento que fixará o conquistar europeu na intenção de "colonizar" as novas terras favorecendo o apresamento e extermínio de tribos inteiras.

\subsection{Os primeiros habitantes do Vale do Paraíba}

Desde o século XVI, cronistas, missionários, viajantes e historiadores compuseram o quadro etnográfico da Capitania de São Vicente e suas adjacências. Devido, entretanto, à confusão dos etnônimos, à notória mobilidade espacial dos grupos nativos [sobretudo no período da Colônia], às lacunas e incongruências nas informações registradas e a outros tantos empecilhos, as descrições e os estudos se encontram ainda hoje eivados de controvérsias, senão de contradições.

A reconstituição da Etno-história de nossas populações aborígines desde a chegada dos primeiros europeus é tarefa árdua, que requer muita paciência, longos anos de pesquisa e, sobretudo, atilado espírito crítico. Devido às lacunas de informação em livros e documentos [uns publicados, outros ainda enterrados em arquivos], não chegamos na maioria dos casos, à estabelecer com razoável segurança o processo decorrido desde os contatos iniciais entre os índios e os conquistadores europeus. Ninguém sabe com precisão de quantos grupos haviam no período da Colônia, a única memória que existe é apenas o nome tribal ou, talvez, um apelido qualquer dado por índios vizinhos ou invasores brancos. $\mathrm{O}$ pesquisador cauteloso, então, em vez de propor conclusões definitivas, estribado em tal ou qual autor de outros tempos, se há de contentar com hipóteses razoavelmente fundamentadas ou com sugestões que possam ajudar a compreender o que havia e o que se passou.

Por longo tempo, o fascínio pelo exótico ou "extravagante", que os observadores ou estudiosos deparavam nos sistemas de vida das tribos aborígines, os fez ignorar o que de interessante [em sentido histórico, sociológico, antropológico] marcou a trajetória do índio em seu convívio com o mundo dos brancos : muitas coisas deixaram de ser registradas, a não 
ser de esguelha, como simples referências marginais, mais ou menos rápidas, em relatórios, cartas ou documentos de outra natureza. ${ }^{4}$ [Importante frisar que a história oral entrelaçada a história do índio colaborou muito para o entendimento do encontro das culturas européias e indígenas e se torna até os dias de hoje, uma forte fonte de pesquisa para aqueles que buscam compreender o cotidiano das tribos, além dos vestígios deixados por estes nativos que favorecem aos estudos etno-históricos, arqueológicos e antropológicos mostrando novas abordagens de análise da convivência tribal]

$\mathrm{O}$ assunto discutido nesta parte do capítulo trabalha com relatos que procuram mostrar a possível localização dos Guaianás, Puris, Tamoios, Maromimis ou Jerominis da região do Vale do Paraíba Paulista. O clima, o relevo e a vegetação da região influenciaram na formação de aldeias que serviram muitas vezes de local de abastecimentos para os sertanistas de São Paulo que penetravam os sertões em direção da serra de Sabarabuçu. As rivalidades tribais, os ataques de incursões paulistas [as chamadas "guerras justas"], “os descimentos", também afetaram muito nas mudanças de aldeias de uma região para outra. Utilizaremos um mapa que foi criado a partir das viagens de Knivet quando enviado por Martim de Sá (1590) para buscar "selvagens chamados Pories [Puris] com quem os lusos haviam feito pazes há muitos anos". Os caminhos de Knivet auxiliou na provável localização das nações indígenas do Vale do Paraíba.

\section{Roteiro do primeiro caminho 1594 :}

Martim de Sá determinou que Knivet fosse comprar "Wianasses" na aldeia de Jaguarapipo, onde os indígenas "por facas e machados (...) vendiam mulher e filhos" [grifo nosso] aos portugueses. Mas, como esse aldeamento estava com população reduzida, [sem "peças" suficientes para vender], Martim de Sá ordenou ao ex-corsário anglo que “ ... fosse buscar um outro gênero de selvagens chamados Pories [Puris]...", com quem os lusos haviam feito pazes há muitos anos.

Depois de carregar oito escravos com mercadorias destinadas ao escambo [troca de indígenas por ferramentas e miçangas], a "missão comercial" principiou a sua jornada, em princípio de 1594, no aldeamento indígena existente na barra de Angra dos Reis, cruzou as serras do Mar e da Bocaina, desceu pelo vale do Rio Bananal, transpôs o Paraíba (rio Sorobis) e prosseguiu pelas terras ribeirinhas do Turvo em demanda das matas da margem direita do Rio Preto, até encontrar depois de uma viagem de "cem milhas", uma aldeia de Puris consideravelmente povoada, onde a caravana foi bem recebida por um "velho morubixaba" que tornou possível a

4 Egon Schaden, introdução do livro O indígena do Vale do Paraíba de Paulo Pereira dos Reis, 1979. 
negociação de setenta "escravos de todos sexos e idades" que, após uma jornada de regresso de quarenta dias, foram entregues à Martim de Sá. ${ }^{5}$

\section{Roteiro de Knivet (1594) descrito por Teodoro Sampaio :}

Partindo da aldeã guayanã de Jaguarapipo, situada provavelmente no valle do Ariró, no fundo da bahia de Angra dos Reis, e apartada do mar, a expedição, commandada pelo inglês, certamente tornou ahi a vereda que, transpondo a serra do Mar nas cabeceiras do rio Bananal, ia, a rumo de norte, mais directamente ao rio Parahyba; transpôs esse rio para a margem esquerda e, pelo Valle do Turvo, approximou-se da Mantiqueira, em terras que são hoje dos municípios de Valença e do Rio Preto, outrora habitadas dos poris. ${ }^{6}$

\section{Roteiro do segundo caminho 1597 :}

Em 14 de outubro de 1597, partiu do Rio de Janeiro, chefiada por Martim de Sá, uma expedição contra os Tamoios do Vale do Paraíba Paulista. Em seu itinerário, que se iniciou ao longo da costa, no sentido N-S, incorporaram-se à entrada "quinhentos selvagens [Wianasses] de (...) Jaguarapipo" e "oitenta frecheiros" " [Wianasses] da aldeia de Juqueriquerê, na costa fronteira à ilha de São Sebastião", somando ao todo setecentos portugueses e dois mil índios que desembarcaram em Paraty, donde prosseguiram, pelo litoral , “... até perto de Ubatuba" atravessaram a serra do Mar para percorrerem, durante "...quarenta dias (...) vales e montes", até atingirem um "...grande rio chamado Paracuona", que foi transposto, com dificuldade, navegando-se em jangadas, numa operação que durou quatro dias, devido ao vento e correnteza que "eram mui fortes"

Depois de atravessar esse rio [Paracuona], Knivet e seus companheiros prosseguiram por " uma vereda que os teria levado até as proximidades da actual villa de Jambeiro" ${ }^{11}$, donde atingiram "... um grande monte..." Sampaio reconheceu como sendo a serra de Itapeva [prolongamento do Quebra Cangalhas, à Nordeste] ${ }^{13}$. Transposto este [monte], chegamos a uma região de um solo baixo e humido, onde se achavam muitos cannibaes chamados Pories." 14

5 Paulo Pereira dos Reis, O indígena do Vale do Paraíba, p.92

6 Teodoro Fernandes Sampaio, Peregrinações de Antonio Knivet no Brasil do século XVI, tomo especial, parte II, Imprensa Nacional, Rio de Janeiro, 1915.p.368.

7 Anthony Knivet, RIHGB, tomo XLI, Rio de Janeiro, Tipografia Pinheiro e Cia, 1878, p.225-226.

8 Teodoro Sampaio, Peregrinações de Antonio Knivet no Brasil do século XVI, p.372.

9 Anthony Knivet, RIHGB, tomo XLI,1878, p. 227. Teodoro Sampaio identificou esse rio como sendo o Paraibuna, esclarece ainda que a grafia está errada, porque Knivet escreveu “...Paraeyna para designar o Parahyba, possivelmente que Paracuona seja um modo errado de escrever Paraeuona ou Paraeyona, que na pronunciação inglesa dá Paraiyúna, equivalente ao nosso Parahybuna.Teodoro Sampaio,op.cit., p.372

10 Ibidem,p.227

11 Teodoro Sampaio,op.cit.,p.373.

12 Knivet, op.cit., p.227.

13 Teodoro Sampaio,op.cit., p.373

14 Knivet, op.cit., p.228. 
A "bandeira", continuando a sua marcha, depois de quatro dias de jornada, alcançou o rio Paraíba, em cujas margens depararam com "....alguns cem Pories entre homens e mulheres" "15 num sítio que Sampaio supôs pertencer ao "actual districto de São José dos Campos. ${ }^{16}$

Os Puris apontaram "um lugar a dois dias de viagem d'ahi...", onde os portugueses encontrariam "....favas ou ervilhas, milho e raízes...."17, não esclarecendo o relato se tratava-se de um aldeamento dos próprios Puris ou de seus amigos Guaianás.

Os expedicionários cruzaram o rio e, após sete dias, adentraram na aldeia indicada à procura de provisões, deparando somente com mulheres, porque os homens que haviam "...sahido a guerrear com os Tamoyos foram todos mortos". ${ }^{18}$

De acordo com a narrativa de Knivet, a sua primeira viagem mostra que durante o século XVI, já havia um comércio de escravos indígenas entre os portugueses e os caciques das tribos. Neste roteiro ele enfatiza os Puri do Vale do Paraíba que já conheciam as transações de escambo e recebiam os lusos como aliados. No segundo roteiro Knivet relata uma expedição chefiada por Martim de Sá cujo objetivo era atacar os Tamoios do Vale do Paraíba Paulista, encontra aldeias Puris que os abriga e durante a estadia na aldeia os indígenas mostram o caminho onde encontrariam provisões para sua expedição, próximo de uma aldeia provavelmente dos Maromimis [também conhecidos por Guaianás].

GUAIANÁS: A palavra guaianã é tupi, mas não é nome de nação, sendo empregada pelos tupis para designar "gente aparentada", "aquele que é parente". Os Carijós chamavam ao gentio de São Vicente "Guayanã" ou "Tupinakim". 19

TAMOIO: Como explicou Varnhagen em seus Comentários no Tratado Descritivo do Brasil em 1587, a palavra Tamoio quer dizer, avô, ascendente, antepassado. ${ }^{20}$

TEMIMINOS (OU DO GATO): Esses indígenas habitavam a baia da Guanabara, mas hostilizados pelos Tamoios que lhes moviam perseguição implacável, emigraram para o Espírito Santo, em 1555, onde foram aldeados

15 Ibidem,p.228

16 Teodoro Sampaio, op.cit.,p.373. Mas se bem observarmos esta região possivelmente era Lorena e não São José dos Campos como Sampaio descreve.

17 Knivet,op.cit.p. 228

18 Ibidem,p. 229.

19 Teodoro Sampio,A propósito dos Guayanazes, p.201

20 F.A. Varnhagen, nota n.39. In: Gabriel S. Sousa, Tratado Descritivo, p.359 
pelos jesuítas, conforme carta do Pe Brás Lourenço, de 10 de junho de $1562 .^{21}$

PURIS - Jorge B.Stella dividiu os Jês em quatro grupos: orientais, setentrionais, centrais e meridionais. Enquadrou entre os Jês orientais: "os Coroados e os Puris, que vivem desde o rio Parahyba até o Espírito Santo, penetrando na parte oriental de Minas Geraes. Os Goyatakás, entre o baixo Parahyba e o Macahe ${ }^{22}$ Robert H. Lowie acrescenta que o "grupo PuriCoroado entre os Jês considerados como brasileiros orientais." ${ }^{23}$ Com relação ao grupo Goyatakás , Simão de Vasconcelos não concorda em indentificá-los como descendentes dos Puris, informou que eles moravam em palafitas e os dividiu em três grupos Goitacá-Mopi, Goitacá-Jacoritó e Goitacá-Guaçu. ${ }^{24}$ Metraux aceita esta classificação, esclarecendo que os Guaitacá-guassu eram hostis aos outros e perambulavam pelo interior. ${ }^{25}$

COROADOS - No Rio de Janeiro o nome de Coroados foi generalizado a todos os selvagens que se distinguiam pela maneira de cortarem o cabelo, ou fosse em torno e no alto da cabeça, como os Goitacazes, ou só no alto da cabeça ficando os cabelos longos e corridos, espargidos pelos hombros, como os Araris, Xumetós e Pitás. ${ }^{26}$

MAROMOMIS - ou Maromimis ou Miramumis ou Guaramumins por serem pequenos e barrigudos foram chamados de Guarus (barrigudos) ou Guarulhos. Habitavam o sertão da Capitania de São Vicente. ${ }^{27}$

21 Carta do Pe. Brás Lourenço (Espírito Santo, 10/jun/1562),vol. III,p.467. Conforme o padre parte dos Temiminós retornou ao Rio de Janeiro, após a expulsão dos franceses da baía da Guanabara, instalado-se às margens do Rio Muriaí e entre o Rio Macacu e a Serra dos Órgãos, onde receberam uma sesmaria em 1579.

22 Jorge Bertolaso Stella. As línguas indígenas da América, separata da RIHGSP,vol.26,1928

23 Robert H. Lowie. The Tapuya. In: Handbook of South American Indians,Smithsonian Institution,vol.1, Washington, United States, 1946

24 Simão de Vasconcelos. Vida do Padre João de Almeida,cap.XII,148.Lisboa,Editora A.J.Fernandes Lopes, 1658.

25 Alfred Metraux. The Guaitacá, In: Handbook of South American Indians,Smithsonian Institution,vol.1, Washington, United States, 1946,p.521/522

26 Joaquim Norberto de Sousa Silva. Memória Histórica e Documentada das Aldeias de índios da Província do Rio de Janeiro. In: RIHGB, tomo XVII, Rio de Janeiro, Imprensa Nacional,1894,p.88

27 Teodoro Sampaio registrou Miramomis. O tupi na geografia nacional.In: RIHGSP,vol.II,1896-1897. Ver também Serafim Leite. Os Jesuítas e os índios Maromomis na Capitania de São Vicente.In:RIHGSP.vol.XXXII,São Paulo,Editora do Instituto e Geográfico de São Paulo,1937 
Provável localização das nações indígenas do Vale do Paraíba segundo Knivet final do século xvi

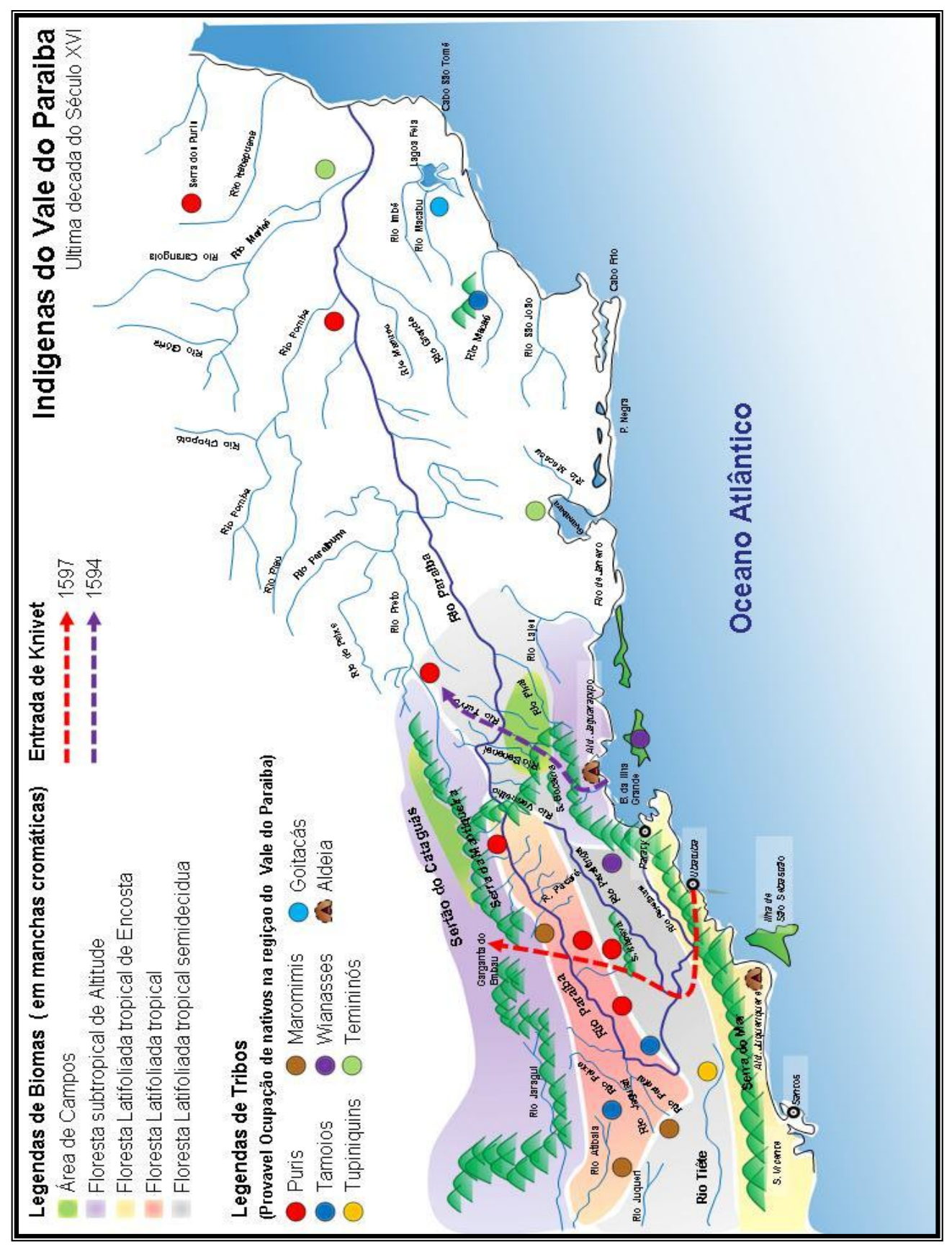

\subsection{A Vila de São Francisco das Chagas de Taubaté}

D. Mariana de Sousa da Guerra, Condessa de Vimieiro, neta de Martim Afonso de Sousa e mulher de D. Francisco de Faro, Conde de Vimieiro, tornou-se em 1611, herdeira e quarta donatária da "capitania das cem léguas da vila de São Vicente", tendo a doação que recebera de Lopo 
de Sousa $^{28}$ sido confirmada pelo rei D.Filipe somente em 22 de outubro de 1621 , tomou posse da capitania em 1623, por intermédio de seu procurador João de Moura Fogaça.

Quando, em 1624, o Conde de Monsanto, D. Álvaro Pires de Castro e Sousa repeliu a Condessa de Vimieiro das vilas de São Vicente, Santos, São Paulo e Mogi das Cruzes, a Vila de Nossa Senhora da Conceição de Itanhaém passou a ser a "cabeça da capitania".

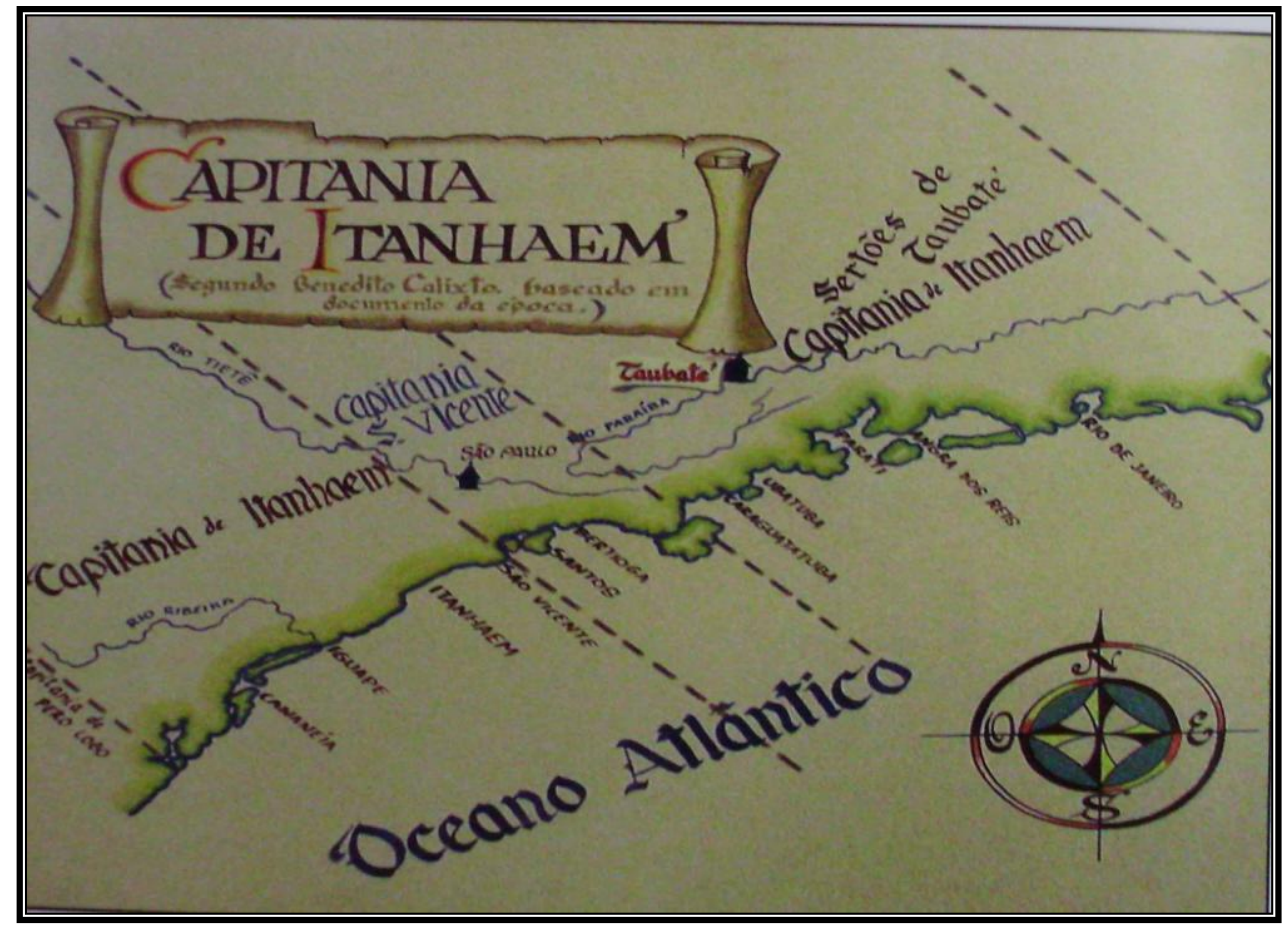

Desenho feito pelo Prof. Paulo Camilher Florençano, ilustrando a provável localização da Capitania de Itanhaém. Acervo DMPAH

Várias disputas entre os Vimieiro e os Monsanto aconteceram por posses de terras na região onde está localizada a Capitania de Itanhaém.Mas após longo letígio, foi dado causa ganha à D.Mariana de Sousa da Guerra, Condessa de Vimieiro. ${ }^{29}$

28 Lopo de Sousa, neto de Martim Afonso de Sousa,faleceu na África combatendo os mouros, deixou um filho bastardo, o qual, por escritura passada em Lisboa, em 07 de março de 1611 , cedeu todos os seus direitos sobre a capitania de São Vicente a D. Mariana de Sousa Guerra, Condessa de Vimieiro.In:Pedro Taques A. P. Leme, História da Capitania de São Vicente, p.74-75.

29 Ver Consulta do Conselho Ultramarino ao príncipe regente D.Pedro sobre o requerimento do conde da Ilha do Príncipe e descendente de Martim Afonso de Sousa. Conforme Arquivo Histórico Ultramarino, a partir dos catálogos do Projeto Resgate "Barão 
Jacques Félix ${ }^{30}$, o moço, morador da vila de São Paulo, e seus filhos Domingos Dias Félix e Belchior Félix, requereram à João de Moura Fogaça, Capitão-mor da Capitania de Itanhaém, a concessão de terras na região do Vale do Paraíba.O citado governador da Capitania, na qualidade de procurador-geral da Condessa de Vimieiro, deferiu o requerimento, expedindo, em Angra dos Reis, em 21 de novembro de 1628, a Carta de data pela qual foram concedidas a cada um deles sesmarias de meia légua de terras entre Pindamonhangaba e Tremembé, às margens do rio Paraíba, próximo a "tapera do gentio". ${ }^{31}$ Jacques Félix, ainda permaneceu em São Paulo, onde foi vereador em $1632^{32}$, nesse mesmo período chefiou uma expedição que reduziu os índios Uerominis e Puris do Vale do Paraíba. Em 1636, foi provedor da Santa Casa de São Paulo. ${ }^{33}$

Em 20 de janeiro de 1636, Francisco da Rocha, quarto-governador e ouvidor da Capitania de Itanhaém, "passou provisão a Jacques Félix, opulento morador da Vila de São Paulo, autorizando-o a penetrar no sertão de Taubaté, a fim de descobrir minas e conquistar terras em nome da Condessa de Vimieiro, cujos domínios no sertão eram ainda desconhecidos. ${ }^{34}$

Jacques Félix, o moço, conquistou o sertão de Taba-etê, fundou um arraial onde se fixou com sua família, agregados, índios escravos e animais domésticos que trouxera.

Conforme Francisco de Paula Toledo, Taubaté foi originalmente a aldeia de Itaboaté, onde viviam muitas famílias de índios Guaianazes, os quais no princípio do século XVI se tornaram inimigos declarados dos

do Rio Branco" no que se refere à Capitania de SãoPaulo. AHU_ACL_CU_023,cx.1,D.12; AHU_ACL_CU_023,cx.1,D.13; AHU_ACL_CU_023-01,cx.1,D.24

30 Jacques Félix, o moço, nasceu por volta de 1570, é homônimo de seu pai Jaques Félix, flamengo, nascido por volta de 1540, que veio para São Vicente e casou-se nessa vila cerca de 1569 com uma filha de povoadores da Capitania. Foi pai de : Capitão-mor Jaques Félix, fundador oficial de Taubaté, casado com Francisca Gordilho; Ascensa Félix casada com Lourenço Nunes; Isabel Félix casada com Diogo Sanches, espanhol, morador em São Paulo . O capitão Domingos Dias Félix, filho de Jaques Félix, o moço, teve três filhos : Capitão Jaques Félix (Neto), homônimo de seu avô e bisavô, nascido cerca de 1635 casado com Páscoa Lobo de Oliveira, foi morador em seu sítio de Tremembé; Catarina de Góis, nascida em 1640, casada com Alberto Lobo de Louzada; Inês Dias Félix, nascida cerca de 1645, casada com Manuel Gil de Siqueira que foi juiz ordinário em 1665,1670 e 1695.In: Revista da ASBRAP n.12, 2006,p.83-89.Ver site www.asbrap.org.br.

31 Ver Sesmaria divulgada por Benedito Calixto em Capitania de Itanhaém, RIHGSP,1915,p.559-560 e Felix Guisar Filho, Jacques Félix, p.15-16

32 Conforme Ata da Câmara da Vila de São Paulo de 01 de maio de 1632. In: ACSP 16291639, vol.IV,p.118

33 Ver Américo de Moura, Os Povoadores do Campo de Piratininga, RIHGSP, vol.XLVII, s/d(prefácio de setembro de 1950),p.355.

34 Benedito Calixto, Capitania de Itanhaém,op.cit.,p.430 
índios da mesma raça que habitavam os campos de Piratininga,quando a vila de Santo André foi mandada arrasar. ${ }^{35}$ Benedito Calixto afirmou que Jacques Félix fundou o arraial de Taubaté sobre os escombros de uma antiga aldeia de Guayanazes por ele reduzidos. ${ }^{36}$

(...) os que eram pelos herdeiros de Piqueroby contra o estabelecimento dos europeus Em serra acima e contra a chefia suprema de Tibiriçá retiraram-se para o interior (...) Indo o grupo maior estabelecer-se nas margens do Parahyba onde fundaram Tab-a-été, taba legítima, em oposição a taba de Piratininga (...) em poder dos Guayanas que se tinham 'deixado escravizar' pelos conquistadores. ${ }^{37}$

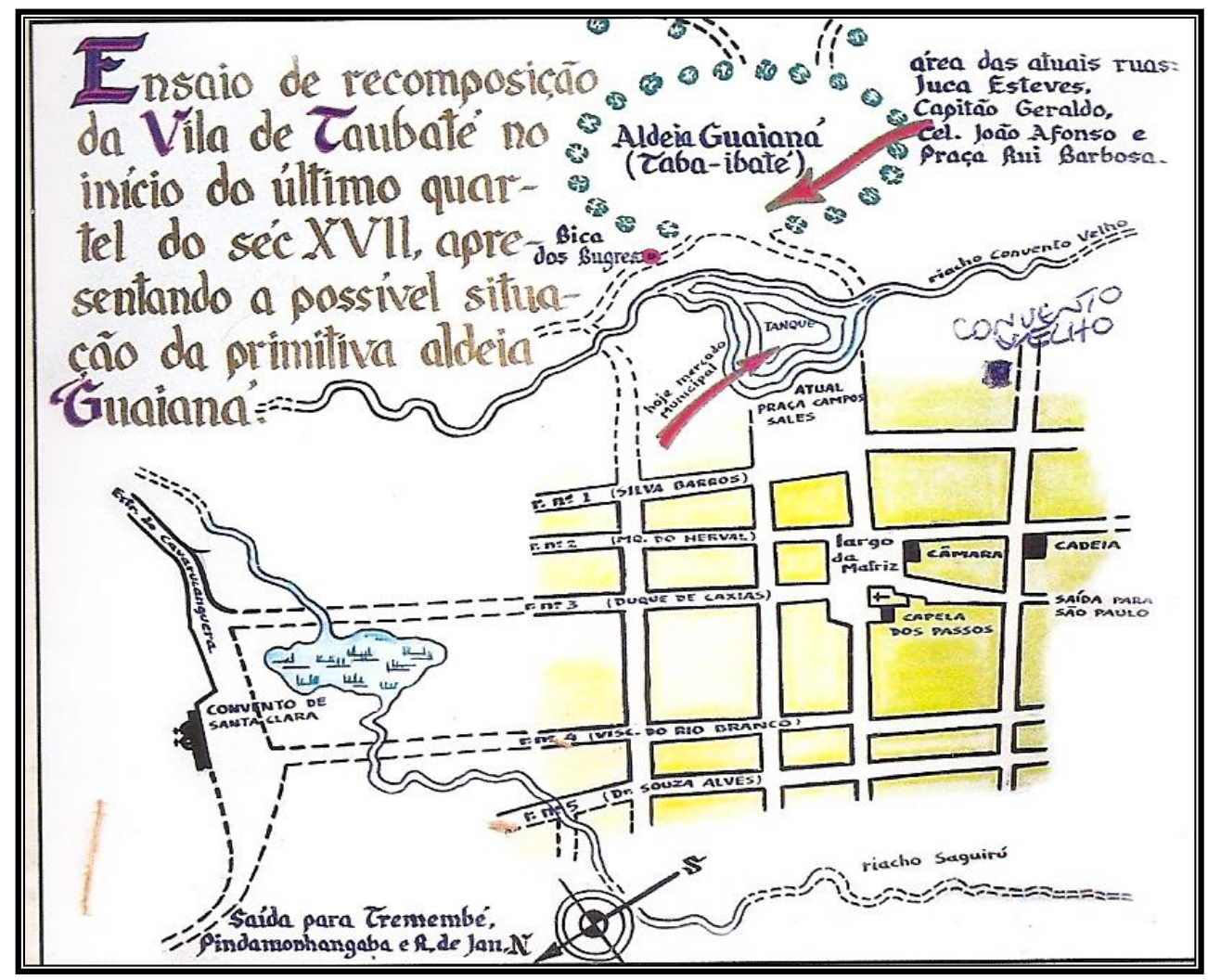

\section{Situação da primitiva aldeia Guainá. Acervo DMPAH}

De fato segundo a historiadora Prof. ${ }^{a}$ Maria Morgado de Abreu e o

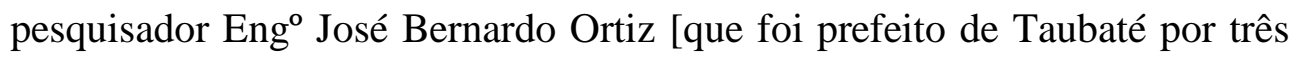
mandatos], durante algumas obras realizadas no mercado municipal e próximas ao atual Cristo Redentor, parte alta da cidade de Taubaté, foi encontrado alguns utensílios que provavelmente pertenceu a antiga aldeia Guaianá que viveu neste local no período da Taubaté Colonial. O aldeamento ocupava a região onde ficam, parcialmente, as ruas Capitão

35 Francisco de Paula Toledo,História do Município de Taubaté,p.11

36 Benedito Calixto, op.cit.p.552-553

37Afonso A. de Freitas. Os Guaianás de Piratininga,RIGHSP, vol.XIII, p.368. 
Geraldo, Coronel João Afonso, Travessa São José e Praça Rui Barbosa (largo do Chafariz), mas o local de sepultamento se estendia até depois da atual rodovia Presidente Dutra, o que se pode depreender das ossadas e peças indígenas lá encontradas. ${ }^{38}$

Por provimento de 13 de outubro de 1639, Vasco da Mota, governador de Itanhaém, ordenou que Jacques Félix, "capitão-mor povoador", logo que completasse as obras necessárias "para se aclamar em vila e povoação", fizesse o aviso à governadoria. Em 5 de dezembro de 1645[data em que se comemora o aniversário da cidade], Antonio Barbosa de Aguiar, Capitãomor, ouvidor e alcaide-mor de Itanhaém, em nome da Condessa de Vimieiro, elevou à categoria de vila o povoado de Taubaté, instalando-se, solenemente, a Câmara no dia 1 de janeiro de $1646 .{ }^{39}$ Neste mesmo ano, Duarte Correa Vasques Annes, como administrador das minas, encarregou Jacques Félix, através de provisão datada no Rio de Janeiro, de penetrar o sertão de Guaratinguetá, com o intento de descobrir minas. O sertanista capitão Jacques Félix, assim o fez, transpondo a serra da Mantiqueira, pela garganta do Embaú até o rio Verde, invadiu as terras dos índios Cataguás. ${ }^{40}$ Estes resolveram se concentrar nas matas a oeste do Rio Grande, e recuaram o seu domínio para os países do Piumbi e do Tamanduá, de onde cessaram mesmo as suas correrias, logo que Lourenço Castanho os foi debelar e pôr em debandada. Com os caminhos livres para a entrada do sertão, começaram os aventureiros a subir até o rio das Velhas e cabeceiras do rio Doce. Postos em caminho, a marcha nenhuma dificuldade ofereceu até Guaratinguetá, região aberta e freqüentada, havia anos. ${ }^{41}$ Outra característica do capitão Jacques Félix, era que suas fazendas abasteciam as comitivas que iam em direção a região mineradora, como aconteceu com a comitiva de D. Rodrigo Castelo Branco, que subindo com toda sua gente para as minas, contava com as plantações das fazendas do dito capitão.

38 José Bernardo Ortiz,São Francisco das Chagas de Taubaté, Livro 2º, p.13-14. Ver também Maria Morgado de Abreu, Taubaté através de textos,p.39. Com relação ao vocábulo Taubaté provém de étimos tupis que pode ser derivado de duas hipóteses: a) Taba (aldeia) e eté (verdadeira): aldeia verdadeira;b)Taba (aldeia) e ibaté (alta) : Tabaibaté,Tabebaté e Tabibaté, com a significação de aldeia alta.In: José Bernardo Ortiz,op.cit.,p.12-13.

39 Pedro Taques de A.P. Leme, História da Capitania de São Vicente,p.150-152 e Benedito Calixto, Capitania de Itanhaém, p.546.

40 Frei Gaspar da Madre de Deus,Memórias para a história da capitania de São Vicente,p.555

41 Felix Guisard Filho, Jacques Félix,p.18-20. 
Não menos para animar essa bandeira, correu a certeza de estarem os caminhos limpos de inimigos, desde que Lourenço Castanho fez recuar os Cataguás para o centro. Esses Bárbaros, ainda mesmo depois da entrada de Jacques Félix e de Fernão Dias, não deixaram de fazer o corso nas regiões do rio Grande; Lourenço Castanho, porém, tendo encontrado uma horda, exterminou-a no lugar que, por isso, recebeu o nome de Conquista. ${ }^{42}$

Ao que tudo indica o capitão Jacques Félix facilitou as entradas em direção ao sertão dos Cataguás, [região mineradora], abastecendo as comitivas com alimentos e terreno limpo de selvagens, a consequiência deste trabalho está no numeroso grupo de famílias procedentes de São Paulo, a pedir datas de sesmarias em derredor das fazendas do dito capitão. Não só de São Paulo, mas também outras famílias vindas do Rio de Janeiro se fixaram na região do Vale do Paraíba, muitas esperançosas pelas minas de metais preciosos e outras pela busca de cativos indígenas para seus sítios e fazendas. São elas :

Os capitães João do Prado Monteiro,Manuel da Costa Cabral,Sebastião Gil e seus filhos,Pedro Pascoal,Sebastião Amaro,Antonio Manuel Bento e seu genro Antonio Delgado Escobar, Miguel Luiz, Braz Gonçalves, José de Faria, o padre Miguel Veloso, Manuel Coelho de Souza, João Veloso, Antonio Rodrigues, João de Azevedo Coutinho, Antonio Bicudo Leme, Fernão Leme e Braz Esteves Leme, Cristóvão Rodrigues de La Penha, D. Bernardo de Sanches de La Pimenta, Domingos Lins Pelladam,Antonio Raposo Barreto, Antonio Gonçalves, coronel Antonio de Faria Albernaz, Luiz Fernandes, Domingos Dias, João Correia, Antonio de Barros Freire, Dionísio,Gabriel e Miguel de Góis, Manuel Martins Bezerra, Francisco Farel,Domingos Pires Valadão, Sebastião Luiz, Francisco Botelho, João Delgado de Escobar, Manuel de Oliveira Sarmento, Antonio Teixeira Side, capitão Antonio Vieira da Maia e seus filhos João Vieira da Maia, Henrique e Mateus Vieira da Cunha, Manuel Correia de Andrade, Antonio Tenedo, frei Antonio da Cruz, Rodrigo Gomes, Estevão da Cunha e seu filho Henrique da Cunha Lobo, Antonio Furtado, Batista Gago, Henrique Nunes, Manuel e Miguel Fernandes Edras, Francisco da Cunha de Oliveira, padre Pedro Ribeiro do Vale, João Martins, Estevão Raposo Barbosa, Bartolomeu e Antonio da Cunha Gago, Tomé Portes d'el Rei, Pero de Pontes, Manuel de Oliveira Falcão, Domingos Luiz Leme, Francisco Ribeiro Banhos, Domingos Velho Cabral, Mateus Vaz Porto Alegre, Rafael de Sousa Castelo Branco, D.Pedro Fernandes Aragones, Jerônimo Galante, João Ribeiro de Lara, Peres de Lima, Antonio Monteiro de Alvarenga, 
Sebastião Monteiro Pereira, Domingos Alvares Pereira, Domingos Luiz Bicudo,etc.. ${ }^{43}$

Toda essa leva de famílias foram pesquisadas nos testamentos e inventários relacionados no anexo 1 desta pesquisa, a qual obtendo datas de terras e sesmarias fundaram as cidades que hoje pertencem a região do Vale do Paraíba Paulista e outras cidades em direção ao sul de Minas Gerais, Mato Grosso e Goiás.

\subsection{O Convento de Santa Clara : converter os "gentios da terra" e fortalecer a fé dos colonos taubateanos}

Durante muito tempo (há mais de 10 anos) às lacunas relacionadas ao relacionamento dos religiosos franciscanos e cativos indígenas do período seiscentista, foram de dificílimo acesso. Pouquíssimas fontes sobre a história do Convento de Santa Clara do período colonial foram encontradas. No próprio convento alegava-se a um incêndio ocorrido em 1842, a causa da perda destas fontes; outro fator que favoreceu a dificuldade em conhecer melhor a história deste convento, foi alegarem que a biblioteca do atual convento estava muito desfalcada, não havia muita coisa que pudesse auxiliar nas pesquisas. Mas graças ao frei Róger Brunorio,OFM, do Convento de Santo Antonio, da Arquidiocese de São Sebastião do Rio de Janeiro, pudemos colaborar de forma simplória e preencher a lacuna que faltava neste imenso "quebra-cabeças" que ainda está por ser montado. Assim trabalharemos principalmente com os estudos minuciosos realizados pelo frei Basílio Rower,OFM, grande estudioso da História Franciscana no Brasil. De seus estudos recortamos sobre a região de Taubaté no século XVII. $^{44}$

Sempre nos perguntamos por que na região de Taubaté, os jesuítas não implantaram seu sistema de reduções? Por que nas comitivas dos colonos paulistas em direção ao sertão não participaram religiosos jesuítas? Como já mencionamos em capítulo anterior, os conflitos entre esta ordem religiosa e os colonos paulistas foram de longa duração, suas contendas girava em torno do trabalho indígena. Não que o a mão-de-obra africana não participasse de seus conventos e fazendas, pelo contrário. Ocorre ainda que nos finais do século XVII, a Companhia de Jesus já possuía no Brasil uma

43 Félix Guisard Filho, Jacques Félix,p.23-24.

44 Estudos que encontramos sobre o Convento de Santa Clara foram realizados a partir do século XIX, anterior a estes só encontramos algumas anotações feitas por Félix Guisard Filho, Maria Morgado e Bernardo Ortiz, todos pesquisadores de Taubaté. 
vasta rede de unidades produtivas, baseadas no trabalho de escravos negros, com as quais financiavam seus estabelecimentos de ensino e atividades de catequese. [Mas por que o índio?] Administrando com habilidade as aptidões da mão-de-obra indígena para a coleta das drogas na floresta, privilegiados pela isenção do pagamento do dízimo eclesiástico e de direitos alfandegários, as reduções jesuíticas conheceram notável prosperidade. O que prevaleceu, foi o interesse comercial, não importando que os padres missionários fossem pessoalmente desprendidos e empregassem o excedente econômico apropriado na própria obra religiosa. ${ }^{45}$

Através do Regimento das Missões, de 21 de dezembro de 1686, não foram dadas exclusividade aos jesuítas em aldear indígenas, este permitiu a organização de aldeias por outras ordens religiosas. Gilberto Freyre é de opinião que os índios ganhariam muito mais com o sistema pedagógico franciscano do que com o jesuítico. ${ }^{46}$ Mas a realidade das aldeias dos capuchinhos de São Paulo, ficou muito distante dos princípios de São Francisco de Assis, os índios estavam obrigados a entregar aos frades metade dos jornais que ganhassem e se submetiam a um Regulamento superlativo na enumeração da faltas insignificantes e capciosas às quais correspondia a pena universal dos açoites. ${ }^{47}$

Como aconteceu a origem do Convento de Santa Clara? De acordo com frei Gaspar da Madre de Deus, estes capuchos eram da Província de Santo Antonio de Portugal.

No $1^{\circ}$ de janeiro de 1558 , saíram de Lisboa o padre Fr. Melchior de Santa Catarina, Custodio, Comissário Geral, e mais sete religiosos da dita Província, os quais todos chegaram a Pernambuco em 12 de abril, onde edificaram o seu primeiro convento, depois outros muitos em várias partes. Estes conventos se formou uma Custodia, que 62 anos esteve sujeita a Província de Portugal. No ano de 1649, se eximiu desta sujeição, ficando

45 Jacob Gorender. Formas incompletas de escravidão indígena: reduções jesuítas,op.cit.,p.506. E ainda refletindo sobre esta questão citando J. Lúcio de Azevedo "que apesar dos cânones da Igreja e das leis da própria Companhia de Jesus proibirem os negócios temporais, os jesuítas no Novo Mundo, eram colonizadores: (...) a obra, que haviam empreendido, tinha caráter temporal, e, nessa qualidade, somente com os meios temporais se poderia realizar. A sociedade religiosa era também mercantil. Tinha nos centros de catequese, feitorias; nos missionários, caixeiros, regentes agrícolas ou diretores industriais; e todo o sistema se movia a mando do gerente, que era o procurador da província de Lisboa, efetuando as transações finais, recebendo o produto das vendas, presidindo as operações de contabilidade.” In: J. Lúcio de Azevedo, Os jesuítas no GrãoPará, Lisboa, Liv. Editora Tavares Cardoso \&Irmão,1901. Ver também C.R. Boxer, A idade do ouro no Brasil, op.cit., capitulo XI.

46 Gilberto Freyre. Casa-Grande \& Senzala. T. I,p.200-203

47 José Arouche de Toledo Rendon, Memória sobre as aldeias dos índios da Província de São Paulo, RIHGB,t.IV, 1863. Ver também recente trabalho publicado de frei Basílio Rower, No Capitulo III : 1677 a 1700 : Os escravos do convento.O Convento de Santo Antônio do Rio de Janeiro, 2008 
subordinada unicamente ao Ministro Geral dos Observantes, mas retendo a primitiva qualidade de Custodia até 5 de novembro de 1659, em que passou a graduação mais alta, sublimada ao predicamento de Província, em virtude de um breve do Santíssimo Padre Alexandre VII, de 24 de agosto de 1659. O seu nome era Província de Santo Antonio do Brasil, e estendia-se por todo ele desde a Paraíba do Norte até São Paulo. Depois, dividiu-se em duas : a primeira ficou conservando o nome antigo, e a sua cabeça é o Convento da Bahia; a segunda tomou o nome de Nossa Senhora da Conceição do Rio de $\underline{\text { Janeiro }}$ [grifo nosso], por ser o convento desta cidade a sua casa capitular. Os conventos desta última Província foram: o da vila de Vitória, fundado em 1591, o de Nossa Senhora da Penha, o de Cabo Frio, o do Rio de Janeiro, em 1606, o de Cacerubu ou Macacu, em 1649, o da Ilha, no recôncavo do Rio de Janeiro, o da Ilha Grande, em 1650, o da Ilha de São Sebastião, em 1659, o de Itanhaém, em 1655, o de São Paulo, em 1639, o de Itú e de Taubaté $\left[1674\right.$, grifo nosso]. ${ }^{48}$

Após a aprovação da Condessa de Vimieiro dada à Jacques Félix em explorar os sertões de Taubaté, junto com sua família, e índios de sua administração, veio religiosos carmelitas e franciscanos. Todos ajudaram na construção de uma pequena capela para servir de matriz, a capela dos Passos, fez-se uma casa para Conselho e cadeia.

Estando acabadas as obras para a povoação ser elevada à vila, foram feitas provisões para as eleições de juízes ordinários e oficiais da Câmara, que todos passaram a servir a partir de $1^{\circ}$ de janeiro de 1646. Para padroeiro da vila e da paróquia foi escolhido São Francisco das Chagas, escolha que demonstra as relações de amizade que o capitão Jacques Félix mantinha em São Paulo com os franciscanos, que temporariamente estiveram na vila em sua companhia.

E o convento velho de Santo Antonio, existiu? Alguns historiadores da região do Vale do Paraíba não chegaram a nenhuma conclusão a respeito, o que se chegou a contento foi que esta nomenclatura de "convento velho" foi dada após a construção do novo convento de Santa Clara. ${ }^{49}$ Frei Basílio alega que possívelmente se tratava de uma pequena Residência ou Hospício dos Religiosos de Nossa Senhora do Carmo, residentes em Mogi das Cruzes desde 1627. Hospício que impropriamente chamavam Convento, como acontece ainda hoje em tais casos. Os Carmelitas abandonaram-no aos poucos, depois que os Franciscanos se estabeleceram na vila. No arquivo antigo da Província de Nossa Senhora da Conceição do Rio de Janeiro nada foi encontrado a este respeito. ${ }^{50}$ Entendemos que os Carmelitas estiveram na expedição de Jacques Félix para prear índios do sertão, assim que

48 Frei Gaspar da Madre de Deus, Memórias para a História da Capitania de São Vicente,op.cit.p.242-243

49 Felix Guisar Filho, O Convento de Santa Clara, p.177

50 Frei Basílio Rower, Páginas de História Franciscana no Brasil, p.328 
conseguiram seu objetivo voltaram com seus cativos para seu convento. E independente da existência ou não de outra casa religiosa, o povo de Taubaté solicitou a fundação de um Convento Franciscano para a formação religiosa da nova vila.

Em 1673 era Custódio dos Franciscanos, nas partes do sul, Frei Eusébio da Expectação. Foi ele que atendeu ao pedido dos taubateanos, aprovando a fundação do Convento de Santa Clara. Para administrar e dirigir as obras foi destinado Frei Jerônimo de São Braz, que em 25 de abril de 1674, se lavrou uma escritura, onde os habitantes de Taubaté se comprometeram a dar o sítio que Frei Jerônimo escolhesse, e concorrer com dinheiro, materiais e operários [gentios da terra] para a obra. Tudo consta conforme a escritura que passamos a transcrever, conforme livro do Tombo do Convento de Santa Clara:

Saibam quantos este público instrumento de Escritura de Obrigação virem que no ano do Nascimento de Nosso Senhor Jesus Cristo de mil seiscentos e setenta e quatro anos, aos vinte e cinco dias do mês de abril do dito ano, nesta Vila de São Francisco das Chagas de Taubaté da Capitania de Nossa Senhora da Conceição de Itanhaém do Estado do Brasil,etc. Nesta Vila fui eu Tabelião chamado à presença dos Oficiais da Câmara, a saber Juízes, Vereadores, e Procurador do Conselho, e bem assim dos homens da Nobreza, e Povo, que presentes estavam, e sendo aí juntos com o Rdo. Padre Frei Jerônimo de São Braz, Religioso de São Francisco, que à petição deste dito povo vem fundar Convento nesta Vila, foi dito pelos ditos Oficiais da Câmara, Nobreza, e Povo que eles se obrigavam a fazer Igreja e Convento à sua custa, conforme a capacidade da terra, para que os Religiosos de S. Francisco vivessem nele, a qual obra se faria com toda a suavidade e comodidade do povo na paragem e sítio que escolhesse o dito Padre Frei Jerônimo de São Braz, fundador dele, e pelo dito Pe. Fr. Jerônimo de S. Braz foi dito que logo em se começando a por mão em obra poria de assistência três religiosos a saber, dois sacerdotes e hum Irmão Leigo para ajudarem, assistirem com sua diligência durante as ditas obras, e bem assim foi dito pelos ditos Oficiais da Câmara, Nobreza e Povo que eles davam duzentos mil réis de contado para princípio de paramentos do culto divino de que logo entregaram cem mil réis, que ficaram depositados na mão do Capitão Sebastião de Freitas, ora Sindico eleito para essas e mais esmolas, e assim mais se obrigaram a dar doze peças de gentio da terra [grifo nosso] e a fazer em o sítio escolhido, bom e de paz pacífica para o dito Convento, cêrca, e mais serventia dom toda a capacidade necessária, declarando que os cem mil réis que estão por dar os darão por dia de S. Francisco, que embora vem deste presente ano, e desta maneira se obrigaram unânimes, e conformes os ditos Oficiais da Câmara que ora são, e ao diante servirem os tais cargos com a dita Nobreza, e Povo a fazerem o dito Convento, e a Igreja, como é dito, e o dito Rdo. Fr. Jerônimo de S. Braz prometeu de cumprir, e guardar o que assim dito tem, e pediram que por devoção deste dito povo tivesse a Igreja por vocação a Senhora Santa Clara.[grifo nosso]. Em fé do que mandaram fazer este instrumento que pediram e aceitaram, e eu Tabelião aceito como estipulante, e aceitante em nome das pessoas a quem tocar possa, e são ausentes e assinaram os que presentes estavam e dele mandaram dar os traslados necessários, sendo presentes por testemunhas Gonçalo de Oliveira 
e o Capitão Jerônimo Ferreira de Melo e Antonio de Alvarenga, pessoas todas de mim Tabelião reconhecidas, que assinaram com os ditos Oficiais da Câmara, Nobreza, e Povo; e eu, Sebastião Martins Pereira, Tabelião do público, judicial, e notas nesta Vila o sobre escrevi, e assinaram todos os nomeados acima Gonçalo de Oliveira, o Capitão Jerônimo Ferreira, Antônio de Alvarenga, o Juiz Domingos Roiz do Prado, o juiz Henrique Vieira da Cunha, o Vereador Salvador de Faria Alvernes, o vereador Antonio Delgado de Oliveira, o vereador Salvador Pires Bicudo, o Procurador do Conselho Manuel Antunes Povo, Bento Gil de Siqueira, Antonio Delgado Escobar, o Capitão Gaspar Vaz da Cunha, Sebastião Vaz Cardoso, Domingos do Prado Martins, Salvador Pires de Medeiros, Bernardo Sanches Pimenta,Francisco Borges Roiz, Pedro Fragoso, João Vaz da Cunha, Pascoal Gil,Sebastião Gil, o capitam Sebastião de Freitas, o Rdo. Pe. Guardião Fr. Jerônimo de S. Braz o qual traslado de Escritura eu sobredito Tabelião fiz escrever, e sobre escrevi, corri, e consertei; à qual em tudo, e por tudo me reporto ao meu Livro de Notas, em que a lancei, que fica em meu poder, e cartório, e assinei de meus sinais público e razo, que são como parecem em o dito mês e ano em testemunho de verdade.----- Sebastião Martins Pereira. ${ }^{51}$

Um terreno de 100 braças em quadra foi doado pelo capitão Manuel Vieira Sarmento [um dos fundadores da Ordem Terceira em Taubaté], que era filho de Belquior Félix e neto de Jacques Félix, fundador da dita Vila. Mas em 1674 ele não fez escritura de doação. Fê-la com sua mulher Domingas da Veiga, em 1679, fato interessante a notificar que o local do Convento de Santa Clara foi precisamente o local onde o fundador da Vila teve o seu sítio. ${ }^{52}$

Segue a escritura:

Saibam quantos este público instrumento de escritura de doação de terras virem, que sendo no Ano do Nascimento de Nosso Senhor Jesus Cristo de mil seiscentos setenta e nove anos, aos vinte e um dias do $m$ ês de abril do dito ano, nesta Vila de São Francisco das Chagas de Taubaté da Capitania de São Vicente do Conde da Ilha do Príncipe Donatário dela por Sua Alteza etc., nesta Vila, em presença de mim Tabelião ao diante nomeado apareceu presente o Capitão Manuel Vieira Samento, aqui morador, pelo qual me foi dito presente testemunhas abaixo nomeadas e assinadas, com outorga eu Tabelião tomei a sua mulher Domingas da Veiga, que eles possuíam por carta de sesmaria dadas pelo capitão-mor e sesmeiro Dionísio da Costa e seu avô , o capitão Jaques Félix, donde o dito seu avô teve o seu sítio donde ora de presente está o Convento da Senhora Santa Clara, o qual sítio e paragem houvera ele dito dado aos Religiosos de São Francisco, para nele se fazer o dito convento [grifo nosso], com cem braças de terras em quadra como deu, e de novo por esta escritura de doação lhe confirmaram as ditas cem braças em quadra, começando da borda do tanque dos ditos Religiosos até correndo pelo sapé do outro que vai para o Ribeiro, e daí enchendo as ditas cem braças, correrão as outras cem braças até ao caminho novo que os ditos Religiosos fizeram para os campos, e daí para os campos desta vila que a tudo deram sempre as cem braças em quadra, e assim lhe largaram mais aos

51 Tombo G,I, fl.9v.

52 Frei Basílio, Paginas de História Franciscana no Brasil, p.336 
ditos Religiosos, todas as terras que se acharem a vir do dito caminho dos ditos Religiosos para cima, até entestar com as terras do Concelho, de campo a campo, e estas terras lhe largaram pelo Amor de Deus, pelas haverem os ditos Religiosos mister para seu convento e fábrica dele de que a ele dito capitão Manuel Vieira Sarmento estava haverá largos anos possuindo de paz pacífica à vista e face de todos, e ora de presente disseram que deram as ditas terras aos Religiosos de Santa Clara do convento desta vila, para que as logrem, hajam e possuam como coisa sua dada para o serviço de Deus, e de si afastaram toda a posse real e atual de que nas ditas terras tinham e de tudo dimitiam e traspassaram nas pessoas dos ditos Religiosos, e se obrigaram por suas pessoas e bens a fazerem sempre boa esta escritura e de paz pacífica, em fé do que mandaram fazer este instrumento nesta minha nota, que pediram e aceitaram. Eu Tabelião como estipulante e aceitante o aceitei em nome do Reverendo Padre Guardião deste Convento, Frei Antonio da Madre de Deus que presente estava, e nos mais a quem tocar possa, e dele mandaram dar os traslados necessários, sendo presentes partes testemunhas Pedro Dias Fernandes, Manuel Pacheco da Costa e Salvador Fernandes Cubas, pessoas de mim Tabelião conhecidas, que assinaram com o dito outorgante -----Sebastião Martins Pereira, Tabelião do público judicial e notas o escrevi e assinaram todos sobreditos acima em o dia mês e ano atrás declarado ---- Manuel Vieira Sarmento ---- Pedro Dias Fernandes ----Salvador Fernandes Cubas ----- e em falta de Manuel Pacheco da Costa, assinou Mateus Vaz da Silva: o qual traslado de escritura de doação de terras, eu sobredito Tabelião trasladei de meu livro de notas em que o lavrei, que fica em meu poder e cartório, o qual em tudo e por tudo me reporto e o corri, consertei, escrevi e assinei de meu sinal público e raso que tais são como parece, em o dito dia, mês e ano atrás declarado ---- Sebastião Martins Pereira. ${ }^{53}$

Os primeiros conflitos entre os religiosos e os colonos taubateanos surgem quando, os moradores não cumprem o prometido, as obras param e frei Jerônimo apresenta queixa ao Vigário da Vara, o Licenciado Mateus Nunes de Siqueira, residente em São Paulo, pedindo que fossem intimados os Juízes da Câmara, como executores do compromisso feito sob penas eclesiásticas e que ele, junto com o vigário de Taubaté, fosse autorizado a tomar as contas aos Juízes. ${ }^{54}$ Frei Basílio não concorda com a atitude de Frei Jerônimo com relação a esta petição. A Ordem ou a Santa Sé, não adquiriu jus ad rem, e muito menos jus in re, e em tais casos a Ordem franciscana só admite meios suasórios. Podia o Guardião usá-los e pedir ao Vigário da Vara insistisse também, mas não lhe competia recurso judicial e requerer censuras eclesiásticas. ${ }^{55}$

O Vigário da Vara, dando provimento favorável à petição do Guardião, mandou intimar os Juízes a cumprir seu dever, sob pena de

53 Escritura da doação do primeiro terreno - 1674 - lavrada em 1679 , terras doadas pelo Capitão Sarmento.Certidão no Arquivo da Província da Imaculada Conceição, p.22.In: Frei Basílio,op.cit.p.336-337

54 Ver petição na íntegra em Frei Basílio, op.cit.p.331-332

55 Frei Basílio, op.cit.p.332 
excomunhão ipso facto incurrenda e dando o prazo de nove dias, valendo por três admoestações canônicas. Vejamos a Carta Monitória na íntegra:

Carta Monitória, Mateus Nunes de Siqueira, Síndico das esmolas dos Santos Lugares de Jerusalém, Ouvidor da Vara Eclesiástica nesta Vila de S.Paulo, e seu distrito. Pelo M.r.Snr. o Doutor Francisco da Silveira, Administrador da cidade do Rio de Janeiro, e sua Diocese, etc. A todos que este monitório citatório virem ou ouvirem e as suas notícias vier saúde e paz para sempre em N.Snr. Jesus Cristo, que de todos é verdadeiro remédio, e salvação. Faço saber que a mim me enviaram a dizer por sua petição por escrito os Muito Rdos. Padres de São Francisco do Convento da Vila de Taubaté em como os moradores da dita vila prometeram as suas esmolas voluntariamente para se fazer o Convento de São Francisco para nele se recolherem, e assistirem os ditos Religiosos, e muitas pessoas moradoras em a mesma Vila ficaram de lhes dar taboado, cada qual no que foi fintado. Também prometeram e se obrigaram a assistir com seus negros as semanas cada bairro até se acabar o dito Convento; terem efetivos os ditos moradores trinta negros ao trabalho, a falta do que se não continuam as obras, nem vai a fundação por diante, o que tudo é em grande descômodo deles Religiosos, como também entre algumas pessoas, que se lhes falta com sete arrobas e dezoito libras de ferro, ao que deram e são obrigados a dar conta das ditas esmolas, e cobrá-las os Juízes Ordinários que serviram no ano de setenta e cinco, e os de setenta e seis, e os de hoje de presente servem por serem meros executores em tais causas de obrigações e prometimentos do povo; em virtude do que mandei por meu despacho se passasse como pediam, pelo qual se passou o presente, o qual sendo primeiro por mim assinado, mando ao Muito Rdo. Pe. Diogo Luís, Vigário da dita Vila de S. Francisco das Chagas de Taibaté, adjunto com o Muito Rdo. Pe. Guardião do mesmo Convento Fr. Jerônimo de S. Braz, que em cumprimento deste tomem conta das esmolas que prometeram, e cobraram, e do mais pedido da dita petição, aos seis Juízes que serviram, e servem e que fará e mandará ele Rdo. Vigário, esta diligência por qualquer Oficial de Justiça Eclesiástica ou secular para que com pena de Excomunhão maior ipso facto incurrenda, e de cinquienta cruzados dentro de nove dias primeiros seguintes, depois de lhes ser este intimado, que lhes dem, e concedo pelas três canônicas admoestações três dias para cada hua repartidamente, termo preciso e perentório, e sendo não acudam, nem venham dar contas, nem entreguem o que em seu poder tiverem de esmolas cobradas, nem obrigarem ao povo ao que tem prometido os ditos juízes a que dem satisfação ao que ficaram e se obrigaram, por esta e os hei por citados para agravação, e reagravação das mais censuras em direito permitido em tal caso, e da diligência que se fizer se passará certidão ao pé deste para que me conste para os mais procedimentos. Cumpram-se aí huns e outros sob as mesmas penas. Dada nesta Vila de São Paulo, sob o meu sinal somente aos dezenove dias do $\mathrm{M} \sim$ es de fevereiro de mil e seiscentos e setenta e sete anos, eu o Licenciado João de Paiva, escrivão do Juízo Eclesiástico, o fiz escrever, e subescrevi --- O Licenciado Mateus Nunes de Sequeira. ${ }^{56}$

A Carta Monitória foi lida publicamente na matriz de Taubaté e intimada aos Juízes, diante de tal pressão e das ameaças severas das penas espirituais, prometeram obedecer e cumprir o seu dever, como consta da seguinte certidão, passada em 15 de março de 1677: 
Certifico eu Sebastião Martins Pereira, Escrivão do Eclesiástico nesta Vila de S. Francisco das Chagas e seu termo, etc., em como é verdade que eu publiquei nesta Matriz em voz alta que foi ouvida do povo em dia festivo este monitório do Licenciado Mateus Nunes de Sequeira, Ouvidor da Vara Eclesiástica em a Vila de São Paulo, e Vilas e juntamente notiviquei a Antonio de Barros...e ao juiz Baltazar de Morais, e a Bernardo Sanches Pimenta e os notifiquei em suas pessoas por todo o conteúdo nesta monitória, e citatória, e lhes li toda, e deram por resposta que obedeciam, de que passei a presente certidão por me ser pedida aos quinze de março de mil seiscentos, e setenta e sete anos.--- Sebastião Martins Pereira. ${ }^{57}$

Diante de tudo isto as obras voltaram ao normal, sendo um dos edifícios melhores e vastos da localidade. Para sua construção concorreram além dos moradores em geral, também alguns particulares com avultados donativos.

Obedecia a construção ao estilo conventual em voga, com seu claustro quadrangular, cercado em três lados pelas oficinas de costume em baixo e pelos dormitórios em cima. Apesar do Convento ser "o maior ornato desta Vila", no dizer de Frei Apolinário da Conceição, era de dimensões pequenas em comparação com outros e nele residiam uns 15 para 20 religiosos. ${ }^{58}$

A igreja, muito modesta, fez-se com alpendre de três arcos, como tem a do Convento de S. Francisco de São Paulo, três janelas de côro e frontão em linhas retas. A torre ergue-se mais alto do que de costume e nota-se nela um estilo barroco mais pronunciado, como também nas pilastras dos arcos e nas umbreiras de cantaria emoldurada das portas.

As taipas do corpo da igreja foram feitas pelos escravos do benfeitor Domingos Cordeiro Gil, que também empreitou as taipas restantes por mais de duzentos mil réis. Após sua morte a família continuou a favorecer o Convento com suas esmolas. ${ }^{59}$ 


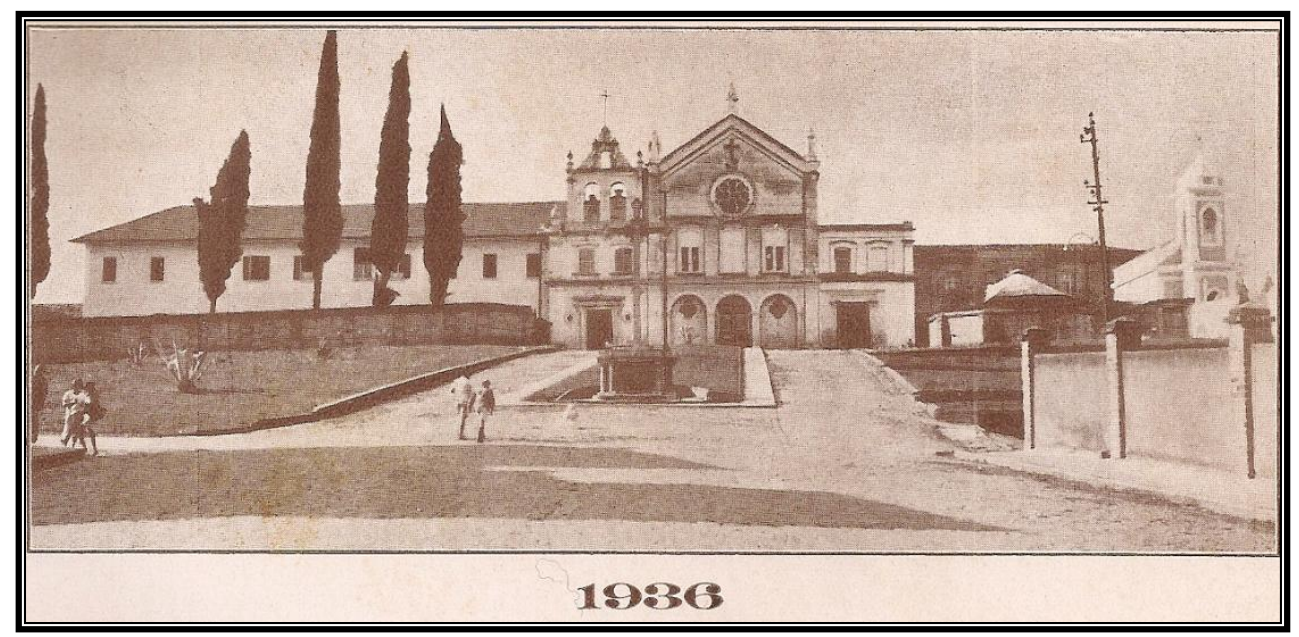

Convento de Santa Clara em Taubaté. Do lado direito da foto vê-se o cemitério da Ordem Terceira Franciscana com sua capela, ao fundo prédio da Ordem Terceira e do lado esquerdo as clausuras dos religiosos.

Dentro da igreja puseram três altares,o mor com a imagem da Padroeira, tendo uma custódia de prata na mão,e os laterais Nossa Senhora da Conceição e de Santo Antonio. No retábulo do altar-mor achavam-se em nichos laterais, as imagens de São Francisco e de São Domingos. ${ }^{60}$ No corpo da igreja venerava-se uma imagem, julgada milagrosa, de Nossa Senhora da Piedade, que em 1757 foi distinguida com indulgências. ${ }^{61}$

A Ordem Terceira da Penitência do Convento de Santa Clara foi fundada em 1677. Foram seus primeiros Irmãos e fundadores: Antonio Velho Cabral,Domingos Rodrigues do Prado, Gaspar Nunes, Antonio Bicudo Leme, Brás Estêves Leme, Antonio Delgado de Escobar, Manuel Vieira Sarmento. Ocupou o cargo de Ministro o Pe. João de Faria Fialho, do hábito de São Pedro, o famoso padre bandeirante de Minas Gerais, e serviu de primeiro Comissário Frei Antonio de Santa Clara. ${ }^{62}$

E os indígenas como se relacionavam com os capuchinhos? De acordo com a Portaria de 14 de julho de 1677, ordenava o Príncipe Regente que as Aldeias de índios fossem administradas por Religiosos e não por seculares, que escravizavam ou pelo menos exploravam o Gentio, ordem que renovou em Carta de 17 de janeiro de $1691 .^{63}$ Diferente de outros religiosos que mantinham suas atividades à suas residências e colégios, nos últimos

60 Existem ainda as imagens desta época de São Francisco e Santa Clara.

61 Tombo T., fl.33 v.-In: Frei Basílio,op.cit.p.334

62 Tombo T.fl.21 v. Poucas informações obtemos sobre esta Ordem, apenas que construíram uma capela por volta de 1720 que foi extinta na reconstrução da igreja que os Capuchinhos fizeram em 1927. In:Frei Basilio,op.cit.p.335

63 Tombo G,I,fl.91. 
decênios do século XVII, a atividade franciscana foi muito intensa nas partes do sul do Brasil. Tinha, outrossim, a Província mais missionários do que todas as outras Ordens juntas e mais línguas, quer dizer, missionários que falavam a língua indígena [tupi e não tupi] ${ }^{64}$.

Em Taubaté os índios viviam dispersos [fugidos, espalhados pelo sertão, em outras fazendas, sem líder] e convinha aldeiá-los. O Convento de Santa Clara recebeu esta tarefa, confiada ao seu Guardião [Frei Antonio da Purificação] e seus sucessores. Fê-lo o Capitão-mor e Governador da Capitania de Itanhaém, Martim Garcia Lumbria, o mesmo que incumbiu os franciscanos também da Aldeia de São João de Peruíbe. ${ }^{65}$ Segue adiante Provisão do Capitão-mor de 12 de julho de 1692 :

Faço saber aos que esta minha Provisão virem que porquanto convém ao Serviço de Sua Majestade prover a administração dos índios que há nesta Vila de Taibaté para deles se formar Aldeia nova e administrador Religioso para que melhor trate do bem espiritual de suas almas, como o Governo Geral deste Estado me encomenda em seu Alvará ; hei por bem eleger e nomear por Administrador dos índios de Sua Majestade ao Rdo. Pe. Guardião do Convento de Santa Clara desta Vila Fr. Antonio da Purificação ${ }^{66} \mathrm{e}$ a todos os seus sucessores para que como tais os possam haver das casas dos moradores desta dita Vila, onde quer que estiverem, e aldeiálos onde mais lhe convier, ficando os ditos índios somente sujeitos a quaisquer ocasiões que se oferecerem do Real Serviço de Sua Majestade, ou dos Oficiais do Senado da Câmara desta Vila.Não poderá pessoa alguma de qualquer qualidade que seja entender com os ditos índios, nem administrálos mais que o Rdo. Ped. Guardião e haverá a dita administração enquanto Sua Majestade ou o Governo Geral não mandar o contrário, a quem faço aviso do que nisto obro. Como em seu alvará me encomenda. E em virtude desta o hei por empossado dos ditos índios, e ordeno aos oficiais do Senado da Câmara desta Vila lhe dêm, e façam dar inteiro cumprimento, e se registrará nos livros que tocar de que se fará assento nas costas desta. Para firmeza do que mandei passar a presente sob meu sinal e selo de minhas armas nesta Vila de S. Francisco das Chagas de Taibate em os doze dias do mês de julho de mil seiscentos e noventa e dois ----- Martim Garcia Lumbria --- Cumpra-se e registre-se, etc. ${ }^{67}$

De acordo com Frei Basílio, nada consta dos documentos do antigo arquivo provincial, nem tão pouco os autores que foram consultados esclarecem sobre onde os Franciscanos localizaram a Aldeia dos índios ou até quando a dirigiram. Como estava entregue ao Guardião, as tábuas capitulares não mencionam um padre especial destacado para dirigi-la. ${ }^{68}$

64 Tombo, I, fl.89v.

65 Tombo Itanhaém,fl.26v. Ver também Félix Guisard, O Convento de Santa Clara,p.34.

66 Frei Antonio da Purificação era taubateano, irmão da segunda mulher de Antônio Bicudo Leme, D. Luísa Machado. Pertencia, a uma família da elite local.

67 Tombo T, fl4v.

68 Frei Basílio,op.cit.,p.339 
Interessante fato se faz ressaltar de um litígio acerca do terreno de frente ao Convento no período de 1720. Os conflitos aconteceram entre os Franciscanos na figura do síndico Gaspar Pereira de Castro, representando o Convento e o Capitão Antônio de Aguiar Ferreira. Este processo volumoso que encontramos no livro do Tombo do Convento de Taubaté, disputa 250 braças de terra em frente ao convento. Após construído o Convento, passado dez anos em 1684, o Guardião Frei Francisco de S. Lourenço pediu para "melhoramento e cômodo do Convento" duzentas braças de capão das terras do Conselho, que ficavam em frente do Convento. A Câmara despachou favorecendo os religiosos em 25 de março do mesmo ano. Frei Domingos pedira ao Capitão-mor e Governador Antonio Caetano Pinto Coelho, a renovação da doação das ditas 200 braças, mais a sua nova concessão, e foilhe passada Carta de sesmaria de 250 braças em 10 de fevereiro de $1720,{ }^{69}$ ou seja, 550 metros de testada, começavam na estrada da vila ao dito capão e nos lados iam de campo a campo, ou da estrada de Tremembé até à estrada de Maria Bicuda [estrada de Cavarucanguera, ver mapa da localização no item 3.2 onde mostra a primitiva aldeia Guaianá], e dentro existia uma lagoa. ${ }^{70}$

69 Segundo frei Basílio,Petição e Carta de Sesmaria acham-se por certidão extraída em 08/11/1801 no antigo arquivo da Província. Frei Basílio,op.cit.p.342

70 Felix Guisard não esclarece com certeza esta localização, ver em O Convento de Santa Clara,p.34 


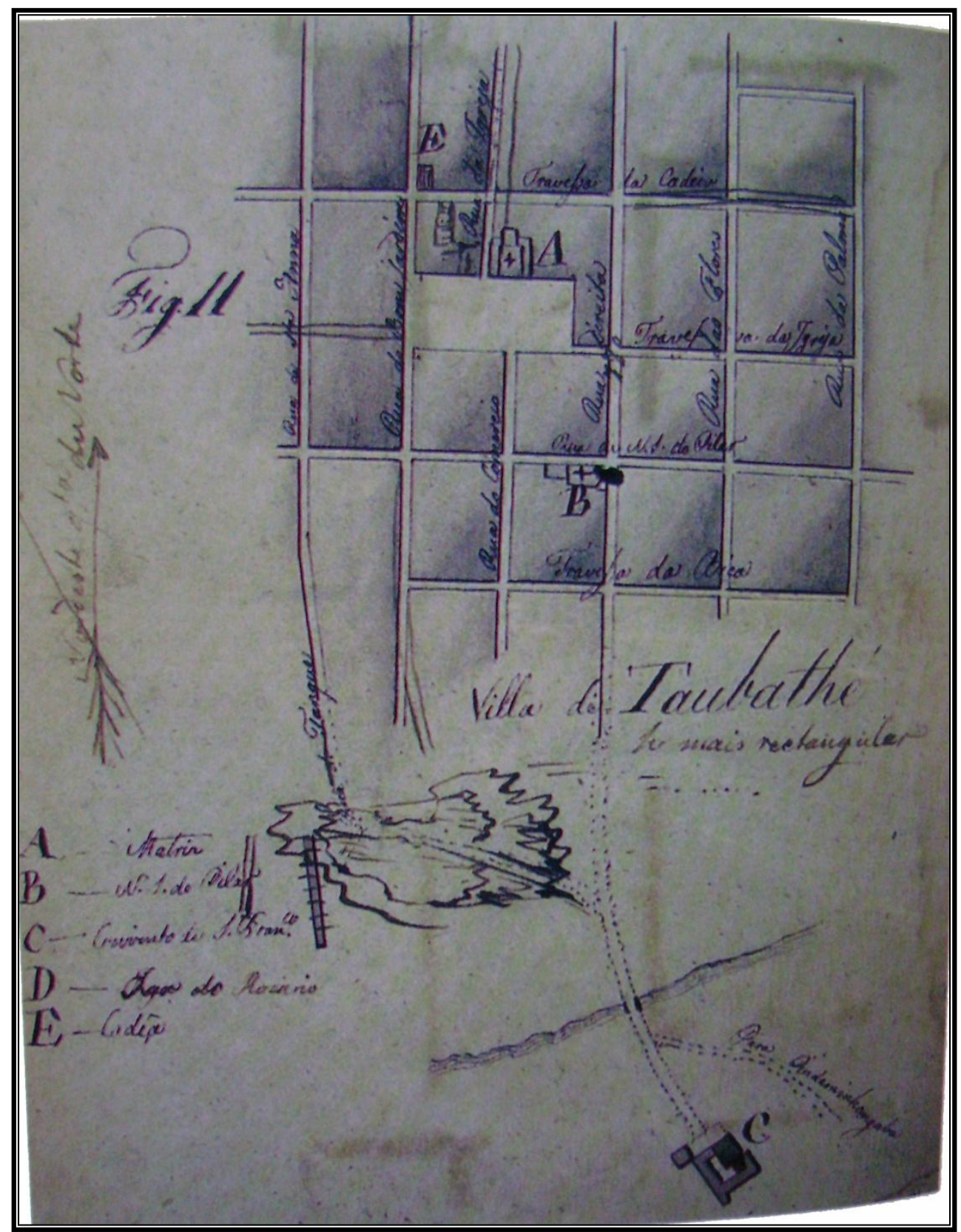

Vila de Taubathe, desenho de Arnaud Julien Pallière, em 1821, existente no Instituto de Estudos Brasileiros na USP.

De acordo com José Bernardo Ortiz, esta lagoa foi registrada em 1821 pelo pintor francês Palliére, que em seu desenho indicou como Tanque, que na verdade era uma área alagadiça que existia em frente ao Convento de Santa Clara. Esse alagadiço desapareceu em 1908, quando canalizado pelo Prefeito Dr. Gastão Câmara Leal. Depois essa canalização ruiu, sendo substituída por duas linhas de tubos de concreto de 1,20m de diâmetro, já em 1987, feitas assentar pela Prefeitura no período de seu mandato como prefeito. Veja acima a planta de Taubaté feita por Pallière. 
Os conflitos não cessam, logo depois da Câmara ter confirmado aos Religiosos a doação de 1684, apresentou-se o Capitão Antonio Aguiar Ferreira em defesa dos direitos que dizia ter sobre as terras de frente ao Convento. $\mathrm{O}$ caso era complicado, porque a mesma Câmara tinha aforado as mesmas terras desde 1717 a diversos moradores, ignorando a verdadeira situação. O Capitão, alegava dizendo ter comprado estas terras em 1719 a Francisco da Silva e julgou-se foreiro em virtude do despacho da Câmara, que considerava as terras devolutas, mas que não passou ao Capitão Carta de aforamento. O Capitão, fizera benfeitorias, no local, cercando o mato e abrindo valas nos limites, com que tornou as terras inacessíveis aos pobres. As petições e ajuntamento de documentos sucederam um após outro, até que os autos foram conclusos aos oficiais da Câmara no 15 de março de 1720, em 23 de março do mesmo ano lavrou-se a sentença em Câmara, dando ganho de causa ao Convento, por apresentar melhores títulos e o Capitão foi condenado nas custas e a remover as benfeitorias feitas depois da compra a Francisco da Silva. Foi ainda censurado por cercar os matos em detrimento dos pobres, o que era contra as leis do Reino.

O Capitão não se conformou, que opôs embargos, porém a sentença foi confirmada pelos oficiais da Câmara em 15 de abril, "sem embargo dos embargos". O Capitão, agravou no mesmo dia dos oficiais da Câmara para o Ouvidor Geral da Comarca, “ pela falta que há nesta Vila de Letrados”. Disto deu-se vista ao procurador do síndico, Pe. João de Sousa Rangel, que respondeu que o Capitão não guardou o prazo da lei e que, devia ser condenado sem apelação nem agravo e o síndico empossado nas terras. Em 29 de abril, foi dada a segunda sentença [favorecendo os Religiosos] pelos oficiais : João Pires de Brito, Paulo Vieira de Maia, Manuel Garcia de Peralta, Manuel da Silva Leme. Acabando a disputa pelas terras, o Guardião Frei Domingos do Rosário, principal zelador dos interesses do Convento, foi transferido na Congregação Intermédia de 1721 para outro Convento. O novo Guardião, Frei Agostinho de S. Catarina, passou em julho de $1721 \mathrm{em}$ favor do Deão e Vigário da Vara Lourenço de Toledo Taques. ${ }^{71}$

Não sabemos se nestas terras aconteceu a criação da nova Aldeia administrada pelos Franciscanos. Sabemos que nesta disputa de um longo processo o Convento saiu vencedor.

71 Tombo T, fls 6 a 21v. 
Outro fato interessante que ocorreu por volta de 1722, foram conflitos entre os escravos do Convento e os almotacéis ${ }^{72}$ sobre a fuga de porcos que pertenciam ao Convento de Santa Clara. O Guardião do Convento, envia uma petição ao Ouvidor Geral, esclarecendo que "à vezes recebia de esmola alguns porcos que os benfeitores traziam enchiqueirados em cercado. Mas acontecia dos animais fugirem, indo passear pelas ruas da vila, sendo então mortos pelos almotacéis, no que tinham recebido notável prejuízo. Do mesmo modo, sofriam dano pelos seus escravos, que roubavam quantas coisas podiam e os vendeiros lhe compravam os objetos roubados. Pediam, por isto, que o Ouvidor proibisse a matança dos porcos e estabelecesse penas para os que negociassem com os escravos do Convento.” O Ouvidor não pode deixar de atender e decretou: “ (...) Sob pena de se lhes pagar o valor dos porcos em dobro, para que se notifique este despacho aos almotacéis; e quem contratar com as pessoas da Comunidade, além de pagar em dobro o que lhes aceitam, esteja vinte dias na cadeia. Taubaté,28 de junho de 1722."73

Embora seja início dos setecentos interessante refletirmos como havia porcos em quantidade na Vila de Taubaté, dentro de um mercado que crescia favoravelmente com o ouro das Minas Gerais, estas posturas eram criadas em grande quantidade para suprir o alimento da Vila e era exportado para outras regiões próximas a ela. ${ }^{74}$

Com relação a educação do povo da vila, foi criado por volta de 1730 , conforme frei Apolinário da Conceição nos relata três conventos com semelhantes estudos : Cabo Frio, Macacu e Taubaté. No Convento de Santa Clara, assistiam 16 religiosos em que entram alguns defensores da língua da terra para confessar o gentio dela, concorrendo por esta causa, principalmente de outras vilas, em tempo de quaresma muitos a este convento a desobrigar-se do preceito da Igreja, e assim também há um religioso mestre que ensina a ler, escrever e a contar aos meninos desta vila e a outros gramática. De fato, acrescenta Frei Apolinário que destas aulas tem saído muitos clérigos e Religiosos nossos e da Companhia de Jesus,

72 Almotacé - Inspetor de pesos e medidas que fixava o preço dos gêneros alimentícios. In: Aurélio Buarque de Hollanda Ferreira. Pequeno Dicionário Brasileiro da Língua Portuguesa, 1977,p.57

73 Tombo T,fl.22 v.

74 Ver a grande criação de porcos nos inventários de Amaro Gil, caixa 2, doc.27 de 1685 e de Catherina Portes d'el Rey, caixa 2, doc.37, de 1687, ambos investiam da criação para abastecer as comitivas que seguiam direção a região das minas. 
donde também é lícito inferir que as aulas funcionavam muito antes de $1730 .^{75}$

Havia o interesse do Convento em alfabetizar o povo, mas investiam nos futuros missionários que dariam seqüencia nos trabalhos franciscanos, tanto que em 1897 abriu-se um externato sob nome de Colégio Seráfico, cujo fim era o de formar Missionários Capuchinhos, recebendo daqueles meninos que mostravam vocação para este fim, mas era e são excluídos todos aqueles que em lugar de vocação tem só locação. Deste colégio saíram vários sacerdotes, permaneceu em funcionamento em Taubaté até 1910, onde fora transferido para Piracicaba, depois São Paulo e depois voltou para Piracicaba em prédio próprio. ${ }^{76}$

\subsection{Os cativos indígenas dos colonos de Taubaté no período de 1640 a 1699}

Sendo ponto central das rotas que se dirigem de São Paulo ou Parati para as Minas, pelo chamado "caminho velho", muito utilizado até a construção do "caminho novo de Garcia Paes", a vila de São Francisco das Chagas de Taubaté destacou-se como um importante centro de incursões sertanistas. O período/local desta pesquisa foi assim selecionado por ser um elo entre São Paulo - Vale - Minas - Rio de Janeiro (via Parati) e por ocorrer na formação das vilas após 1640 uma grande quantidade de incursões de apresamento indígena. Outro fator foi a formação de novos povoados e vilas seguindo os caminhos destas armações que também visavam a procura pelas minas de ouro, prata, diamantes.

Ao analisar os testamentos e inventários seiscentistas de Taubaté procuramos estudar as relações de trabalho que envolveram os primeiros colonos da região. Com a mudança na organização do apresamento aconteceu o aumento no fluxo de cativos indígenas de várias nações nos plantéis destes colonos. É difícil calcular com exatidão a dimensão do tráfico de escravos para este período, porém a tabela 1 mostrará a possível quantidade de cativos que cada proprietário possuía. Vejamos:

75 Frei Apolinário da Conceição. Epítome da Província da Conceição do Brasil, 1730.Este manuscrito se encontra na Biblioteca Nacional do Rio de Janeiro.

76 Felix Guisard, O Convento de Santa Clara, p.159. 
TABELA 1 - Distribuição dos índios, 1640-1699

\begin{tabular}{|l|l|l|l|l|l|}
\hline $\begin{array}{l}\text { Quantidade de cativos } \\
\text { por proprietários }\end{array}$ & $\begin{array}{l}\mathrm{N}^{\mathrm{o}} \text { Prop } \\
(\mathrm{n} *) .\end{array}$ & $\mathrm{H}$ & $\mathrm{M}$ & $\mathrm{C}$ & Total \\
\hline 1 a 5 & 27 & 27 & 34 & 15 & 76 \\
\hline 6 a 10 & 27 & 76 & 94 & 33 & 203 \\
\hline 11 a 15 & 16 & 62 & 84 & 58 & 204 \\
\hline 16 a 25 & 19 & 144 & 175 & 61 & 380 \\
\hline+26 & 22 & 474 & 560 & 399 & 1433 \\
\hline Total & 111 & 783 & 947 & 566 & 2296 \\
\hline
\end{tabular}

$\left(n^{*}\right)=n^{o}$ de proprieários na faixa de quantidade de cativos

FONTE: Caixas 1 a inventários e testamentos de Taubaté séc.XVII

A partir do momento que a região de Taubaté passa ser local de abastecimento para as armações paulistas, e por ordem da Condessa de Vimieiro em doar sesmarias ao capitão Jacques Félix e assim autorizou o mesmo a doar terras para administrar melhor suas fronteiras, muitas famílias paulistas se fixaram na região e passaram a investir nas armações para o sertão, agora com o objetivo de manter suas fazendas com braço indígena. $\mathrm{O}$ que se destaca nesta tabela é a presença maciça de mulheres e crianças. Era costume entre os colonos e caciques negociarem mulheres e crianças através do escambo, costume este que durou por longo tempo, pelo século XIX a dentro. A cessão de crianças índias pelos próprios pais - em troca de um machado, de açúcar ou de cachaça, com o engodo de que depois seriam trazidas de volta - era habitual em Minas Gerais, na região do Jequitinhonha, conforme registrou Saint-Hilaire. Os pequenos índios, assim obtidos, eram a seguir vendidos pelos traficantes nas povoações. ${ }^{77}$

Na região de Taubaté o trabalho feminino e infantil foi aproveitado nas lavouras e na pecuária, esta divisão do trabalho foi assim escolhida por aproveitar o costume indígena onde as mulheres na tribo tinham a função em trabalhar no plantio e colheita, os cativos homens foram aproveitados para outras profissões especializadas, tais como o transporte de cargas e participação nas expedições de apresamento e prospecção de minérios no sertão bem como outros ofícios :

77 Jacob Gorender, O escravismo colonial, p.496 
No rol das pessas do gentio da terra temos:

Fernando e sua mulher Serafina filho Jose já rapaz pagem, Jacinto solto, João solto, Antonio sua mulher Ignacia filho Ignassio pagem, Isabel solta filha Marcelina pagem.

Alvidraçao

Foi alvidrado o serviço de João solto o serviço de João digo com sua alvidraçao de $18 \$ 000$ (...) o serviço de Marcelina pagem em $6 \$ 000^{78}$

Foi alvidrado o serviço declarado negro da terra oficial de fexeiro em sua alvidrassao em 32 mil reis. $^{79}$

Josepe solto, Fabio solto ambos andam nas minas com Artur da Rocha [transporte de cargas] ${ }^{80}$

Não se achou entre o cazal mais que hum negro do gentio da terra por nome davy e sua mulher fellicia com hua cria por nome serillo e o dito negro esta no sertam com seu genro Francisco dias......[participação em expedições de apresamento e prospecção de minérios] ${ }^{81}$

(...)mandou o juiz ordinário Bernardo Sanches Pimenta apregoar (pregão de leilão)por hu mosso seu negro da terra por nome Pascoal huas luvas brancas cantando de lanço em lanço[cantando o leilão de rua a rua] na forma da ordenação $^{82}$

negro ferreiro do gentio da terra por nome Ignosencio,(...) negro seleiro do gentio da terra por nome Dimas(..)teselao negro do gentio da terra por nome Luis (...) Asenço carpinteiro em sua alvidrassao......25\$000 $0^{83}$

Com a reorganização do apresamento, as expedições de grande porte passaram a dar lugar as pequenas armações, de modo que essas expedições passaram a ser de menor porte, mas freqüentes e mais dispersas em termos geográficos. Na medida que os paulistas viam-se obrigados a substituir a mão-de-obra Guarani por outros índios, algumas expedições adentraram nos sertões de Taubaté e sertões dos Cataguás assim aumentando seus plantéis indígenas de nações diversas que não falavam o tupi.

78 Inventário de Antonio de Madureira Moraes, cx.3 doc.6,1692

PAGEM - 1. Moço de acompanhar pessoa nobre, que ia para a guerra, levando-lhe a lança, escudo. Moço de acompanhar, de levar recados.- 2. Menino ou rapaz que outrora se punha a serviço de pessoa de alta categoria.6. Criado que acompanha alguém em viagem a cavalo. Dic.Aurelio Buarque de Holanda ,p.1248

79 Inventario de Bertholomeu da Cunha Gago, cx 2 doc.02, 1685.Este sertanista acompanhou a Bandeira de Fernão Dias Paes ao Sabarabuçu

80 Inventario de Cornélio da Rocha, cx 3 doc.30, 1699

81 Inventario de Francisco Gonçalves Delgado, Cx 2 , doc.18, 1684

82 Inventario de João do Prado Martins, cx 01 , doc.4, 1653

83 Inventario de Martha de Miranda cx.2 doc.45,1689 
TABELA 2 - Proprietários e índios, região de Taubaté (1600-1699) segundo os inventários de bens

\begin{tabular}{|l|r|r|r|}
\hline DÉCADA & PROPRIETÁRIOS & \multicolumn{1}{|l|}{ ÍNDIOS } & POSSE MÉDIA \\
\hline $1600-9$ & - & - & - \\
\hline $1610-9$ & - & - & - \\
\hline $1620-9$ & - & - & - \\
\hline $1630-9$ & - & - & 8 \\
\hline $1640-9$ & 1 & 8 & 18,4 \\
\hline $1650-9$ & 9 & 166 & 9,8 \\
\hline $1660-9$ & 24 & 236 & 13 \\
\hline $1670-9$ & 25 & 329 & 30 \\
\hline $1680-9$ & 41 & 1239 & 10,86 \\
\hline $1690-9$ & 30 & 326 & $\mathbf{1 7 , 7 2}$ \\
\hline $\mathbf{1 6 0 0 - 1 6 9 9}$ & $\mathbf{1 3 0}$ & $\mathbf{2 3 0 4}$ & -13 \\
\hline
\end{tabular}

FONTE: Caixas 1 a 3 inventários e testamentos de Taubaté séc.XVII

Os custos materiais e humanos das expedições com destinos afastados tornaram pouco rentáveis, mesmo assim alguns colonos taubateanos chefiaram ou enviaram armações para o sertão. Com a queda do abastecimento da mão-de-obra Guarani, os Guaianás,Guarulhos,Puris, Carijós, entre outros grupos fizeram parte dos plantéis agora dos colonos da vila de São Francisco das Chagas de Taubaté. As oscilações na Posse Média da tabela 2, se deve as várias armações estarem no sertão das minas gerais e os cativos que permaneceram mantinham a produção nas fazendas que serviam de entreposto para abastecimento das incursões que por ali passavam.

Ao analisar a tabela 3 , comparamos os dados de São Paulo, Santana de Parnaíba e Taubaté, onde a partir de 1640 houve um aumento dos cativos indígenas homens principalmente na região de Taubaté. Aconteceu nesse período várias investidas para o sertão, já na década de 50 houve uma inversão de cativos para maioria feminina e a vila de Taubaté permanece neste controle favorecendo as unidades produtivas da região que aproveitaram o surgimento de novos povoados para ampliar e estruturar seu comércio com outras regiões. 
TABELA 3 - Razão da masculinidade (*) da população adulta indígena. Taubaté 1640-1699

\begin{tabular}{|c|c|c|c|}
\hline DÉCADA & SÃO PAULO & $\begin{array}{l}\text { SANTANA } \\
\text { PARNAÍBA }\end{array}$ & TAUBATÉ \\
\hline $1600-19$ & 82,7 & ------------ & -------------- \\
\hline $1620-9$ & 88,0 & ------------ & --------------- \\
\hline $1630-9$ & 92,8 & 65,6 & -------------- \\
\hline $1640-9$ & 90,0 & 75,5 & 150,0 \\
\hline $1650-9$ & 108,7 & 82,0 & 77,77 \\
\hline $1660-9$ & 92,7 & 108,6 & 66,0 \\
\hline $1670-9$ & 98,1 & 114,9 & 80,2 \\
\hline $1680-9$ & 99,5 & 84,4 & 84,8 \\
\hline $1690-9$ & --------- & --------------- & 88,8 \\
\hline
\end{tabular}

(*) n ${ }^{\circ}$ de índios adultos para cada 100 índias adultas no conjunto de inventários FONTE Caixas 1 a 3 inventários e testamentos de Taubaté séc.XVII

TABELA 4 - Composição da população indígena por grupo étnico

\begin{tabular}{|l|r|r|r|r|}
\hline GRUPO & \multicolumn{1}{|l|}{ HOMENS } & MULHERES & CRIANÇAS & H/100 $\mathbf{~}^{*}$ \\
\hline CARIJÓ & 1 & 8 & 5 & 12,5 \\
\hline GUAIANÁ & 1 & 3 & 4 & 33,3 \\
\hline TABAJARA & 10 & 9 & 4 & 111,11 \\
\hline GUARULHOS & 2 & 1 & 0 & 200 \\
\hline CATAGUÁ & 0 & 2 & 0 & 0 \\
\hline QURICAIO & 2 & 1 & 0 & 200 \\
\hline PURI & 6 & 3 & 6 & 200 \\
\hline GUINÉ & 8 & 3 & 3 & 266,6 \\
\hline não definidos & 758 & 921 & 544 & 82,3 \\
\hline TOTAL & $\mathbf{7 8 8}$ & $\mathbf{9 5 1}$ & $\mathbf{5 6 6}$ & $\mathbf{8 2 , 8}$ \\
\hline
\end{tabular}

H/100 M* : razão de masculinidade da população adulta.

FONTE: Caixas 1 a 3 inventários e testamentos de Taubaté séc.XVII 
Devido a grande concentração de armações saindo de São Paulo e Vale em direção a região mineradora houve interesse em cativar indígenas a princípio Guarani, mas o que encontraram foram nações diversas que não conheciam o tupi, pronunciavam outros idiomas desconhecidos pelos sertanistas, esta situação dificultará o controle sobre os indígenas nas unidades de produção favorecendo as fugas, bem como facilitará o domínio hegemônico do colono sobre seus plantéis. Observamos na tabela 4 que existe a predominância de mulheres indígenas de nações diversas bem como homens Tabajara, os grupos de nações Não Definidas entendemos que fazem parte de um grande número de indígenas de diversas nações, havia na região valeparaibana devido "as guerras justas" um grande nomadismo entre as aldeias fato este que demonstra uma reação por parte das nações indígenas evitando o confronto com os sertanistas.

A nova situação teve implicações graves no que diz respeito ao controle social nas fazendas de Taubaté. Basta constatar que a incidência de rebelião e fugas aumentou, fatos relacionados a composição étnica dos grupos cativados. Notamos que todas as revoltas daqueles anos tiveram Guaianá, Guarulhos,Puri,Carijós entre outros como protagonistas da história valeparaibana. Para muitos especialistas, a fuga representa uma forma bem caracterizada de resistência ao sistema escravista colonial; ao mesmo tempo, ela também indicava um grau de integração bastante avançado. Esta declaração choca-se com a visão convencional da historiografia brasileira que, desde há muito, sustenta a hipótese de que os índios eram muito mais propensos a fugir das fazendas do que sua contrapartida africana, já que eram nativos do Brasil e sua cultura "atrasada" impedia a adaptação dos mesmos aos rigores do trabalho forçado.Mas a análise das fugas de índios em São Paulo mostra que, pelo contrário, existia uma semelhança marcante entre São Paulo e outros locais onde floresceram sociedades escravistas.

Diversos motivos podiam estimular a fuga de um escravo. Maustratos, o desejo de se reunir a parentes que viviam numa outra fazenda ou mesmo o anseio de ser livre, todos surgiam como motivos para o abandono do senhor.

Os métodos de violência e submissão empregados aos escravos neste período representava apenas um aspecto da complexa relação entre senhores e escravos. Sem este sistema, o controle da população cativa tornar-se-ia inviável.. Tais mecanismos estavam assentados no discurso paternalista dos colonos, o qual visava sempre justificar o direito de domínio sobre os índios. Mais do que um simples discurso, esta postura mostrava-se presente 
na prática, na medida em que os senhores procuravam estabelecer laços extra-econômicos com seus escravos, com a finalidade de impor alguma estabilidade às frágeis estruturas do sistema escravista. Contudo, as posturas protetoras adotadas, longe de serem incompatíveis com a exploração econômica, antes reforçavam a relação desigual que movia o sistema de produção. ${ }^{84}$

\subsection{Cultura de subsistência ?}

Parte da historiografia brasileira cristalizou a imagem da São Paulo Colonial como uma sociedade isolada, voltada à subsistência, mas igualmente altiva, independente e até democrática. Ilana Blaj na sua Trama das tensões, critica os escritos de Alfredo Ellis Jr. e sua filha Miriam Ellis na permanência dessa imagem cristalizada da região do Planalto de Piratininga. Quanto ao isolamento e à auto-suficiência cita Ellis Jr. :

De fato, foi a Serra do Mar que impediu o intercâmbio comercial do Planalto com o exterior. (...) Só seria possível a travessia da Serra por parte de mercadorias levíssimas, ou então que se autotransportassem. Disso nasceu não só a autarquia do Planalto, mas também o bandeirismo de preá. ${ }^{85}$

Quanto a Miriam Ellis, em ensaio publicado na coleção História geral da civilização brasileira, Illana Blaj ressalta que a autora retoma a idéia da democracia em São Paulo, nos seus dois primeiros séculos, justificando pela mestiçagem, predominância da pequena propriedade, pelo espírito de cooperação dos homens paulistas e pela administração exercida pelo próprio povo. ${ }^{86}$

No entanto contestando a tese da auto-suficiência e do isolamento Charles R. Boxer afirma que São Paulo não se achava, de modo algum, tão fora do mundo, e tão completamente alheio ao que se passava no resto da colônia como Alfredo Ellis Jr, nos querem fazer acreditar. ${ }^{87}$

É Sérgio Buarque de Holanda que analisa e interpreta São Paulo colonial de forma inovadora. Ele rejeita a tese de um progresso linear, evolutivo, que teria caracterizado nosso passado colonial, a ponto de

84 John Monteiro,Negros da Terra, p.187

85 Alfredo Ellis Jr. A economia paulista no século XVIII.O ciclo do muar; o ciclo do açúcar. In: Alfredo Ellis Jr e Myriam Ellis .A economia paulista no século XVIII, p.40-41.

86 Myriam Ellis. As bandeiras na expansão geográfica do Brasil. In: Sergio Buarque de Holanda, Historia Geral da Civilização Brasileira p.281..

87 Charles R. Boxer, Salvador de Sá e a luta pelo Brasil e Angola (1602-86), p.42. Ver também Raymundo Faoro, Os donos do poder. Formação do patronato político brasileiro,v.1,p.149, onde o autor enfatiza a administração da Coroa em toda a expansão territorial, seu controle dos sertões, do apresamento indígena, e investimento na procura de minérios, "o rei queria súditos e não senhores, soldados e não caudilhos". P.164 
obliterar as diferenças e localismos, produzindo as famosas sínteses de nossa história colonial. Por outro lado, critica igualmente a visão ufanista que ressalta a braveza, o espírito indômito e empreendedor do paulista. ${ }^{88} \mathrm{Em}$ Monções, o autor comenta que para sobreviver no novo meio e perseguir o seu sonho, o colonizador é obrigado a rebaixar seu patamar de civilidade e retrocede a padrões rudes e primitivos . Só muito aos poucos, embora com extraordinária consistência, consegue o europeu implantar, num país estranho, algumas formas de vida, que já lhe eram familiares no Velho Mundo. ${ }^{89}$ É a sabedoria indígena que trabalhará o cotidiano do paulista, alertando para os perigos dos sertões, indicando os caminhos, ensinando-os a caçar, pescar, coletar o mel. É pelo convívio com o indígena que o conquistador europeu aprenderá os sinais da floresta, as pistas, as maneiras de sobrevivência nos sertões.

A expansão territorial de acordo com Sérgio Buarque de Holanda ocorreu pelas necessidades do colono paulista buscar solos férteis para o plantio e mão-de-obra indígena para suas lavouras, bem como buscar os minérios tão sonhados e escondidos no sertão, o "equilíbrio vital" para o autor. Nada é fixo, nada é definitivo, mas um “vir a ser"constante.

88 Ilana Blaj. Pulsações, sangrias e sedimentação : Sérgio Buarque de Holanda e a análise da sociedade paulista no século XVII. In: Arlinda Rocha Nogueira et al. (org.). Sérgio Buarque de Holanda. Vida e obra.p.83.

89 Sérgio Buarque de Holanda, Monções, p.20. 


\section{CONSIDERAÇÕES FINAIS}

Todo este movimento de expansão, no qual a vila paulistana exercia o papel de dupla articulação - com o litoral e com o interior - garantiu a continuidade das atividades comerciais e tornou possível a tributação dos colonos, outro interesse central da Coroa.

Assim, pela mercantilização crescente da área Planaltina, torna-se claro o papel e a articulação de São Paulo nos quadros do antigo sistema colonial. A vila seria, por um lado, agente da colonização, levando a conquista a núcleos mais distanciados, permitindo dessa forma a sua integração ao Império Português; por outro, mediante suas atividades produtivas e mercantis, garantiria o abastecimento das áreas exportadoras e interioranas, além de prover o sustento dos funcionários da Coroa, sempre presentes na região, tanto para normatizá-las, quanto para buscar indicativos da existência dos metais, esperança presente na colonização.

O papel dos paulistas na expansão da colonização para o interior e na fundação de novas vilas [na região do Vale do Paraíba Paulista e sul de Minas Gerais] relativiza, e muito, visões mais tradicionais acerca do despovoamento da vila durante o século XVII. Esta expansão não despovoou a região paulistana, ao contrário, articulou-a constantemente aos novos núcleos por meio do comércio, dos múltiplos caminhos que foram se constituindo, da integração dos bairros rurais ao dinamismo da vila, fortalecendo assim o núcleo gerador de Piratininga [e as futuras vilas paulistanas].

Povoando e articulando as regiões mais longínquas, ampliando o seu núcleo gerador pela incorporação dos bairros rurais, tendo contatos comerciais constantes com as demais vilas da região, abastecendo as áreas litorâneas, sustentando a sua própria população e os funcionários da Coroa, assegurando o posterior desenvolvimento das minas, a vila paulistana [como a vila de Taubaté] cumpre, assim, importante papel nos quadros do antigo sistema colonial, viabilizando a construção do Império Português na colônia, vasta empresa, da qual o colono necessariamente fez parte.

A produção de farinhas, milho, feijão e outros gêneros alimentícios; a criação do gado e a elevação no preço da carne; a licença obtida para a venda da aguardente de milho local; a articulação com outros núcleos regionais acarretando tanto a falta de víveres quanto uma carestia crescente; 
um comércio variado de artigos importados; a constante preocupação das autoridades com o mau estado dos caminhos, pontes, aterrados, entradas e saídas da vila; a articulação entre caminhos-bairros e a concessão do monopólio dos gêneros molhados a contratadores que se dispunham a pagar taxas elevadas a título de subsídios para a Câmara; a eterna luta entre Coroa, jesuítas e moradores a respeito da utilização da mão-de-obra indígena e do aforamento de suas terras; a expansão da propriedade e maiores indicativos de riqueza nas mãos dos clãs parentais são indicativos de um quadro de mercantilização crescente que provoca a concentração de terras e de mãode-obra, bem como de riquezas nas mãos de uma elite local, acarreta a desigualdade social e o aumento do contingente de homens livres e pobres na vila e no seu termo.

Esse processo de mercantilização conheceria, um dinamismo ainda maior mediante a articulação com a área [do Vale do Paraíba] e a área mineratória, mas esta não é, de forma alguma, a responsável por aquele. É o desenvolvimento da vila de São Paulo e de seus arredores que explica a possibilidade do abastecimento do mercado mineiro, e não o contrário. ${ }^{1}$

Na região do Vale do Paraíba, em especial os sertões de Taubaté, foi de grande predominância a instalação da ordem franciscana que colaborou para a aculturação do indígena através de sua catequese. Os jesuítas como foi mencionado em capitulo anterior gerou vários conflitos com os colonos paulistas, favorecendo as outras ordens religiosas como a de Nossa Senhora do Carmo e Franciscana aproximarem mais da vida social e política das vilas paulistanas. A mão-de-obra escolhida para abastecer suas fazendas e convento foi a indígena, não que o negro africano não fosse utilizado, pelo contrário, o estereótipo do índio incapaz convinha à Coroa e aos traficantes, que tinham no comércio de africanos fabulosa fonte de lucros.

Os aldeamentos permanentes de indígenas interessavam particularmente à Coroa e às autoridades coloniais. Além de abastecerem os colonos de gêneros alimentícios e constituírem viveiros de força de trabalho baratíssima para obras públicas, deviam os índios aldeados servir como tropas de guerreiros na defesa da colonização portuguesa contra tribos hostis e incursões de súditos de potências estrangeiras.E ainda, seriam muito úteis à repressão dos negros rebeldes e aquilombados. Do ponto de vista legal, eram os índios aldeados homens livres, postos numa condição de tutela. Obrigados ao trabalho, costumavam ser empregados na execução de obras públicas ou cedidos a particulares em regime de salário.Nasceu o sistema de 
administração confiada a particulares, análogo ao das encomiendas espanholas, embora sem sua conformação jurídica.Colocados sob a "proteção" de administradores nomeados, os índios não deveriam ser considerados legalmente escravos, nem tampouco alienáveis e transmissíveis por herança. Mas tudo isso foi derrogado pelos subterfúgios dos administradores. Da forma incompleta de escravidão indígena, a escravização transitou para a forma completa. A escravização de fato dos índios colocados sob administração particular vai sendo acobertada nos testamentos e inventários sob sucessivos eufemismos : serviços forros, gente forra, serviços alvidrados. Tais rotulações legalizavam a posse dos índios e sua transmissão hereditária. Com o tempo, a infração da lei se tornou mais descarada e os índios de administrados foram avaliados judicialmente, arrematados, hipotecados e vendidos.Estava consumada a transição da escravidão incompleta para a completa.

O problema das reduções jesuíticas[ou dos aldeamentos por outros religiosos] apenas encobriram uma estrutura econômica de finalidade mercantil, baseada numa forma de escravidão incompleta. ${ }^{2}$

Com relação a falta de mantimentos e a conseqüente carestia, não eram fenômenos particulares de São Paulo, não podendo, assim, ser indicativos da pobreza do planalto. Ao contrário, reflexo do contexto inflacionário gerado pelas minas, encontramos queixas semelhantes em outras capitanias, inclusive na área mineratória.

Assim, novos e velhos caminhos entrecruzavam-se na região paulista, articulando gêneros alimentícios, gado, mercadorias importadas, [escravos indígenas] abastecendo tanto a região do planalto, [Vale do Paraíba] como os territórios auríferos das Minas Gerais e de Cuiabá. Com a expansão da teia mercantil paulistana, os arrendamentos dos contratos e dos direitos de passagem tornaram-se cada vez mais rentáveis, sendo monopolizados nas mãos da elite local. ${ }^{3}$

Percebe-se toda uma defesa dos privilégios por parte de nossas elites coloniais, a cristalização de uma ordem estamental-escravista quase que impermeável a possíveis transformações,a eventuais quebras e brechas. Código de honra, "viver à lei da nobreza", vestimentas e formas de tratamento diferenciadas, pertencer às confrarias e ordens terceiras, ser cavaleiro da Ordem de Cristo, participar da Câmara Municipal e do juizado dos órfãos, ser capitão dos regimentos de terços, ser enterrado na igreja de

2 Jacob Gorender, O escravismo colonial,p.498-508

3 Ilana Blaj,op.cit.p.276 
São Francisco, na do Carmo ou na dos jesuítas são aspirações e comportamentos inerentes aos membros das elites senhoriais que, "como árbitros do gosto e do estilo e detentores do poder, dominaram as instituições sociais e políticas da colônia". ${ }^{4}$

Assim, escravos, terras, dignidade, honrarias e prestígio constituíam os fundamentos da sociedade colonial brasileira. Fosse nas áreas exportadoras, fosse nas de abastecimento interno, como São Paulo colonial [e a vila de Taubaté colonial], cristalizou-se uma sociedade na qual uma elite detinha a terra, os escravos e o monopólio da dominação estamental, preservando, dessa maneira, a própria ordem.

Era a ordem do Império Português, que atendia tanto à Coroa quanto às elites locais; era o fortalecimento do Estado patrimonialista, da elite senhorial dentre de um quadro estamental-escravista. Não havia antagonismos estruturais, não havia rupturas: mas inúmeros interesses em comum. ${ }^{5}$

Esta mercantilização favorecerá a transformação dos sertões do Vale do Paraíba, ampliando seus caminhos, gerando núcleos de abastecimento para as armações vindas de São Paulo em direção a região mineradora. Toda esta dinâmica fixará famílias que a mando dos donatários exploraram a região apresando e exterminando tribos inteiras.

4 Stuart B. Schwartz, Segredos internos. Engenhos e escravos na sociedade colonial, p.218. 


\section{A NEXO}

\section{LISTA DE TESTAMENTOS E INVENTÁRIOS}

Arquivo Histórico da Divisão de Museus de Taubaté

Acervo Dr. Félix Guisar Filho - século XVII

\begin{tabular}{|c|c|c|c|}
\hline Data & Testador (a) & Inventariado(a) & Cônjuge \\
\hline 1649 & & Dionízia de Góis & \\
\hline 1650 & & Estevão da Cunha & Serafina de Alvarenga \\
\hline 1651 & Jorge Lopes & Jorge Lopes & \\
\hline 1653 & & João do Prado Martins & Maria Lemme \\
\hline 1655 & Francisca Cardoza & Francisca Cardoza & Manoel Costa Cabral \\
\hline 1656 & & Violante de Siqueira & Pedro Gil \\
\hline 1657 & Maria Delgada & Maria Delgada & Braz Gonçalves \\
\hline 1658 & Anna Rodrigues & Anna Rodrigues & Batista Gago \\
\hline 1659 & Joseph de Paris & Joseph de Paris & Izabel Fernandes \\
\hline 1659 & Cap.Manoel Costa Cabral & Cap.Manoel Costa Cabral & $\begin{array}{l}1^{\mathrm{a}} \text { Francisca Cardoza/ } 2^{\mathrm{a}} \\
\text { Maria Vaz }\end{array}$ \\
\hline 1660 & Cap.Domingos Dias Félix & Cap.Domingos Dias Félix & Susana de Góis \\
\hline 1660 & & Francisco de Morais & Francisca Luiz \\
\hline 1660 & & Custódio Dias de Macedo & $\begin{array}{l}\text { Catharina Lopes de } \\
\text { Sampaio }\end{array}$ \\
\hline 1660 & Manoel Monteiro Bezerra & Manoel Monteiro Bezerra & Mécia Ribeiro \\
\hline 1660 & & João Martins & Izabel Rodrigues \\
\hline 1660 & & Manoel Coelho de Souza & Anna Costa de Albernaz \\
\hline 1660 & João Lopes Gil & João Lopes Gil & Catherina Cabreira \\
\hline 1660 & Domingos Pires Valadão & Domingos Pires Valadão & Antonia da Cunha \\
\hline 1661 & & Maria da Luz de Camargo & Grizostimo Fernandes Preto \\
\hline 1661 & & Catharina Dias & Domingos do Prado Martins \\
\hline 1661 & João Azeredo Coutinho & João Azeredo Coutinho & Ignes Montera \\
\hline 1662 & & Antonio Gonçalves & Maria Gonçalves \\
\hline 1663 & & Antonio de Faria Albernaz & $\begin{array}{l}1^{\mathrm{a}} \text { Catarina de Sisneira / } 2^{\mathrm{a}} \\
\text { Marina de Lara }\end{array}$ \\
\hline 1663 & Francisca Luis & Francisca Luiz & João Teixeira \\
\hline 1664 & Antonio Rodrigues & Antonio Rodrigues & Catherina da Costa \\
\hline 1664 & Jorge da Costa & Jorge da Costa & \\
\hline 1664 & Antonio Ribeiro & Antonio Ribeiro & Anna Cardoza \\
\hline 1665 & & Luis Fernandes de Moura & Anna Rodrigues \\
\hline
\end{tabular}




\begin{tabular}{|c|c|c|c|}
\hline 1666 & Cristóvão R. de la Penha & Cristóvão R. de la Penha & Ignes Rodrigues Morais \\
\hline 1667 & Miguel Fernandes Edra & Miguel Fernandes Edra & \\
\hline 1667 & Catherina da Costa & Catherina da Costa & Antonio Rodrigues \\
\hline 1668 & Miguel de Góis & Miguel de Góis & Maria Borges \\
\hline 1668 & Sebastião G. de Barros & Sebastião G. de Barros & Illena Torres \\
\hline 1668 & Cap. Pedro Gil & Cap. Pedro Gil & $\begin{array}{l}1^{\mathrm{a}} \text { Violante de Siqueira / } \\
2^{\mathrm{a}} \text { Izabel da Cunha }\end{array}$ \\
\hline 1669 & Izabel de Araujo & Izabel de Araujo & Antonio de Barros Frere \\
\hline 1670 & Paulla Fernandes & Paulla Fernandes & Antonio Luis Carneiro \\
\hline 1670 & João Correa & João Correa & Catherina Sisneira \\
\hline 1670 & Dominguos Fernandes & Dominguos Fernandes & \\
\hline 1671 & Domingos G. da Costa & Domingos G. da Costa & Ynnes de Góis \\
\hline 1671 & Sebastiana de Torres & Sebastiana de Torres & Manoel de Figueiredo \\
\hline 1671 & & João Luis & Inocência Rodrigues \\
\hline 1671 & & Francisco Botelho & Izabel Rodrigues \\
\hline 1672 & & Joanna Ramalho & Damião de Morais \\
\hline 1672 & Francisco dos Anjos & Francisco dos Anjos & Ursula da Cunha \\
\hline 1672 & Bernarda R. do Prado & Bernarda R. do Prado & Luiz Coelho de Sá Costa \\
\hline 1672 & Henrique da Cunha Lobo & Henrique da Cunha Lobo & \\
\hline 1672 & Pe. Antonio R. do Prado & Pe. Antonio R. do Prado & \\
\hline 1672 & Antonia Furtada & Antonia Furtada & Francisco Rodrigues \\
\hline 1673 & & Manoel C. de Andrade & Mariana Rodrigues \\
\hline 1673 & & Sebastião Luis & Izabel do Prado \\
\hline 1673 & & Lourenço da Veiga & Ana de Proença \\
\hline 1673 & & Antonio Timudo & Maria Rodrigues \\
\hline 1674 & Antonio Vieira da Maya & Antonio Vieira da Maya & $\begin{array}{l}1^{\mathrm{a}} \text { Izabel da Cunha/ } \\
2^{\mathrm{a}} \text { Maria Cardoza }\end{array}$ \\
\hline 1674 & & Luis de Souza Ferreira & Anna Rodrigues \\
\hline 1675 & Maria Moreira & Maria Moreira & Manoel Vieira Sarmento \\
\hline 1676 & $\begin{array}{l}\text { Domingos Arenço } \\
\text { Botelho }\end{array}$ & Domingos Arenço Botelho & Ana Ribeira de Escobar \\
\hline 1677 & Pedro Aranha & Pedro Aranha & Maria Dias Botelho \\
\hline 1678 & & Antonio Teixeira Side & \\
\hline 1678 & & Francisco Martins Farel & Leonor Rodrigues \\
\hline 1678 & & João da Costa & \\
\hline 1680 & & Alberto Lobo Louzada & Catherina de Góis \\
\hline 1680 & Manoel Borges Conseiro & Manoel Borges Conseiro & \\
\hline 1680 & & João Pereira Quaresma & $\begin{array}{l}\text { Ana Maria Luis. de } \\
\text { Camargo }\end{array}$ \\
\hline 1680 & & Margarida da Costa & \\
\hline 1681 & Bernardo Bonfillio & Bernardo Bonfillio & Maria da Assunção \\
\hline 1681 & Antonio Antunes Barboza & Antonio Antunes Barboza & Maria da Silva \\
\hline
\end{tabular}




\begin{tabular}{|c|c|c|c|}
\hline 1682 & & Antonio Lourenço & Maria Luis \\
\hline 1682 & & André Fernandes Urtunha & Maria da Cunha \\
\hline 1683 & Mariana de Camargo & Mariana de Camargo & Francisco Cardozo \\
\hline 1683 & Izabel da Cunha & Izabel da Cunha & Pedro Gil \\
\hline 1683 & & Sebastião Gil (o moço) & Elena Rodrigues \\
\hline 1683 & Antonio Rodrigues & Antonio Rodrigues & Izabel Cardoza \\
\hline 1684 & José de Castilho(Moreira) & José de Castilho(Moreira) & Izabel Fragosa \\
\hline 1684 & & Francisco G. Delgado & Maria das Neves \\
\hline 1684 & Antonio Rapozo Barreto & Antonio Rapozo Barreto & Maria de Britto \\
\hline 1684 & Francisco Gil de Siqueira & Francisco Gil de Siqueira & Juana Garcia do Prado \\
\hline 1684 & João Vieira da Maia & João Vieira da Maia & Catharina Rodrigues \\
\hline 1684 & & Domingas Ribeira & Lucas Fernandes Pinto \\
\hline 1684 & Ignácio de Camargo & Ignácio de Camargo & \\
\hline 1684 & Paulla Cunha & Paulla Cunha & $\begin{array}{l}\text { Bernardo Sanches de la } \\
\text { Pimenta }\end{array}$ \\
\hline 1685 & Potência Leite & & Antonio Rove Miranda \\
\hline 1685 & Amaro Gil & Amaro Gil & Mariana de Freitas \\
\hline 1685 & $\begin{array}{l}\text { Bertholomeu da Cunha } \\
\text { Gago }\end{array}$ & $\begin{array}{l}\text { Bertholomeu da Cunha } \\
\text { Gago }\end{array}$ & Maria Portes del Rei \\
\hline 1685 & Jose Cubas Rapozo & Jose Cubas Rapozo & \\
\hline 1685 & $\begin{array}{l}\text { Francisco } \quad \text { Borges } \\
\text { Rodrigues }\end{array}$ & Francisco Borges Rodrigues & Luzia Rodrigues do Prado \\
\hline 1685 & Paulla F. de Oliveira & Paulla F. de Oliveira & Antonio Gil \\
\hline 1686 & & Margarida Bicuda & Inocêncio Correa \\
\hline 1686 & & Belchior da Cunha & \\
\hline 1686 & Catherina Nunes & Catherina Nunes & Thomas Romeiro \\
\hline 1687 & Sebastião Martins Pereira & & Maria Cunha Costa \\
\hline 1687 & Catherina Portes del Rey & Catherina Portes del Rey & Simão da Cunha Gago \\
\hline 1687 & Maria Fragosa & Maria Fragosa & Cel.Sebastião de Freitas \\
\hline 1687 & & Helena Rodrigues & Manoel Garcia Velho \\
\hline 1687 & $\begin{array}{l}\text { Miguel de Almeida } \\
\text { Cunha }\end{array}$ & Miguel de Almeida Cunha & Maria Vieira \\
\hline 1687 & Francisco Pedrozo & Francisco Pedrozo & Anna Fernandes \\
\hline 1688 & Catherina Dias da Luz & Catherina Dias da Luz & Manoel Lopes Fernandes \\
\hline 1688 & Pascoal Gil & Pascoal Gil & Maria da Silva \\
\hline 1688 & & Maria de Oliveira & Antonio Jorge \\
\hline 1689 & & Martha de Miranda & Francisco Cubas Preto \\
\hline 1689 & & José de Oliveira & Maria de Madureira \\
\hline 1691 & & João Pedrozo & Maria Cardoza \\
\hline 1691 & Salvador Gil de Siqueira & Salvador Gil de Siqueira & Marina de Chaves \\
\hline 1692 & & $\begin{array}{llll}\text { Anna Vaz Cardoza da } & \text { da } \\
\text { Cunha } & & & \end{array}$ & $\begin{array}{l}\text { Antonio de Siqueira de } \\
\text { Escobar }\end{array}$ \\
\hline
\end{tabular}




\begin{tabular}{|c|c|c|c|}
\hline 1692 & Domingas Lobo & Domingas Lobo & João Delgado de Escobar \\
\hline 1692 & & $\begin{array}{l}\text { Antonio de Madureira } \\
\text { Moraes }\end{array}$ & Joana Cordeira \\
\hline 1692 & Antonio da Costa Gil & Antonio da Costa Gil & Maria da Luz \\
\hline 1693 & & Manoel Gil Cubas & Maria Moreira \\
\hline 1693 & Maria Ribeiro & Maria Ribeiro & João R. de Pedralves \\
\hline 1694 & Pascoal Dias Furtado & & Maria Ribeira \\
\hline 1694 & & $\begin{array}{l}\text { Antonio de Siqueira (de } \\
\text { Escobar) }\end{array}$ & \\
\hline 1695 & Manoel Gil de Siqueira & Manoel Gil de Siqueira & Maria Ignes Dias Félix \\
\hline 1696 & Francisco Farel & Francisco Farel & $\begin{array}{lll}\text { Marina } & \text { Ribeira de } \\
\text { Alvarenga } & & \end{array}$ \\
\hline 1696 & & Manuel Nunes Pereira & Maria Rapoza Barbosa \\
\hline 1696 & & João Barbosa Correa & $\begin{array}{l}\text { Marta de Miranda (filha de } \\
\text { Jorge Dias Velho) }\end{array}$ \\
\hline 1696 & & José Gonçalves & Joana do Prado \\
\hline 1696 & & Manoel de Figueiredo & Catherina de Freitas \\
\hline 1697 & & Domingos Martins do Prado & Felipa Gaga Leme \\
\hline 1697 & $\begin{array}{ll}\text { Francisco } & \text { Coelho } \\
\text { deAbreu } & \end{array}$ & Francisco Coelho de Abreu & Violante de Siqueira \\
\hline 1697 & & Maria Borges & \\
\hline 1697 & & João Pereira Xiberia & Antonia Furtada \\
\hline 1697 & & Francisco Correa da Veiga & Marta de Miranda \\
\hline 1698 & & Clemente Vieira & Marianna Alves de Souza \\
\hline 1698 & Cap.Bento Gil de Siqueira & & Maria da Luz \\
\hline 1698 & & João Tavares & Anna Morais de Siqueira \\
\hline 1698 & & Manoel Paes Cordero & Ângela da Fonseca \\
\hline 1698 & Ignes Gonçalves Gil & Ignes Gonçalves Gil & $\begin{array}{l}\text { Antonio Delgado de } \\
\text { Escobar }\end{array}$ \\
\hline 1699 & Cornélio da Rocha & Cornélio da Rocha & Maria Lemme \\
\hline 1699 & Antonio Gil & Antonio Gil & Paula F. de Oliveira \\
\hline 1699 & Ignes Gonçalves & Ignes Gonçalves & \\
\hline 1699 & Diogo Teixeira da Cunha & Diogo Teixeira da Cunha & Maria Antunes da Veiga \\
\hline
\end{tabular}




\section{FONTES E BIBLIOGRAFIA}

\section{FONTES}

\subsection{MANUSCRITAS}

\section{Arquivo Histórico Ultramarino}

a partir dos catálogos do Projeto Resgate "Barão do Rio Branco" no que se refere à Capitania de São Paulo (AHU)

AHU_ACL_CU_BRASIL-SÃO PAULO

AHU_ACL_CU_023,Cx.1,D.1-90,1644-1729

1644, Junho,10,Lisboa AHU_ACL_CU_023,Cx.1,D.3

ALVARÁ do rei D. João IV ordenando que minas de ouro e prata, já descobertas ou as por descobrir, passem a ser propriedade dos vassalos que as achem, desde que paguem os devidos quintos e se submetam ao Regimento, passado ao [superintendente-geral das Minas do Brasil], Salvador Correia de Sá e Benevides, para administrar as Minas de São Paulo e São Vicente.

1681,Novembro,5,Lisboa AHU_ACL_CU_023,Cx.1,D.12

CONSULTA do Conselho Ultramarino ao príncipe regente D.Pedro sobre o requerimento do conde da Ilha do Príncipe e descendente de Martim Afonso de Sousa, primeiro donatário da Capitania de São Vicente, Francisco Luís Carneiro e Sousa, solicitando confirmação da postila da doação de umas terras na parte Sul do Estado do Brasil.

1682,Fevereiro,5,Lisboa AHU_ACL_CU_023,Cx.1,D.13

CONSULTA do Conselho Ultramarino ao príncipe regente D.Pedro sobre a disputa entre o conde da Ilha do Príncipe, [Francisco Luís Carneiro e Sousa] e o marquês de Cascais, [D.Luís Álvares de Castro Noronha Sousa e Ataíde] no tocante aos direitos e à posse da capitania de São Vicente, parecendo ao Conselho que o conde deve recorrer à justiça ordinária para resolver a questão.

1702,Julho,15,Lisboa AHU_ACL_CU_023,Cx.1,D.15

PARECER do Conselho Ultramarino sobre os atrozes crimes cometidos por falta de justiça na Capitania de São Paulo e nas Capitanias do Sul.

1714, Novembro,5, Lisboa AHU_ACL_CU_023,Cx1,D.24

CONSULTA do Conselho Ultramarino ao rei D.João V sobre os protestos e insultos de populares contra o juiz e os oficiais da Justiça, por causa de um assassinato ocorrido na Villa de Taubaté.

AHU_ACL_CU_BRASIL-SÃO PAULO_MENDES GOUVEIA

AHU_ACL_CU_023-01,Cx.1,D.1618-1714

1624,Fevereiro,9 AHU_ACL_CU_023-01,Cx.1,D.3 
DEVASSA (traslado do traslado da) que o superintendente nas matérias de guerra da Costa Sul e da Vila de São Paulo da Capitania de São Vicente e Administração Geral das Minas, Martim de Sá, mandou fazer sobre a morte do índio principal, Timacauna por Pombeiros dos brancos [índios do povoado especializados no apresamento de índios do sertão] quando este se dirigia aquela vila, com toda a sua gente, para se converter à religião católica.

1644, Lisboa AHU_ACL_CU_023-01,Cx.1,D.11

REQUERIMENTO (minuta do) dado por (D.João IV), ao general da frota que vai para a Bahia, Salvador Correia de Sá e Benevides, para o entabolamento das minas de São Paulo, recomendando que tendo feito tudo como convém, deixe "correndo" com estas Duarte Correia Vasqueanes. O monarca manda: que Salvador Correia de Sá e Benevides tenha o mesmo poder, jurisdição e alçada que tem o Governador Geral do Estado (do Brasil), nos assuntos de Justiça, Fazenda e Guerra, em toda a repartição do sul (...) que haja nas ditas minas um Provedor da Fazenda, um Tesoureiro e um Escrivão, fixando os seus ordenados; (...) que para o trabalho das mesmas minas se possa servir dos índios de qualquer aldeia, pagando-lhes os seus salários. Diz ainda que, tendo sido informado de não só em São Paulo, mas também em outras partes do Brasil, haver minas de ouro, prata, ferro,cobre, calaim, pérolas e esmeraldas, o encarrega de tomar informações delas e procurar descobrilas. Manda que agracie com honras, mercês todas as pessoas que descobrirem minas, para assim as estimular.Recomenda particular cuidado com o descaminho do que pertencer aquela Fazenda,(...). Diz que só em São Paulo se construa uma Casa da Moeda, com os oficiais necessários.

1647, Fevereiro,21,Lisboa AHU_ACL_CU_023-01,Cx.1,D.14

CONSULTA do Conselho Ultramarino, sobre as cartas que escreveram, à (D.João IV), o Governador Geral do Estado do Brasil, o governador e oficiais da Câmara do Rio de Janeiro e das Vilas de São Paulo,São Vicente, Conceição e Parnaíba, acerca dos religiosos da Companhia (de Jesus), daquelas partes. (...) O Conselho conforma-se em tudo com o parecer de Salvador Correia de Sá e Benevides exceto no fato da administração dos índios ser retirada aos religiosos da Companhia.

1653, Julho,8,Santos AHU_ACL_CU_023-01,Cx.1,D.17

CARTA do (administrador das minas do sul), Pedro de Sousa Pereira, para D.João IV, em que dá conta do mau procedimento dos descobridores de minas, capitão da gente, Domingos Leite, Padre Frei Belchior de São Francisco e Antonio Nunes Pinto enviados à descoberta de pedras de prata.

1657,Junho,4,Santos AHU_ACL_CU_023-01,Cx.1,D.22

CARTA do Provedor e Contador da Fazenda Real e Juiz da Alfândega nas Capitanias de São Vicente,Sebastião Fernandes Correia, para D.Afonso VI, avisando-o de algumas coisas que naquelas capitanias se fazem contra o serviço real e de Deus. (...) Há muitas desordens principalmente na Vila de São Paulo, onde se não faz justiça, pois a geração a quem chamam de Camargo unida com a de João Pires, todos naturais da dita vila, tem na sua mão os Juízes e Oficiais da Câmara, e livram assim todo o criminoso que a eles se juntam.

[ant.1679,Abril,9] AHU_ACL_CU_023-01,Cx.1,D.24

REQUERIMENTO do conde da Ilha do Príncipe, por seu procurador, Luís Lopes de Carvalho, ao Provedor e Contador da Fazenda Real da Capitania de São Vicente, capitão Pablo Rodrigues de Lara, pedindo uma certidão em que conste que Martim Afonso de Sousa, seu filho Pedro Lopes de Sousa, seu neto Lopo de Sousa e sua neta D. Mariana de Sousa, Condessa de Vimieiro, foram donatários e governadores da referida capitania noeando nela os capitães e ouvidores, os quais concederam sempre terras de sesmaria aos moradores dela. 
1668,Janeiro,28, Lisboa AHU_ACL_CU_023-01,Cx.1,D.25

CONSULTA do Conselho Ultramarino, sobre a carta do licenciado Clemente Martins de Matos para o (Príncipe Regente D.Pedro), dizendo que o administrador das minas de Paranaguá e Governador da Gente de Guerra, Agostinho Barbalho Bezerra, tendo reconhecido a utilidade que haveria de o deixar acompanhar no descobrimento daquelas minas, lhe perdoara os crimes de rapto de uma filha de Leornardo Correia e da morte de Francisco Saraiva e pedindo-lhe que mande confirmar este perdão, para que possa continuar no descobrimento das minas. Pareceu ao Conselho que, vista a forma de provisão que (Príncipe Regente D.Pedro) concedeu a Agostinho Barbalho Bezerra, para poder perdoar os crimes a pessoas que fossem úteis, para o descobrimento das minas, sem exceção da sua qualidade, se deve mandar libertar o suplicante.

1673, Junho,28, Lisboa AHU_ACL_CU_023-01,Cx.1,D.27

REGIMENTO (traslado do) dado pelo Príncipe Regente (D.Pedro), ao Administrador e Provedor das minas de prata, D. Rodrigo de Castelo Branco, para este usar no entabolamento das minas de prata de Tabaiana e Serra de "Sabarabussu" do Estado do Brasil. (...) Ordena-se-lhe mais o seguinte: levar material que julgar necessário e nomear um Tesoureiro e um Escrivão para assentarem tudo o que levarem e as despesas que fizeram para quais receberá o rendimento das baleias da Bahia; empregar no trabalho das minas os índios e mestiços e também os índios que não estiverem domesticados, e que procurará persuadir, com bons modos, ao trabalho, pagando a todos como é costume e pontualmente;(...) se necessitar de soldados para a guarnição das minas, que podem ser atacadas pelo "gentio bravio", pedi-los ao Governador Geral (do Estado do Brasil) e ao da Capitania mais próxima do lugar atacado.

\section{Arquivo da Arquidiocese de São Sebastião do Rio de Janeiro}

Fraternidade Franciscana de Santo Antonio - Província da Imaculada Conceição

Fundação do Convento de Santa Clara / Livro do Tombo G, I, fl. 9v

Moradores faltam compromisso e frei Jerônimo apresenta queixa ao vigário da Vara o licenciado Mateus Nunes de Siqueira, residente em São Paulo - Carta Monitória / Tombo T, fl. 3v

Carta lida publicamente intimada aos Juízes conforme certidão 15/mar/1677 / Tombo T,fl 4 e 4v

Imagens de São Francisco, São Domingos e N.Sra. Piedade (1757 foi distinguida com indulgências). / Tombo T, fl. 33v

Ordem Terceira ( 1720) / Tombo T, fl. $21 \mathrm{v}$

Escritura da doação do primeiro terreno - 1674 - Cap. Sarmento / Certidão no Arquivo da Província pág. 22

Doação do Príncipe Regente de $40 \$ 000$ por provisão 22/fev/1677 / Tombo G, I, fl. $7 \mathrm{v}-$ Ord. Reg. fl.2

Portaria 14/jul/1677 / Ordem Príncipe Regente para que as Aldeias dos índios fossem administradas por religiosos e não seculares. Ordem renovada em carta 17/jan/1691 / Tombo G, I, fl. 91

Justificativa por nossa Província possuir mais missionários que falavam a língua indígena. / Tombo G, I, fl. 89 v

Em Taubaté os índios viviam dispersos e convinha aldeá-los. / Tombo Itanh., fl. 26 
Capitão-mor Martim Garcia Lumbria expede autorização para a administração dos índios aos religiosos. / Tombo T, fl. 4v

Epítome de frei Apolinário - 1730 / Havia no Convento de Santa Clara "alguns confessores da língua da terra para confessar o gentio dela". / Epítome, Parágrafo 22 - Primazia, cap.14, p.173.

Petição e carta de sesmaria ao Capitão-mor e goverrnador Antonio Caetano Pinto Coelho, renovação da doação - Certidão em 08/nov/1802 Arquivo da Província. / Porcos e Escravos do Convento

Proibição de negociar porcos com os escravos índios do Convento, visto que eram doações. / Tombo T, fl. 22v

Aulas no Convento / Aulas de primeiras letras e gramática para meninos nos Conventos - 1730 / Três conventos : Cabo Frio, Macacu e Taubaté" / Frei Apolinário, Epítome, Parágrafo 22 / Reg. Rel. Europ., I, fl. 85

Os escravos do Convento / Missas por alma de escravos falecidos. / Frei Basílio, O Convento, 3 ed. Pág. 77 e seg.

\section{Divisão de Museus, Patrimônio e Arquivo Histórico de Taubaté (DMPAH)}

Atas da Câmara de Taubaté (1780-1798), v. I , Empresa Editora Universal, São Paulo, 1943. (Não encontramos nenhum outro registro anterior a este período). Documentos para a História do Vale do Paraíba publicado por Felix Guisard Filho

Carta de Alforria, feita a requerimento de Marcela, negra do gentio da terra, serviço de Francisco Rodrigues Moreira em 22/nov/1698 na Vila de São Francisco das Chagas de Taubaté

Livro de Registros e Escrituras - período 1692 a 1700 - Bloco V - 1698-1700

Carta de Alforria, digo Declaração que faz Manoel Fernandes Urtunho e sua mulher Domingas do Prado. 01/dez/1698 na Vila de São Francisco das Chagas de Taubaté.

Livro de Registros e Escrituras - período 1692 a 1700 - Bloco V - 1698-1700

Registros de Batismos 1686 / Caixa 02 doc. 032

Inventários e Testamentos Seiscentistas (Listagem no Anexo)

Acervo Dr. Félix Guisar Filho - século XVII

Caixa 1 - 1649 - 1677 (Doc. 1-58)

Caixa 2 - 1678 - 1689 (Doc.1-46)

Caixa 3 - 1691 - 1699 (doc.1-33)

São 76 Testamentos e 126 Inventários post-mortem da Vila de São Francisco das Chagas de Taubaté do século XVII.

\subsection{Impressas}

ATAS DA CÂMARA da Villa de São Paulo 1623-1628, volume III, São Paulo, Duprat \& Cia., 1915

ATAS DA CÂMARA da Villa de São Paulo 1629-1639, volume IV, São Paulo , Duprat \& Cia., 1915 
ATAS DA CÂMARA da Villa de São Paulo 1640-1652, volume V, São Paulo, Typographia Piratininga, 1915

ANDREONI, João Antonio (Antonil). Cultura e opulência do Brasil por suas drogas e Minas (1711). 2ed.São Paulo. Editora Nacional,1966.

GANDAVO, Pero de Magalhães. Tratado da terra do Brasil; História da Província Santa Cruz (1570-1576). Belo Horizonte:Itatiaia,São Paulo:Edusp, 1980.

KNIVET, Anthony, Notável viagem que no anode 1591 e seguintes, fez Antonio Knivet da Inglaterra ao mar do Sul, em companhia de Thomaz Candish. Tradução do holandês de J. H. Duarte Pereira. In: Revista do Instituto Histórico e Geográfico Brasileiro, tomo XLI, p.1. Tipografia Pinheiro \& Cia, Rio de Janeiro, 1878.

LEITE, Serafim. Cartas dos Primeiros Jesuitas no Brasil, vol.I , 1538-1553. Comissão do IV Centenário de São Paulo, São Paulo, 1956.

LEME, Pedro Taques de Almeida Paes. História da Capitania de São Vicente (1714-1777). São Paulo, Melhoramentos, 1914

MADRE DE DEUS, Frei Gaspar da. Memórias para a história da capitania de São Vicente (1797). Belo Horizonte: Itatiaia, São Paulo: Edusp,1975.

ORDENAÇÕES FILIPINAS. In: ALMEIDA, Cândido Mendes de. Auxiliar Jurídico - Legislação Brasileira Antiga e Moderna.Rio de Janeiro,1869.

SALVADOR, Frei Vicente do. Historia do Brasil (1500-1627), 7 ed., Belo Horizonte: Itatiaia, São Paulo : Edusp,1982.

SOUSA, Gabriel Soares de. Tratado Descritivo do Brasil em 1587, 5 ed.,São Paulo: Nacional, Brasília:INL,1987.

VASCONCELOS, Simão de. Vida do Padre João de Almeida. Lisboa, Editora A.J.Fernandes Lopes, 1658

\section{BIBLIOGRAFIA}

\subsection{DICIONÁRIOS}

AZEVEDO, Antonio Carlos do Amaral. Dicionário de nomes, termos e conceitos históricos, $3^{\mathrm{a}}$ edição ampl. e atualizada, Rio de Janeiro, Nova Fronteira,1999.

BALLESTERO, Maria Esmeralda; BALBÁS, Alvarez Marcial Soto. Dicionário Espanhol-Português e Português-Espanhol, São Paulo, FTD, s/d.

BOTELHO, Ângela Vianna. Dicionário Histórico Brasil: Colônia e Império, $4^{\mathrm{a}}$ edição, Belo Horizonte, Autêntica, 2003.

FERREIRA, Aurélio Buarque de Holanda. Novo Dicionário da Língua Portuguesa, $2^{a}$ edição, Rio de Janeiro, Editora Nova Fronteira, 1986.

FRANCO, Francisco de Assis Carvalho. Dicionário de bandeirantes e sertanistas do Brasil. São Paulo, Comissão do V Centenário da Cidade de São Paulo,1954. 
MARQUES, Manuel Eufrásio de Azevedo. Apontamentos da Província de São Paulo, tomo I, São Paulo, Livraria Martins editora, 1952 (Coleção Biblioteca Histórica Paulista)

MONTEIRO,John M. (org.) Guia de fontes para a História Indígena e do Indigenismo. São Paulo, NHII - USP/FAPESP,1994.

SILVA, Antonio de Moraes. Diccionário de Língua Portuguesa. Fac-Símile da segunda edição (1813), Rio de Janeiro, Officinas da S.A. Litho-Typographia Fluminense, 1922

\subsection{LIVROS E TESES}

ABREU, João Capistrano de. Capítulos de História Colonial (1500-1800),6 ed., Rio de Janeiro,Civilização Brasileira; Brasília,INL,1976.

Caminhos antigos e povoamento do Brasil, 2 ed., Rio de Janeiro:Briguiet,

1960.

ABREU, Maria Morgado de. Taubaté, de núcleo irradiador de bandeirismo a centro industrial e universitário do Vale do Paraíba. Aparecida-SP, Editora Santuário,1985.

; ANDRADE, Antonio Carlos de Argôllo. História de Taubaté através de textos. Taubaté. Gráfica e editora Minerva. 1996. (Coleção Taubatena n.17)

AB'SABER, Aziz N. Fundamentos Geográficos da História Brasileira.In: HOLLANDA, Sergio Buarque de. História Geral da Civilização Brasileira, $7^{\mathrm{a}}$ ed., Tomo I, v.1, São Paulo,Difel,1985, p.55-71.

ABUD, Kátia Maria. $O$ sangue intimorato e as nobilíssimas tradições ( a construção de um símbolo paulista : o bandeirante). Tese de Doutorado,Universidade de São Paulo,1985.

ALENCASTRO, Luiz Felipe de. O tratado dos viventes : formação do Brasil no Atlântico Sul, século XVI e XVII. São Paulo, Companhia das Letras, 2000.

ALVES, Mauricio Martins. Caminhos da pobreza: a manutenção da diferença em Taubaté (1680-1729). Taubaté,1988(Coleção Taubateana 19)

ANDRADE, Antonio Luiz Dias de. Vale do Paraíba: sistemas construtivos. Dissertação de Mestrado. Faculdade de Arquitetura e Urbanismo da Universidde de São Paulo.1984.

AZEVEDO, J. Lúcio de. Os jesuítas no Grão-Pará. Lisboa, Liv. Editora Tavares Cardoso \& Irmão, 1901.

BLAJ, Ilana. Pulsações, sangrias e sedimentação: Sérgio Buarque de Holanda e a análise da sociedade paulista no século XVII. In: NOGUEIRA, Arlinda Rocha et al. (Org.). Sérgio Buarque de Holanda. Vida e obra. São Paulo: Secretaria de Estado da Cultura; Arquivo do Estado; Universidade de São Paulo; Instituto de Estudos Brasileiros, 1988. p.81-85.

A trama das tensões : o processo de mercantilização de São Paulo Colonial (1681-1721).São Paulo. Humanitas,2002.

BOXER, Charles R. A idade do ouro do Brasil (dores de crescimento de uma sociedade colonial). São Paulo,Ed. Nacional,1963. 
Salvador de Sá e a luta pelo Brasil e Angola (1602-1686).São Paulo. Ed. Nacional.Edusp.1973.

O império colonial português (1415-1825),2 ed. Lisboa:Edições 70,1981 .

BRUNO, Ernani Silva. Viagem ao país dos paulistas. Ensaio sobre a ocupação da área vicentina e a formação de sua economia e de sua sociedade nos tempos coloniais. Rio de Janeiro, José Olympio, 1966.

.Esboço da história do povoamento de São Paulo.In : BRUNO, Ernani Silva (Org.). São Paulo: terra e povo. Porto Alegre:Globo,1967, p.1-17.

O que revelam os inventários sobre escravos e gente de serviço..Revista do Arquivo Municipal, São Paulo,v.188, p.63-70, jan-dez 1976.

CALIXTO, Benedito. Capitania de Itanhaém - Memória Histórica. In: Revista do Instituto Histórico e Geográfico de São Paulo, vol. XX. São Paulo, Tipografia do Diário Oficial, 1915.

Capitanias Paulistas. São Paulo Casa Duprat e Casa Mayença, 1927

CAMPOS, Maria Verônica Governo de Mineiros. "De como meter as Minas numa moenda e beber-lhe o caldo dourado". 1693 a 1737, São Paulo, tese de doutorado, USP, 2002.

CATHARINO, José Martins. Trabalho Índio em Terras da Vera ou Santa Cruz e do Brasil: tentativa de resgate ergonlógico. Rio de Janeiro: Salamandra, 1995.

CERTAU, Michel de. A operação historiográfica. In: A escrita da História. Rio de Janeiro. Forense-Universitária, 1982,p.65-114.

COELHO, H.V. Castro. Povoadores de São Paulo - Jacques Félix Flamengo ( adendas às primeiras gerações). Revista da ASBRAP n. 12,São Paulo, 2006

COSTA, Antonio Gilberto (org.). Cartografia da conquista do território das minas. Belo Horizonte,Ed.UFMG; Lisboa, Kapa Editorial,2004.

Os Caminhos do Ouro e a Estrada Real. Belo Horizonte, Ed.UFMG; Lisboa, Kapa Editorial, 2005.

CUNHA, Manuela Carneiro da (org.). História dos Índios no Brasil. São Paulo, Companhia das Letras, 1992.

DAVIDOFF, Carlos. Bandeirantismo : verso $e$ reverso. São Paulo:Brasiliense,1982. (Coleção tudo é História).

DERBY, Orville A. Primeiras Bandeiras Paulistas. Revista do Instituto Histórico e Geográfico de São Paulo, v.4. p.329-350. 1899.

DOMENICO, Hugo di. Toponímia e nomenclatura indígenas do município de Taubaté. Taubaté, Prefeitura de Taubaté, 1976.(Coleção Taubateana n.3).

ELLIS JR, Alfredo. Capítulos da história psicológica de São Paulo. São Paulo: Boletim da Faculdade de Filosofia, Ciências e Letras, n. 53, 1945.

. A economia paulista do século XVIII. São Paulo : Boletim da Civilização Brasileira, n.11,1950.

ELLIS, Miriam. As bandeiras na expansão geográfica do Brasil. In: HOLLANDA, Sergio Buarque de.História Geral da Civilização Brasileira,op.cit., p.273296.

FAORO, Raymundo. Os donos do poder: formação do patronato político brasileiro, 16 a ed.,volume 1 São Paulo Globo,2004. 
FARAGE, Nádia. As muralhas dos sertões : os povos indígenas no rio Branco e a colonização, São Paulo, Anpocs, Paz e Terra. 1991.

FARIA, Sheila de Castro. A Colônia em movimento. Rio de Janeiro, Nova Fronteira,1998.

FARIAS, Jackson Fergson Costa de. Honra e escravidão : um estudo de suas relações na América Portuguesa, séculos XVI-XVIII. Dissertação de Mestrado. Universidade de São Paulo, 2008.

FAUSTO, Carlos. Os índios antes do Brasil. Rio de Janeiro. Editora Jorge Zahar,2000

FERLINI,Vera Lucia Amaral. Terra,trabalho e poder. $O$ mundo dos engenhos no nordeste colonial.São Paulo, Brasiliense, 1988.

FERNANDES, Florestan. Antecedentes indígenas : organização social das tribos tupis. In: HOLLANDA,Sergio Buarque de. História Geral da Civilização Brasileira,op.cit., .p.82-84.

Caracteres rurais e urbanos na formação e desenvolvimento da cidade de São Paulo. In: Mudanças sociais no Brasil.São Paulo:Difusão Européia do Livro,1974.p.193-222.

FERREIRA, Tito Lívio. História de São Paulo. São Paulo : Biblos, 1968.

FREITAS, Afonso A. de. Os Guayanis de Piratininga. Revista do Instituto Histórico e Geográfico de São Paulo, vol.XIII, 1908. Tipografia do Diário Oficial,1911

FREITAS, Ludmila Gomide. A Câmara Municipal da Vila de São Paulo e a Escravidão Indígena no século XVII (1621-1696).Dissertação de Mestrado. Universidade de Campinas, 2006.

FREYRE, Gilberto. Casa Grande e Senzala. Rio de Janeiro, Olympio Editora,1961.

FURET, François. Oficinas da História. Lisboa: Gradiva,s.d.

GIUCCI, Guilhermo. A colonização acidental. Ciência Hoje, n.86,1992,p.19-23.

GLEZER, Raquel. Chão de terra e outros ensaios sobre São Paulo. São Paulo : Alameda, 2007.

GORENDER, Jacob. O escravismo colonial. São Paulo: Ática,1978.

GOUlART, José Alípio. Da Palmatória ao Patíbulo(Castigos de Escravos no Brasil). Rio de Janeiro, Editora Conquista - Instituto Nacional do Livro,1971.

GUISARD FILHO, Félix. Jacques Félix: achegas à história de Taubaté. São Paulo.Athena Editora, 1938 Convento de Santa Clara. São Paulo. Athena Editora,1938.

Índice de inventários e testamentos de Taubaté. São Paulo Athena Editora,1939.

Nomes, limites e brasões. Itacurussã. São Paulo, Athena Editora, 1939.

HECK, Egon e PREZIA,Benedito. Povos indígenas: terra é vida. São Paulo, Atual,1999.

HOLLANDA, Sérgio Buarque de (org.). História Geral da Civilização Brasileira. São Paulo, Difel,1968.

Raizes do Brasil, 5 ed. Rio de Janeiro : José Olympio,1969. 
Monções,2 ed. São Paulo : Alfa-Ômega,1976.

Caminhos e fronteiras. Rio de Janeiro : José Olympio, 1956.

Visão do Paraíso. Os motivos edênicos no descobrimento e colonização do Brasil.,2ed., São Paulo, Ed. Nacional, Edusp,1969.

HOORNAERT,Eduardo et alli. História da Igreja no Brasil. Petrópolis, Vozes, 1971.

JANOTTI, Maria de Lourdes Mônaco. Historiografia, uma Questão Regional? São Paulo no Período Republicano, um exemplo. In: SILVA, Marcos Antonio da. República em migalhas: história regional e local. São Paulo: Marco Zero; MCT/CNPq, 1990 p.81-101.

LAPA, José Roberto do Amaral. Economia Colonial. São Paulo, Perspectiva,1973 (Coleção Debates).

LEITE, Serafim.Os Jesuítas e os índios Maromomis na Capitania de São Vicente. Revista do Instituto Histórico e Geográfico de São Paulo,vol.XXXII,1937.

LOWIE, Robert H. The Tapuya. In: Handbook of Souf American Indians. Smithsonian Institution, vol.1, Washington, Unitede States,1946.

LUÍS, Washington. Na capitania de São Vicente. Belo Horizonte:Itatiaia;São Paulo : Edusp,1980.

MACHADO, Alcântara, Vida e morte do bandeirante. Belo Horizonte : Itatiaia, São Paulo : Edusp, 1980.

MAGALHÃES,Basílio de. Expansão geográfica do Brasil colonial. $4^{\mathrm{a}}$ ed.,São Paulo, Ed. Nacional,Brasília:INL,1978.

MANO, Marcel. Os Campos de Araraquara : um estudo de história indígena no interior paulista. Tese de Doutorado. Universidade de Campinas, 2006.

MANSUY, Andrée. Cultura e opulência do Brasil por suas drogas e minas. Texte de l'édition de 1711, traduction et commentaire critique. Paris : Institut dês Hautes Études de l'Amérique Latine, 1968.

MARANHO, Milena Fernandes. A opulência relativizada : significados econômicos e sociais dos níveis de vida dos habitantes do Planalto de Piratininga, 1648-1682. Dissertação de Mestrado.Universidade de Campinas,2000.

MARTINS, Gilberto. Taubaté nos seus primeiros tempos (aspectos de sua história colonial).Taubaté, EGETAL Empresa Gráfica Editora Taubaté Ltda, 1973

METRAUX,Alfred. The Guaitacá. In: Handbook of South American Indias. Smithsonian Institution, vol.1, Washington, United States, 1946.

MONTEIRO, John M. Tupis, Tapuias e Historiadores: Estudos de História Indígena e do Indigenismo. Campinas, tese de Livre Docência, IFCH/UNICAMP,2001.

Os guaranis e a história do Brasil meridional; séculos XVI-XVII. In: CUNHA, Manuela Carneiro da (org.). História dos índios no Brasil. São Paulo: Companhia das Letras;Secretaria Municipal da Cultura; Fapesp,1992,p.475-498.

Negros da Terra. Índios e bandeirantes nas origens de São Paulo. Companhia das Letras, 1994.

MORSE, Richard M. Formação histórica de São Paulo (de comunidade à metrópole), 2 ed., São Paulo: Difusão Européia do Livro,1970. 
MOURA, Américo Brasiliense Antunes de. Os Povoadores do Campo de Piratininga. Revista do Instituto Histórico e Geográfico de São Paulo, vol.XLVII, São Paulo, s/d(prefácio de setembro de 1950).

NAZZARI, Muriel. O desaparecimento do dote : mulheres, famílias e mudança social em São Paulo,Brasil,1600-1900 ; trad. Lólio Lourenço de Oliveira, São Paulo, Companhia das Letras, 2001.

NOVAIS, Fernando Antônio. Portugal e Brasil na crise do Antigo Sistema Colonial (1777-1808). São Paulo, Hucitec, 1979.

Colonização e sistema colonial : discussão de conceitos e perspectiva histórica. Anais do IV Simpósio Nacional dos Professores Universitários de História, São Paulo,1969.

OLIVEIRA, José Joaquim Machado de. Notícia raciocinada sobre as aldeias de índios da Província de São Paulo, desde o seu começo até a atualidade. Revista do Instituto Histórico e Geográfico Brasileiro, 8, 1846, p.204-254

ORTIZ, José Bernardo. São Francisco das Chagas de Taubaté.Origens. Livro 1.Taubaté. Prefeitura Municipal de Taubaté. 1988(Coleção Taubateana n.10).

São Francisco das Chagas de Taubaté.Taubaté Colonial.Livro 2. Taubaté, Prefeitura Municipal de Taubaté. 1996 (Coleção Taubateana n.10)

PASIN, José L. Algumas notas para a história do Vale do Paraíba. Conselho Estadual São Paulo, São Paulo,1977.

PERRONE-MOISÉS, Beatriz. Índios livres e índios escravos : os princípios da legislação indigenista.In: CUNHA, Manuela Carneiro da (org.). História dos índios no Brasil. São Paulo: Companhia das Letras; Secretaria Municipal da Cultura; Fapesp,1992,.p.115-132.

PETRONE, Pasquale. Aldeamentos paulistas.São Paulo :Edusp,1995.

PINHEIRO, Joely Aparecida Ungaretti. Conflitos entre jesuítas e colonos na América Portuguesa. (1640-1700). Tese de Doutorado. Universidade de Campinas, 2007.

PINTO, Venâncio Renato. Os útimos Carijós : escravidão indígena em Minas Gerais (1711-1725). Revista Brasileira de História, v.17, n.34, São Paulo, ANPUH,1997

PRADO, J.F. de Almeida. O regime das capitanias. In: HOLLANDA, Sergio Buarque de. História Geral da Civilização Brasileira, op.cit., p.96-107

PRADO, José Benedito; ABREU, Maria Morgado de. Aspectos geográficos do Vale do Paraíba e Município de Taubaté. Taubaté. Prefeitura de Taubaté,1995 (Coleção Taubateana n. 14)

PRADO JÚNIOR,Caio. Evolução política do Brasil e outros estudos. 9 ed. São Paulo. Brasiliense, 1975.

Formação do Brasil Contemporâneo. São Paulo, Brasiliense, 2004.

Historia econômica do Brasil, São Paulo, Brasiliense,2004.

PREZIA, Benedito A. Os indígenas do planalto paulista nas crônicas quinhentistas e seiscentistas. São Paulo, Humanitas, 2000.

;HOORNAERT, Eduardo. Esta terra tinha dono. São Paulo FTD,1995.

PROBER, Kurt. Ouro em pó e em barras (1754-1833). Catálogo-rol até 1990. Paquetá (RJ) Princeps Gráfica e Editora Ltda.1990. 
PUNTONI, Pedro. A guerra dos Bárbaros : povos indígenas e a colonização do sertão nordeste do Brasil, 1650-1720. São Paulo, Hucitec - Edusp,2002.

Tupi ou não tupi?. In: RISÉRIO, Antonio (org.). Invenção do Brasil. Salvador: Made,1997,p.49-55.

REIS, Paulo Pereira dos. O indígena do Vale do Paraíba : apontamentos históricos para o estudo dos indígenas do Vale do Paraíba Paulista e regiões circunvizinhas. São Paulo, Governo do Estado, 1979.

Lorena nos séculos XVII e XVIII. Lorena , CERED, 1988 (Cadernos culturais do Vale do Paraíba).

RENDON, José Arouche de Toledo. Memória sobre as aldeias dos índios da Província de São Paulo. Revista do Instituto Histórico e Geográfico Brasileiro, t.IV, 1863.

RODRIGUES, José Honório . História da História do Brasil, Historiografia Colonial. 2 ed., São Paulo, Ed. Nacional, 1979.

ROWER, frei Basílio, O.F.M. Páginas de História Franciscana no Brasil, Petrópolis (R.J.), Editora Vozes Ltda, 1957.

o Convento de Santo Antonio do Rio de Janeiro: sua história, memórias, tradições. Rio de Janeiro : Jorge Zahar Ed.,2008

RUGENDAS, Johan Moritz. Viagem Pitoresca através do Brasil. Tradução de Sérgio Milliet. Belo Horizonte, Itatiaia. São Paulo, EDUSP, 1989.(Coleção Reconquista do Brasil, $3^{\text {a }}$ série, v.8)

SALGADO, Graça (Coord.) Fiscais e meirinhos. A administração no Brasil colonial. Rio de Janeiro, Nova Fronteira; Brasília :INL,1985.

SAMPAIO, Theodoro. O tupi na geografia nacional. Revista do Instituto Histórico e Geográfico de São Paulo,vol.II,1896-1897

São Paulo de Piratininga no fim do século XVI. Revista do Instituto Histórico e Geográfico de São Paulo,v.4, p.257-278, 1899.

O sertão antes da conquista (século XVII). Revista do Instituto Histórico e Geográfico de São Paulo v.5, p.79-94,1901.

Peregrinações de Antonio Knivet no Brasil do século XVI, tomo especial, parte II, Imprensa Nacional, Rio de Janeiro,1915.

SCHWARTZ, Stuart B. Segredos internos. Engenhos e escravos na sociedade colonial. São Paulo. Companhia das Letras, 1988.

SILVA, Joaquim Norberto de Sousa. Memória Histórica e Documentada das Aldeias de Índios da Província do Rio de Janeiro. In: Revista do Instituto Histórico e Geográfico Brasileiro

SOUSA, Washington Luís Pereira de. Na capitania de São Vicente. Belo Horizonte, Itatiaia; São Paulo:EDUSP, 1980

SOUZA, Laura de Mello e. Desclassificados do ouro. A pobreza mineira no século XVIII. Rio de Janeiro, Graal,1982.

O diabo e a terra de Santa Cruz. São Paulo, Companhia das Letras, 1986.

Inferno Atlântico: demonologia e colonização, séculos XVI-XVIII.São Paulo. Companhia das Letras,1993.

O Sol e a Sombra: política e administração na América Portuguesa do século XVIII. São Paulo.Companhia das Letras,2006. 
SPOSITO, Fernanda. Nem cidadãos, nem brasileiros: indígenas na formação do estado nacional brasileiro e conflitos na Província de São Paulo (18221845).Dissertação de Mestrado.Universidade de São Paulo,2006

STELLA, Jorge Bertolaso. As línguas indígenas da América, separata da Revista do Instituto Histórico e Geográfico de São Paulo, vol.26,1928

STELLA, Roseli Santaella. Sobre a Capitania de São Vicente, século XVI-XVII. São Paulo: Academia Lusíada de Ciências, Letras e Artes, 1999.

TAUNAY, Affonso de Ecragnolle. História Geral das Bandeiras Paulistas, tomo IX, São Paulo, Editora Imprensa Oficial do Estado de São Paulo, 1948.

São Paulo nos primeiros anos. Ensaio de reconstituição social; São Paulo no século XVI: história da vila piratiningana. São Paulo, Paz e Terra,2003.

THOMAS, Georg. Política indigenista dos portugueses no Brasil (1500-1640). São Paulo, Loyola, 1982.

TOLEDO, Francisco de Paula. História do Município de Taubaté, $2^{\mathrm{a}}$ ed.,Taubaté, Prefeitura Municipal de Taubaté, 1976.(Coleção Taubateana n.6)

VIANNA, Oliveira. Populações meridionais do Brasil. 4 ed., São Paulo,Ed. Nacional 1938.

ZALUAR, Augusto Emílio. Peregrinação pela Província de São Paulo (18601861). Biblioteca Histórica Paulista, São Paulo, Livraria Martins Editora, 1952. 